\title{
INTERPRETAÇÃO GEOPEDOLÓGICA APLICADA A ESTUDOS DE GEOLOGIA DE ENGENHARIA
}

\author{
Fernando Ximenes de Tavares Salomão
}

Orientador: Prof. Dr. Sergio Estanislau do Amaral

DISSERTAC̣ÃO DE MESTRADO

Área de Concentracão:

Geologia Geral e de Aplicação

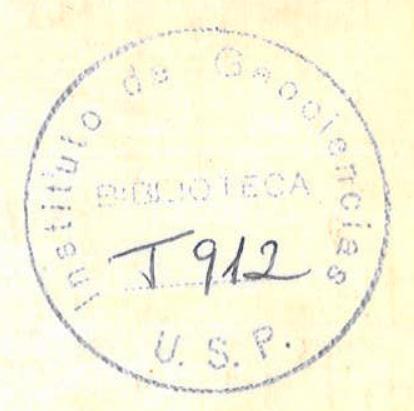

São Paulo

1984 


\section{UNIVERSIDADE DE SĀO PAULO INSTITUTO DE GEOCIENNCIAS}

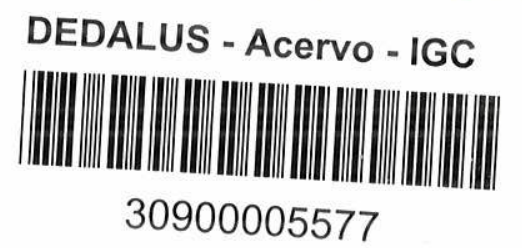

\section{INTERPRETAÇĀO GEOPEDOLÓGICA APLICADA A ESTUDOS DE GEOLOGIA DE ENGENHARIA}

Fernando Ximenes de Tavares Salomāo

Orientador: Prof. Dr. Sergio Estanislau do Amaral

COMISSĀO EXAMINADORA

nome

ass.

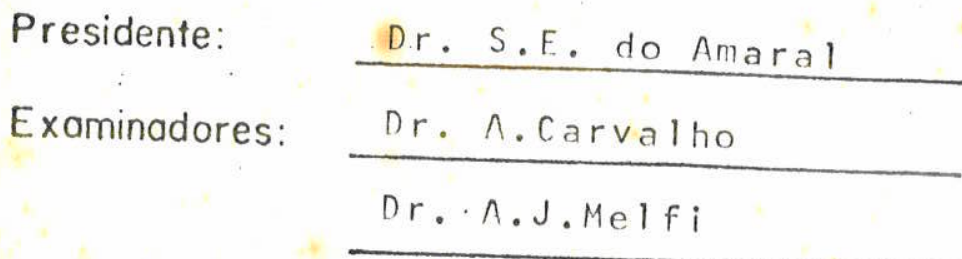

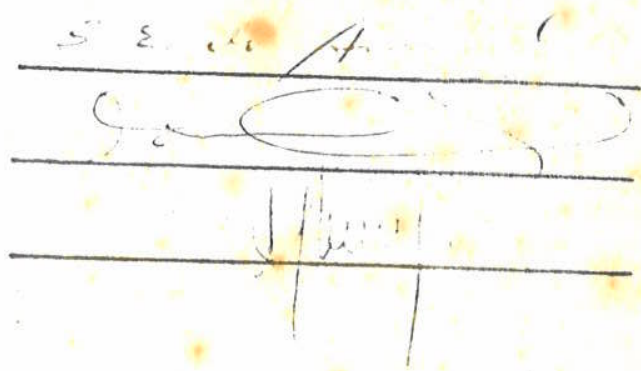


Aos técnicos do IPT que atua ram no Projeto Jaîba, durañ te os anos de 1976 a 1979 , cuja dedicasão ao trabalho em equipe, e motivacão ã pes quisa, permitiram a fundamen tasão teórica e prática, im prescindiveis para o desen volvimento deste trabalho. 


\section{ABSTRACT}

Recent Engineering Geology development in Brazi] shows the need of a retaking of the geological reasoning joined with other physical environment components in order to better accomplish its important role in Civil Engineering Works. In this way the collaboration of all sciences that act on physical environment should be searched towards Engineerinc Geolocy objectives.Synthesis methods and data integration should be developed in order to achieve those goals.

Pedology, a soil science, can significantly contri bute to Engineering Geology studies. Althoutg recent te chnical advances in this science, it has been noticed a lake of integrated studies between soil genesis and geo technical phenomena.

The present M.Sc. thesis work looks for a methodo logical proprosal applied mainly to Civil Engineering works preliminary steps.

Physical environment was studied in terms of gene tically homogeneous soil occurrences related to geote chnical needs.

The first part of the thesis presents some fundamen tal concepts for the geopedological interpretation. The second part of it presents the results of studies de veloped in the "Distrito Agroindustrial de Jaiba", the synthesis of the geopedological data interpretation and the Engineering Geology applications. 


\section{RESUMO}

O estágio atual de desenvolvimento da geologia de Engenharia no Brasil evidencia a necessidade de uma retomada do raciocinio geológico, integrado aos demais componentes do meio físico, de maneira a melhor cumprir - seu importante papel na implantação de obras de Enge nharia Civil. Neste sentido, deve-se buscar a colabora ção de todas as ciências responsăveis pelo estudo do meio físico e desenvolver métodos de sintese e de inte gração de dados, direcionados aos objetivos da Geolo gia de Engenharia.

A Pedologia, ciência responsāvel por estudo do so 10, tem muito a contribuir para a Geologia de Engenharia. Nota-se entretanto, apesar dos avanços recentes, uma 1 cuna muito grande em trabalhos de pedologia aplicada à Engenharia Civil, especialmente em se tratando das rela coões entre a gênese de solos e os fenômenos geotécnicos.

E dentro destas preocupações que se insere esta dis sertação de mestrado, procurando, em termos metodológi cos, contribuir com uma proposta a ser adotada princi palmente numa fase de estudos preliminares de obras de Engenharia Civil. Procurou-se, neste trabalho, interpre tar o meio físico de maneira a entender a distribuição de ocorrências geneticamente homogêneas de solos, orien tando essa interpretação aos interesses geotēcnicos.

Nas partes iniciais desta dissertação foram apre 
sentados alguns conceitos consiúerados fundamentais pa ra a interpretação geopedolōgica, e a seguir, uma expe riência de trabalho na região compreendida pelo Distrí to Agroindustrial do Jaíba, onde foram sintetizados os resultados da interpretação geopedolōgica, e sua aplica ção para a Geologia de Engenharia. 


\section{AGRADECIMENTOS}

Desejo expressar os meus sinceros agradecimentos a todos que direta ou indiretamente serviram de apoio à concretização deste trabalho, em especial ao Instituto de Pesquisas Tecnolōgicas do Estado de São Paulo, atravēs da Divisão de Minas e Geologia Aplicada, que, na pessoà do séu diretor, Geōt. Ricardo Fernandes da Silva, concedeu os meios necessārios para a efetivação deste trabalho.

Ao Professor Dr. Sergio Estanislau do Amaral pela orientação, revisão crītica e sugestões apresentadas a esta dissertação.

Ao Professor Dr. Adolfo Melfi pela revisão e crí ticas finais ao texto.

Aos colegas do IPT que atuaram no Projeto Jaiba, cujo trabalho em equipe permitiu a obtenção dos elemen tos fundamentais para a elaboração desta dissertação. Aos colegas. Alvaro Rodrigues dos Santos e Waldir Lopes Ponçano pelo incentivo à escolha e desenvolvimento do tema. Em especial, meus agradecimentos aos colegas An tonio Manoel dos Santos 01 iveira, Carlos Geralco Luz de Freitas, Marcos Tadeu Novaes dos Santos e Ely Borges Frazão, pelas sugestões, apreciações crĩtica e apoio du rante todo desenvolvimento do trabalho.

Aos colegas Marcio Lucio Gonzaga, Claudemir Anto nio de Paula, Alvaro Camargo Kopezynske, e desenhistas 
da DMGA pela dedicação nos trabalhos de campo, montagem e no proparo das ilustrações.

Aos coletas do setor de Documentação da DMGA, em especial, à Bibliotecária Maria Solange 0 . Pereira e Maria Inez do Prado pela ordenação das referēncias bi bliogräficas.

A Aradi Jecira da cruz, pela dedicação nos servi ços de datilografia e sugestões na apresentação do tex to final. 


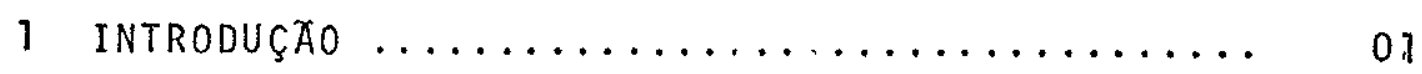

2 CONSIDERAÇOES PRELIMINARES .............. 08

2.10 Solo: Conceitos Básicos Pedogenēticos .... 08

2.2 Mëtodos de Trabalho e Materiais Empregados.. 23

2.2.1 Roteiro metodolögico geral .......... 24

2.2 .2 Documentação bäsica $\ldots \ldots \ldots \ldots \ldots \ldots \ldots \ldots$

2.2.3 Têcnicas adotadas no trabalho de campo... 28

2.2 .4 Tëcnicas de laboratōrio ............. 28

3 A INTERPRETAÇO GEOPEDOLOGICA DO DISTRITO AGRO INDUSTRIAL DO JAİBA, MUNICIPIO DE MANGA, MG... 31

3.1 Considerações Preliminares ............ 31

-3.2 0 Meio Geogräfico, Geolögico e Pedolōgico... 34

3.2 .1 clima $\ldots \ldots \ldots \ldots \ldots \ldots \ldots \ldots \ldots \ldots \ldots \ldots \ldots \ldots$

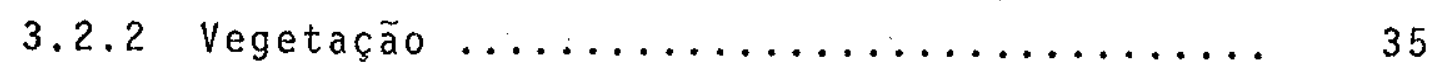

3.2 .3 Geologia ................... 36

3.2 .4 Geomorfologia ................. 41

3.2 .5 Pedologia $\ldots \ldots \ldots \ldots \ldots \ldots \ldots \ldots \ldots \ldots$

3.3 As Associações Geopedolögicas ............. 74

3.4 A Interpretação Geopedolögica $\ldots \ldots \ldots \ldots \ldots . \ldots 78$

3.4.1 Ambiente Geopedológico I: solos desenvolvi dos sobre sedimentos coluvionares ....... 80

3.4.2 Ambiente Geopedológico II: Solos desenvol vidos sobre sedimentos aluvionares ..... 86

4 A APLICAÇAO PARA A GEOLOGIA DE ENGENHARIA - 0 ZONEAMENTO GEOTECNICO .............. 96

5 CONSIDERAÇOES FINAIS ................ 117

REFERENCIAS BIBLIOGRAFICAS ............. 124 
1. Localização e acesso do Distrito Agroindustrial do Jaiba ............................. 31

2. Mapa geológico e geomorfológico ........... 37

3. Perfil de sondagem em sedimentos aluvionares .. 39

4. Perfil de sondagem em sedimentos coluvionares. 40

5. Mapa pedolögico $\ldots \ldots \ldots \ldots \ldots \ldots \ldots \ldots \ldots .45$

6. Mapa geopedolögico aplicado à Geologia de Enge nharia (zoneamento geotécnico) ........... 98

7. Variações do indice de plasticidade em função do teor do solo em elementos finos e da nature

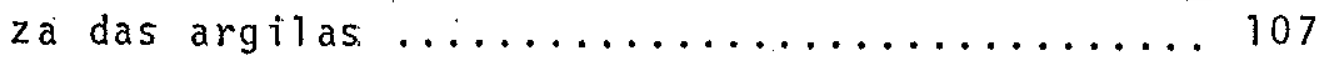

8. Seção geolögico-geotēcnica representativa dos sedimentos aluvionares (terraço superior) .... 111

9. Seção geológico-geotécnica representativa dos sedimentos aluvionares e coluvionares ....... 112 
1. Associação de espécies vegetais naturais com

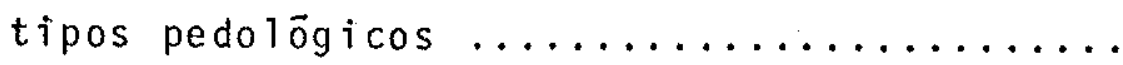

2. Caracteristicas físicas principais do Lato sol Vermelho Escuro distrōfico (LEd) obtidas segundo EMBRAPA /EPAMIG/RURALMINAS, 1976 ...

3. Características quîmicas principais do Lato sol Vermelho Escuro distrōfico (LEd) obtidas segundo EMBRAPA/EPAMIG/RURALMINAS, $1976 \ldots$

4. Características físicas principais do Lato sol Verme Tho Amarelo distrófico (LVd) obti das segundo EMBRAPA/EPAMIG/RURALMINAS, 1976.

5. Características quîmicas principais do Lato sol Vermelho Amarelo distrifico (LVd) obti das segundo EMBRAPA/EPAMIG/RURALMINAS, 1976.

6. Características físicas principais do Cambi sol eutrófico base substrato calcārio ( $\mathrm{Ce}_{1}$ ) obtidas segundo EMBRAPA/EPAMIG/RURALMINAS

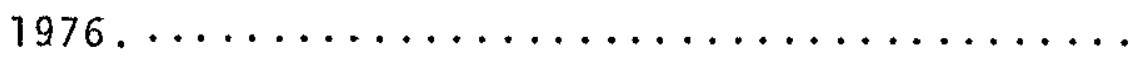

7. Caracteristicas químicas principais do Cambi sol eutrófico fase substrato calcärio ( $\left.\mathrm{Ce}_{1}\right)$ obtidas segundo EMBRAPA/EPAMIG/RURALMINAS,

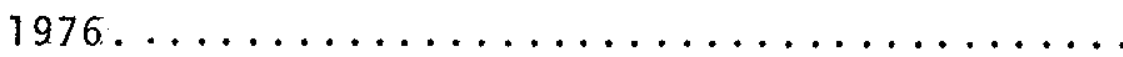

8. Caracteristicas físicas principais do Cambi sol eutrófico fase sedimentos argilosos $\left(\mathrm{Ce}_{2}\right)$ obtidas segundo EMBRAPA/EPAMIG/RURALMINAS ,

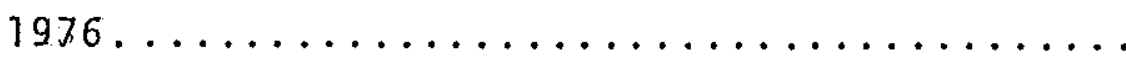

9. Caracterîsticas químicas principais do Cambi sol eutrófico fase sedimentos argilosos $\left(\mathrm{Ce}_{2}\right)$ obtidas segundo EMBRAPA/EPAMIG/RURALMINAS,

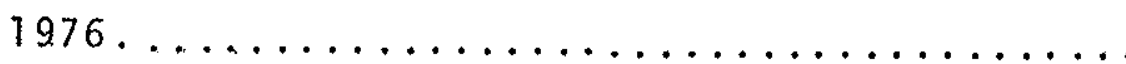

10. Caracterĩsticas físicas principais do Cambi sol eutröfico A chernozêmico $\left(\mathrm{Ce}_{3}\right)$ obtidas segundo EMBRAPA/EPAMIG/RURALMINAS, 1976.... 
11. Caracteristicas quimicas principais do Cambi sol eutrófico A chernozêmico $\left(\mathrm{Ce}_{3}\right)$ obtidas

- segundo EMBRAPA/EPAMIG/RURALIIINAS, 1976.....

12. Caracterīsticas físicas principais das Areias Quartzosas diströficas (AQd) obtidas segundo EMBRAPA/EPAMIG/RURALMINAS, $1976 \ldots \ldots \ldots \ldots$

13. Caracteristicas quimicas principais das Areias Quartzosas distróficas (AQd) obtidas segundo EMBRAPA/EPAMIG/RURALMINAS, $1976 \ldots \ldots \ldots \ldots$

14. Associações Geopedolögicas .............. 75

15. Composição dos Argilominerais nos diferentes tipos pedolögicos, por difratometria de Raios$X$ fração inferior a $2 \mu \ldots \ldots \ldots \ldots \ldots \ldots$.

16. Composição dos Argilominerais nos diferentes tipos pedologicos, por difratometria de Raios-

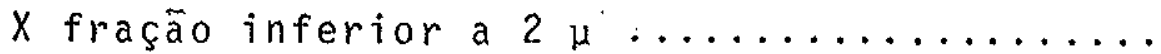

17. Composição dos Argilominerais nos diferentes tipos pedolögicos, por difratometria de Raios$X$ fração inferior a $2 \mu \ldots \ldots \ldots \ldots \ldots \ldots$.

18. Caracteristicas texturais, mineralógicas e me cânicas das unidades geotécnicas homogêneas..

19. Caracteristicas texturais, mineralógicas e mecânicas das unidades geotēcnicas homogêneas

20. Caracteristicas geotēcnicas e previsão do com portamento das unidades geotēcnicas homoge $\overline{\bar{e}}$ neas ............................. 104 


\section{FOTOS}

P.

1. Paisagem de ocorrência do Latosol Vermelho escuro diströfico (LEd). Notar a grande inci dência de "Murundus" dispersamente distribu dos na superfície do terreno. Estrada Mocambi nho Janaüba, Km $65 . \ldots \ldots \ldots \ldots \ldots \ldots \ldots \ldots \ldots \ldots \ldots \ldots$

2. Corte mostrando perfil de Latosol Vermelho Amarelo distrófico (LVd). Estrada Mocambinho-

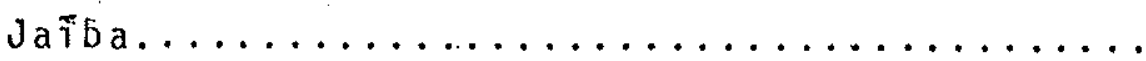

3. Vista geral do relevo em āreas de ocorrēncia do Latosol Vermelho Amarelo distrōfico (LVd) e do Cambisol eutrófico, ambos associados ao terraço superior. O Cambisol eutrófico ( $\left.\mathrm{Ce}_{2}\right)$ distribui-se na parte deprimida do terreno. Es trada Mocambinho-jaíba...............

4. Vista geral do relevo em āreas de ocorrēncia do Latosol Vermelho Escuro distrófico (LEd), e Cambisol eutrófico, associados a sedimentos coluvionares. O Cambisol eutröfico $\left(\mathrm{Ce}_{\gamma}\right)$ distribui-se na parte deprimida do terreno. Es

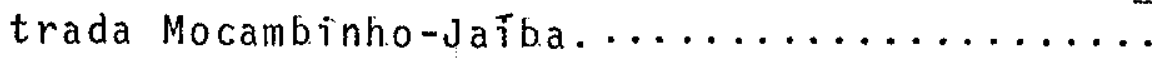

5. Trincheira mostrando perfil de Cambisol eutrō fico substrato calcärio $\left(\mathrm{Ce}_{\eta}\right)$. Notar a parte inferior do perfil, no contato com o substra to, com concentração de concreções de limon ta. Estrada Mocambinho/Jajba ...........

6. Trincheira mostrando perfil de Cambisol eutrō fico $\left(\mathrm{Ce}_{1}\right)$ em transição para Latosol Verme Tho Escuro distrófico (LEd). Estrada Mocambinho-

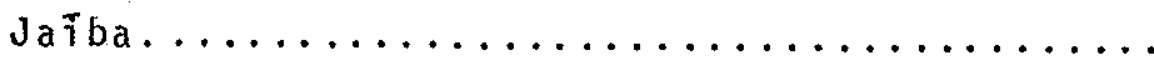

7. Trincheira mostrando perfil de Cambisol eutró fico A chernozêmico $\left(\mathrm{Ce}_{3}\right)$. Estrada Mocambinho-

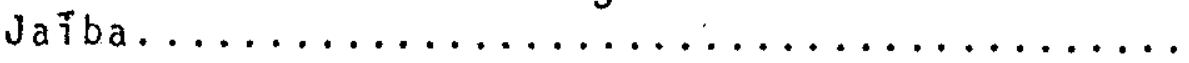


8. Trincheira mostrando perfil de Cambisol eutrö fico chernozêmico $\left(\mathrm{Ce}_{3}\right)$ em transição para La tosel Vermelho Escuro diströfico (LEd).......

9. Detalhe de uma amostra proveniente do nivel in termediärio em perfil de Latosol Amarelo dis

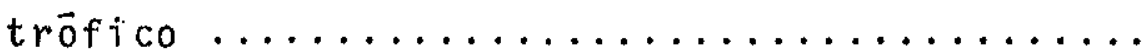

10. Corte mostrando o perfil de Areias Quartzosas distróficas (AQd) distribuĩdas no terraço su perior. Jazida de solo utilizadd em aterros do canal principal do Projeto Jajba........

11. Perfil de Areias Quartzosas distróficas (AOQd) do terraço superior. Notar a mudança de colo ração da parte superior do perfil para a par te inferior. devido ao aumento no teor de ar gila. Jazida de solo utilizado em aterros do canal principal do Projeto Jaiba.......... 


\section{INTKODUÇAO}

A áplicação dos conhecimentos geológicos em Enge nharia Civil realiza-se atravēs da Geologia Aplicada à Engenharia ou simplesmente Geologia de Engenharia, es tando intimamente ligada a duas outras āreas de atuação na Engenharia Civil: Mecānica dos Solos e Mecānica das rochas.

A Mecânica dos Solos (Leinz e Leonardos, 1970) es tuda a constituição e propriedades físicas do solo ( la to sensule dos sedimentos incoerentes com o fim da sua aplicação nâ Engenharia Civil, enquanto a Mecānica dás Rochas "busca a investigação e caracterização das pro priedades físicas e comportamento mecânico das rochas".

0 papel do geólogo na Geologia de Engenharia, isto é, a contribuição da Geologia durante as fases de im plantação de uma obra civil, ē uma questão que vem, hä longo tempo, sendo entre nös debatida, tendo em vista principalmente a sua importância na consolidação da Geo logia de Engenharia. Segundo 01iveira (1981), esta con solidação teve como marco significativo no Paîs a reali zação do 29 Congresso Internacional de Geologia de Enge nharia em 1974.

A compreensão histórica da evolução da Geologia de Engenharia no Brasil asseguramos o entendimento da sua consolidação e tendências de seu futuro desenvolvimento. 
Neste particular, 01 iveira (1981) apresenta uma anālise histōrica dessa evolução, onde identifica algumas fases do seu desenvolvimento no Brasit.

A Geologia de Engenharia no Brasil iniciou-se pra ticamente a partir do ano de 1937 com a instalação da Seção de Geologia e Petrologia no Instituto de Pesqui sas Tecnolōgicas de São Paulo. Caracterizou-se esta fa se inicial pela dedicação de alguns tēcnicos, destacan do-se a figura de Ernesto Pichler, que durante 20 anos introduziu e divulgou importantes trabalhos pioneiros, e que serviram como modelo para o desenvolvimento da Geologia de Engenharia no Brasil. Esta fase è caracte rizada (01jveira, 1981) como de "importação e adaptação do conhecimento da Geologia de Engenharia".

A fase seguinte a se destacar no desenvolvimento da Geologia de Engenharia no Brasil inicia-se nos prị meiros anos da década de 60 , com a construção de gran des obras hidroelétricas e de estradas, especialmente na região centro-sul do País. Essas obras, financiadas em sua grande maioria por organismos internacionais, ti veram por exigēncias contratuais a necessäria participa ção do geōlogo, desde as etapas iniciais do projeto, até a sua implantação. Essas exigências foram concretizadas tendo em vista importantes acidentes de barragens ante riormente ocorridos, principalmente na Europa, onde fe nômenos geológicos se destacaram como causas principais. 
E praticamente nesta fase que a Geologia de Engenharia no Brasil assumiu o papel de destaque nas obras de En genharia Civil, agora não majs caracterizadas por esfor cos individuais, mas por trabalhos em equipe, consoli dando a sua atuação. Por outro lado, quer pela necess dade sentida pelo geōlogo de engenharia de uma maior afirmação junto ao engenheiro nos "canteiros da obra, e mesmo nas empresas, quer pela necessidade de entender ou fazer-se entender pelos engenheiros, observou-se du rante essa fase de desenvolvimento da Geologia de Enge nharia uma intensa preocupação do geölogo em aprofun dar os seus conhecimentos em Engenharia Civil. Isso ge rou uma tendência clara à especialização do geōlogo de engenharia, muito bem caracterizada por Camargo (1976). "Os geōlogos passaram a dedicar maior tempo de estudo a disciplinas da Engenharia Civil, tais como mecānica dos solos, resistência dos materiais e materiais de constru ção, em detrimento da Geologia propriamente dita". Den tro desta mesma linha de raciocínio, 01iveira (1981) as sinala que o geōlogo de engenharia em "seu trabalho, se guindo a construção das obras, familiarizando-se com as exigēncias dos projetos de Engenharia Civil e acompa nhando o desenvolvimento da Mecānica das Rochas, desen volveu métodos importantes na forma de enfocar os pro blemas geotēcnicos orientados preferencialmente para a quantificação das feições e fenōmenos geolōgicos". Esta 
fase da desenvolvimento da Geologia de Engenharia pode ser caracterizada, portanto, como de diversificação e especialização da atuação do geōlogo de engenharia.

Finalmente, a fase atual do desenvolvimento da Geo logia de Engenharia no Brasil afigura-se como a retoma da do pensamento geolögico aplicado à solução dos fenô menos geolögico-geotëcnicos ocorrentes em obras de Enge nharia civil. Essa tendência é caracterizada por Camar go (1976), como o início de "um movimento espontāneo, por parte dos geölogos que participaram dos primeiros passos da Geologia Aplicada, de retorno ã ênfase em Geo logia". Há de se citar a oportunidade do trabalho de Santos, A. (1976) apresentado no 10 Congresso da Associação. Brasileira de Geologia de Engenharia - "Por menos en saios e instrumentações e por uma maior observação da natureza", traduzindo com bastante acerto essa nova ten dência da Geologia de Engenharia no Brasil.

Este trabalho conclui pela proposição de uma meto dologia a ser aplicada em Geologia de Engenharia, que apesar de restrita a estudos de taludes em estradas, dá as orientações básicas. a serem adotadas pelo geölogo tendo em vista a aplicação do raciocĩnio geológico em Engenharia Civil. Assim, salienta esse autor que, "a idēia băsica é de chegar à compreensão de um determina do fenômeno, não pela anālise particular de cada parāme tro envolvido, mas sim pelo entendimento deste fenōmeno 
como um todo, ou seja, como resultado da interação de um quadro geológico, definido pelo conjunto de todos os parâmetros intrĩnsecos ao material, com o tipo de soli citação a que esteja submetido", salienta tambëm que "o fim desejado seria a definição de modelos fenomenológi cos que traduzissem o comportamento das diversas situa ções geolögicas diante de diferentes solicitações impos tas pela obra". Essas orientações, introduzidas por san tos (1976) em projetos viārios, foram aplicados com bas tante sucesso em vārios estudos desenvolvidos por tēcni cos do Agrupamento de Geologia Aplicada da Divisão de Minas e Geologia Aplicada do Instituto de Pesquisas Té notōgicas do Estado de São Paulo, sendo divulgados prin cipalmente através de trabalhos publicados no 10 e 20 Congresso Brasileiro de Geologia de Engenharia, realiza dos respectivamente em 1976 e 1978. Inicialmente a apli cação desse enfoque metodológico foi restrita a estudos de consolidação de taludes rodoviārios e ferroviärios, sendo posteriormente adaptado a outros projetos de En genharia Civil.

Sendo esta a tendēncia atual, ou seja, o entendi mento dos fenômenos que regem a evolução geológica do meio físico, não sō a Geologia de Engenharia vem reassu mindo suas bases cientificas na Geologia como buscando a colaboração de outras ciências que se dedicam a com preender o mesmo meio, embora com enfoques diversos. 
Neste carāter multidisciplinar do estudo do meio físico destaca-se a Pedologia como uma das ciēncias que podem enriquecer os trabalhos de Geologia de Engenharia. E neste quadro de intercāmbio científico que deve ser con siderada a elaboração da presente dissertação.

Destaca-se ainda como importāncia na aplicação da Pedologia em estudos de Geologia de Engenharia, o fato de existirem nọ Brasil predomināncia de āreas cobertas por solos variados e de espessuras considerāveis.

Entretanto, a aplicação dos conhecimentos: pedolögi cos no Brasil tem sido utilizada mais restritamente com vistas ao aproveitamento dos solos na agricultura, res salvando-se a iniciativa pioneira do Engo. Job Shuji Nogami e trabalhos de pesquisa desenvolvidos por alguns Institutos e Universidades, onde se destacam: Instituto de Geociências da Universidade de São Paúlo, Instituto de Geociências da Universidade Federal do Rio de Janei ro, Universidade Federal da Paraíba, Instituto de Pes quisas do Estado de São Paulo, Associação Brasileira dos Produtos de Cal. Nogami (1971) comenta que as parti cularidades ligadas aos nossos solos, decorrentes princi palmente das condições climäticas intertropicais predo minantes em nosso Pais, leva-nos a necessidade de adap tarmos a metodologia dos estudos de solos às nossas con dições. Acrescenta tambēm que "o acümulo de dados ade quadamente analisados e correlacionados, permitirā o 
controle dos futuros trabalhos rotineiros e possibilita rā a previsão direta do comportamento dos principais ti pos genëticos de solos". Dessa maneira, conclui Nogami (1971) que "em futuro não muito remoto, teremos acumula do dados suficientes para o desenvolvimento de uma tēc nica para o estudo de solo, mais condizente com as pecu liaridades geolögicas, pedolögicas e climáticas prevale centes em nosso País".

. E dentro destas preocupações que se insere esta dissertação de mestrado, procurando contribuir, em ter mos metodolögicos, com uma proposta a ser adotada princi palmente numa fase de estudos preliminares. Pretende-se, neste trabalho, indicar os estudos mïnimos necessärios do meio físico, sua execução e interpretação, de mane ra a apontar, numa dada região, a distribuição de ocor rēncias geneticamente homogēneas de solos, orientado ao estudo de Geologia de Engenharia. A aplicação da propos ta metodológica a ser apresentada serā ilustrada com tra balhos desenvolvidos no Distrito Agroindustrial do Ja ba, municipio de Manga, MG, visando estudos geológico -geotêcnicos para implantação de projeto de irrigação. 


\section{CONSIDERACOES PRELIMINARES}

Neste item serão abordados resumidamente alguns aspectos conceituais considerados importantes para a compreensão dos resultados apresentados nesta disserta ção de mestrado, e a seguir os mëtodos de trabalhos uti lizados para o seu desenvolvimento.

\subsection{Solo: Conceitos Bäsicos Pedogenēticos}

0 solo, dependendo dos objetivos e enfoque cienti fico, tem interpretações variadas. Entre as interpreta ções mais importantes destacam-se as relacionadas à En genharia Civil, Agronomia, Geologia e Pedologia.

Para a Engenharia Civil $\bar{e}$ bastante disseminada no meio técnico a interpretação para o solo como sendo "to do material encontrado na superfïcie da crosta terres tre escavāvel por meio de picareta, pä, escavadeira, etc. ou ainda, que perde sua resistência quando em con tato prolongado com a ägua" (Milton Vargas, 1974).

A Agronomia, tendo em vista o interesse no conheci mento do solo para fins agrĩcolas, restringiu a sua in terpretação à camada superficial de terra arävel possui dora de vida microbiana.

A Geologia, parte da interpretação do solo como produto do intemperismo físico e químico das rochas. Em função disso, foi a ciência que pela primeira vez procu 
rou estudar o solo tendo como objetivo não sö a sua apli cabilidade, mas tambēm a sua formação e desenvolvimento.

$\mathrm{Na}$ concepção pedolōgica o solo è entendido como corpos naturais organizados, com distintas naturezas prōprias e que evoluem atravês de estägios de gênese, maturidade e degradação. Essa conceituação foi primeira mente apresentada e desenvolvida na Rüssia por Doku chayev em 1880: Percebeu-se assim que o solo não pode ria apenas ser compreendido como simples camada super ficial, produto do intemperismo das rochas, mas resulta do de uma complexa interação de fatores que incluiam alēm da rocha, o clima, matēria orgānica, topografia, e o tempo transcorrido sob a ação desses fatores.

A partir dos estudos desenvolvidos por Dokuchayev, a Pedologia rapidamente se consolidou como ciēncia, pas sando a envolver especialidades diversas no estudo do solo, onde se destacam: a Quĩmica, a Física, a Biologia e a Geologia. Assim, uma sērie de conceitos pedolögicos sobre o solo foi apresentado por renomados pesquisado res. Uma definição de solo bastante completa e atualiza da $\bar{e}$ apresentada por Birkeland (1974): "material natu ral consistindo-se de camadas ou horizontes de compos tos minerais e/ou orgãnicos com variadas espessuras, diferindo do material original por propriedades morfolo gicas, físicas, químicas e mineralögicas e por caracte risticas biolögicas. Os horizontes do solo geralmente 
são inconsolidados, mas alguns contêm suficientes por ções de sîlica, carbonatos, ou öxidos de ferro para ci mentā-los".

Uma das grandes contribuições deixadas por Dok chayev no campo da Pedologia foi em conceituar o solo, não como um simples suporte detrítico mais ou menos rico em substancias nutritivas, mas como uma entidade na tural complexa'e sujeita a continua modificação.

Concluiu Dokuchayev que o desenvolvimento do solo e realizado com base em cinco diferentes fatores: 1) o clima local, condicionando principalmente a ação da āgua, temperatura, oxigênio e diōxido de carbono; 2) os materiais de origem; 3 ) os organismos, vegetais e ani mais; 4) o relevo e a altitude; 5) o tempo transcorrido sob ação desses fatores.

Esses principios definidos por Dokuchayev contri buïram não só pela identificação de uma nova ciēncia, a Pedologia, como tambēm orientaram inümeros pesquisado res na formulação de teorias evolucionistas do solo. A genëtica e a evolução do solo passam então a representar um papel muito importante na sistemătica classificatō ria dos solos adotada em vārios paises. Neste sentido, Duchaufour (1977) afirma: "todas as classificações mo dernas de solos - pelo menos no que diz respeito às uni dades superiores - têm base genética, pode-se dizer que elas levam em consideração o processo evolutivo e o 
grau de evolução". Ainda, de acordo com Duchaufour, as primeiras classificações pedolṇ̃icas se apoiavam exclu sivamente na "ecologia" dos solos, isto é, nas condi ções do meio que interferem na sua evolução, com ênfase especial. ao clima e a rocha-mãe; com o aprofundamento do conhecimento pedogenético, especialmente quanto aos processos bioquímicos e físico-químicos, a interferēn cia destes processos na evolução dos solos foi sendo considerada nas classificações pedológicas.

De uma maneira bastante simples, Principi distingue na formação do solo duas fases sucessivas: o intemperismo, representado pelos fenömenos físicos e quīmicos, que, agindo sobre a rocha conduzem à formaçãodo substrato pedogenëtico, e alteração pedológica, que cor responde à ação dos processos pedogenëticos, transfor mando o substrato num verdadeiro solo.

Entretanto, essas duas fases não ocorrem isolada mente, uma vez que ao mesmo tempo que as rochas são sub metidas ao intemperismo físico e químico, elementos mais solūveis provenientes dessa alteração dão condições à vida vegetal, fazendo crescer os efeitos sobre o manto de intemperismo e contribuindo para adiferenciação do perfil em horizontes pedolögicos.

Dentro deste mesmo raciocĩnio, Duchaufour (1977) conclui que, como resultado da pedogẽnese, o solo, ini cialmente superficial, se aprofunda progressivamente, 
diferenciando estratos sucessivos pela cor, textura e estrutura, e constituindo no conjunto o perfil do solo. " 0 estudo aprofundado do perfil permite compreender a ação de diversos fatores do meio, de reconstituir a his tōria do solo: as caracteristicas dos horizontes tradu zem a ação de certos processos bioquímicos ou físicoquîmicos; estes processos, por outro lado, se explicam pelos fatores ecolögicos". Duchaufour justifica essa apreciação pela trilogia:

Ecologia $\longrightarrow$ Processos Pedogenéticos $\longrightarrow$ Caracteres do Perfil.

Essa relação dinâmica observada durante a formação do solo traduz a importância em se conhecer, à luz dos fatores do meio, os processos pedogenéticos fundamen tais.

E muito comum encontrarmos termos como podzoliza ção, laterização, carbonatação, salinização, etc., iden tificados por processos pedogenéticos.

"Segundo a nova maneira de encarar os fenōmenos pe dogenēticos, não haveria ocorrência de processos especí ficos na formação de determinado solo. Ao contrārio, eles apresentariam uma sērie de propriedades em comum, resultantes de processos variados que se manifestariam simultaneamente em grande parte, se não em todos os so los" (Moniz, 1972). 
Entre os vārios autores que apresentaram essa nova concepção dos processos pedogenáticos, destaca-se o tra balho de simonson (1959), que considera a existencia de basicamente cinco processos (adições, transformações, transportes seletivos, remanejos mecânicos e perdas), cada qual compreendendo uma série de mecanismos caracte rīsticos. A atuação e predominãncia de um processo so bre o outro depende do meio-ambiente considerado; por tanto, qualquer modificação ambiental provoca imediata mente alterações no curso da pedogẽnese. Simonson con sidera, ainda, que a atuação combinada dos processosque conduzem ao desenvolvimento pedogenëtico verifica-se se gundo dois estāgios diferentes, que se superpõem: a for mação ou acumulação do substrato pedogenético e a dife renciação dos horizontes.

Essa mesma concepção de processo pedogenētico é, de maneira mais objetiva, apresentada por Duchaufour (1977), que considera a reunião dos diferentes processos em três fundamentais: incorporação da matéría orgãnica, altera ção física e quĩmica das rochas e movimentação da matē ria do solo.

\section{Incorporasão da Matéria Orgânica}

Duchaufour (1977) distingue a existencia de duas fases na transformação da matēria orgānica; a primeira resultante de uma evolução mais ou menos räpida da ma 
tëria orgânica, e a segunda, de uma evolução lenta e pro gressiva.

A primeira fase de transformação da matēria orgāni ca é essencialmente condicionada pela natureza da matē ria primäria (restos vegetais que caem no solo), e pe las condições físico-químicas do meio, relacionadas prin cipalmente ao pH. Por outro lado, a segunda fase estā ligada muito mais diretamente a condições externas, em particular do meio climätico.

Durante a transformação rāpida da matēria orgānica, distingue-se a importāncia de dois produtos diferentes: fração insolüvel, formada por compostos mais resistên tes à decomposição (lignina, celulose e hemicelulose) e fração solüvel constituída por certos glucídios, tani nos, e aminoācidos. A fração insolūvel em parte se de compõe progressivamente, dando origem a novos compos tos solüveis (neoformados), restando ainda uma outra parcela que se mantëm insolüvel, incorporando-se pro gressivamente ao solo.

A fração solūvel (herdados ou neoformados) $\vec{e}$ em parte absorvida por microorganismos, mineralisando-se ou integrando-se aos tecidos microbianos, enquanto que as parcelas restantes, mais resistentes à biodegradação microbiana, resultam na edificação de compostos hü micos. Estes compostos solüveis exercem papel fundamen tal no curso da pedogênese; "em certos casos, eles blo 
queiam toda mineralização do nitrogênio e dificultam a humificição, em outros, ao conträrio, eles se insolubi lizam rapidamente, formam os cimentos hümicos necessä rios às estruturas e não impedem em hipōtese alguma a mineralização concomitante do nitrogênio" (Duchaufour, 1977).

A evolução fĩsico-quĩmica lenta da matēria orgâni ca, também denominada por Duchaufour de "maturação", verifica-se atravēs de um aumento da polimerização das molēculas hümicas, e de um incremento nas ligações com os compostos minerais, principalmente as argilas; 0 hü mus formado adquire um equilitbrio estāvel dependente principalmente das condições do meio; assim, "a cor, a espessura, a estrutura e a essencia das propriedades físico-químicas do horizonte misto $A_{1}$ dos perfis depen dem deste equilíbrio".

\section{Alterasão Física e Quimica das Rochas}

0 processo de alteração das rochas, formando a fra ção mineral do solo, realiza-se atravēs da desintegra ção fïsica e mecânica e atravēs da alteração quîmica. No primeiro caso observa-se um aumento da superficie especĩfica das partículas minerais, sem modificações na sua estrutura cristalina. No segundo caso ocorre uma alteração dos minerais primärios, com formação de minerais secundārios, que se constituem no complexo de alteração. 
Para o estudo pedogenētico, a alteração química dos minerais tem um significado mais destacado, tendo em viša a liberação dos produtos solūveis (base e sîli ca), cātions menos solüveis (ferro e aluminio, princi palmente) e argilo-minerais, fundamentais na evolução do perfil. Entre os värios processos de alteração quîmi ca (hidrōlise, oxidação, redução, hidratação, carbonata ção, quelação e troca de ĩons), a hidrölise ē, sem dūvi da, a mais importante. Essa importância se manifesta principalmente em regiões de clima tropical e subtropi cal, como é o caso do nosso País. Ela atua principarmen te em rochas cristalinas pela reação de ions $\mathrm{H}^{+}$e $\mathrm{OH}^{-}$, dissociados da àgua, com os ions de elementos minerais. Sua ação varia consideravelmente segundo as condições do meio, principalmente do clima.

Conhecem-se dois tipos fundamentais de hidrōise: a hidrōlise total, caracterizada pela liberação comple ta dos constituintes dos minerais (silica, aluminio, ba ses, etc.) fato comum em regiões de clima tropical ümi do; e a hidrölise parcial, que não destrōi totalmente a rede cristalina inicial dos minerais, sendo caracterís tica de regiões de clima temperado e tropical semi-äri do. No primeiro caso as argilas resultantes são princi palmente do tipo neoformadas, enquanto que, no segundo caso, resultam principalmente de uma transformação pro gressiva dos minerais primärios. 
0 fenômeno de hidrōlise total, com liberação da sí lica e bases na forma de hidróxidos, permite a concen tração do hidröxido de alumīnio, normalmente insolūvel, formando minerais do tipo gibbsita $\left(\mathrm{A} 1(\mathrm{OH})_{3}\right)$. Esse pro cesso de alteração é denominado de alitização por Har rassowitz (1926) (citado por Melfi e Pedro, 1977).

Por outro lado, na hidrölise parcial a dessilicifi cação do meio é incompleta, permitindo que parte da si lica liberada reaja com o aluminio, formando argilo-mi nerais (hidrossilicatos aluminosos); esse processo è de nominado sialitização. Neste caso, "a eliminação dos cătions bäsicos pode ser mais ou menos elevada". (Melfi e Pedro, 1977); duas condições, dependendo dos minerais em alteração e das condições do meio (drenagem princi palmente), podem ocorrer:

a) eliminação bastante pronunciada dos cātions básicos, permitindo a formação de argito-minerais do tipo $1: 1$ (caulinita);

b) eliminação parcial dos cátions bāsicos, permitindo a formação de argilo-minerais do tipo 2:1 (esmectita).

O primeiro caso foi denominado por Pedro (1966) de monossialitização e o segundo de bissialitização.

Melfi e Pedro (1978) apresentam uma sintese dos di ferentes ambientes geoquímicos de solos encontrados no 
Brasil; este trabalho, de fundamental importāncia para estudos de natureza pedogenética dos solos brasileiros: caracteriza as diferentes formas de hidrōise e sua re partição geogräfica.

\section{Movimentos da Matéria no solo}

A importância deste processo pedogenētico ē tradu zida não sō pela diferenciação e evolução do perfil em profundidade, como tambēm pela diferenciação lateral dos tipos pedológicos. Sua efetivação depende fundamen talmente da ägua gravitacional e ascensional, mais ou menos enriquecida de certos elementos coloidais, seja em solução, seja sob a forma de suspensão.

Duchaufour (1977) denomina esse processo de migra ção e considera a existência de dois tipos bäsicos:

a) migrações descendentes (vertical e obliqua);

b) migrações ascendentes.

Na migração descendente uma parte dos elementos são transportados para fora do perfil e outra parte é redistribuĩda internamente no perfil, permitindo a dife renciação do perfil nos horizontes eluviais (horizonte A) e horizonte iluviais (horizonte $B$ ).

A migração descendente realiza-se por certos meca nismos que dependem fundamentalmente do tipo de elemen 
to mobilizado, distinguindo-se, assim, trēs formas de migração:

a) Lixiviagẽo: migração de sais solūieis, representa dos principalmente pela sĭlica e cátions alcalinos e alcalinos terrosos $\left(\mathrm{Na}^{+}, \mathrm{K}^{+}, \mathrm{Ca}^{++}, \mathrm{Mg}^{++}\right)$. os demais elementos são dificilmente eliminados sob a forma de sais; entre as exceçöes incluem-se o $\mathrm{Mn}^{++}$e o $\mathrm{Fe}^{++} \mathrm{I} \underline{i}$ xiviados em meio redutor, e o $\mathrm{Al}^{+++}$em meio muito àcido.

A lixiviação progressiva do solo, eliminando os cá tions alcalinos e alcalinos terrosos, promove a sua aci dificação. Observa-se durante esse processo que o ions monovalentes $\left(\mathrm{Na}^{+}\right.$e $\mathrm{K}^{+}$) são mais facilmente eliminados que os ions bivalentes $\left(\mathrm{Mg}^{++} \mathrm{e} \mathrm{Ca}^{++}\right)$. Por outro lado, o sōdio é o mais mōvel de todos os cātions básicos; so mente em condições de mä drenagem interna e em condi cõos de clima ārido, o sōdio pode acumular-se nos hori zontes superiores do perfil. 0 potássio è tambēm facil mente lixiviado, mas na presença de argilas micäceas, parte dele pode ser adsorvido, permanecendo assim em condições de ser permutado por outros íons. Entre os cä tions bäsicos bivalentes o magnēsio è mais mōvel que o cälcio.

o clima exerce papel fundamental na remoção ou pre cipitação dos cátions alcalinos e: alcalinos terrosos; 
assim, enquanto em regiōes äridas as bases se acumulam em superfície ou nos horizontes superiores, em regiōes de clima ümido, ao conträrio, as bases säo lixiviadas em profundidades do perfil ou para fora do perfil. Em ambos os casos o comportamento do lençol freätico tem uma interferēncia substancial na remoção e na precipita ção desses elementos.

A lixiviação do cālcio depende fundamentalmente da presença do $\mathrm{CO}_{2}$ dissolvido na ägua de chuva, provocando a dissolução dos carbonatos e formando bicarbonato de călcio que è removido em solução. A velocidade do pro cesso è portanto função principalmente das precipita ções pluviométricas.

A sĩlica migra em solução na forma de ācido silíci co, e sua intensidade depende do $\mathrm{pH}$ e da solubilidade do aluminio. A precipitação do alumínio provoca uma cer ta adsorção de șilica solüvel por este elemento, promo vendo a neoformação da argila. Portanto, "a quantidade de sillica restante em solução estä, de certa forma, em relação inversa com a quantidade de argila neoformada no meio" (Duchaufour, 1977).

b) QueZuviagão: migração de certos elementos, como o fer ro e o aluminio, sob a forma de complexos organo-me tálicos ou quelatos. 
A migração dos complexos organo-metälicos depende principalmente da relação molecular cātion/añ̄on; traba lhos baseados em experimentos de laboratörio, como o apresentado por Schmitzer (1969), mostra que a solubili dade do complexo a um dado pH aumenta quando se diminui a relação cátion/anion do meio. Por outro lado, o pH e Eh do meio têm. uma interferēncia bastante significativa na migração dos complexos organo-metälicos. Schmitzer e Skinner (1962) atravēs de estudos de pedologia experi mental, mostraram que a solubilidade dos complexos orga no-metālicos varia com diferentes valores de pH: "para - ferro, esta solubilidade $\bar{e}$ mais forte de $\mathrm{pH} 3$ ate $\mathrm{pH}$ 5 ; se o pH permanece constante, a solubilidade decresce quando a relação cātion/anion aumenta" (Duchaufour, 1977).

0 potencial de ōxido-redução interfere de maneira fundamental na mobilidade dos cätions metälicos ferro e manganês. 0 ferro e o manganês manifesta-se na nature $z a$ nas formas reduzidas (bivalentes, $\mathrm{Fe}^{2+}, \mathrm{Mn}^{2+}$ ) e oxi dadas (polivalentes, $\mathrm{F}^{3+}, \mathrm{Mn}^{3+}, \mathrm{Mn}^{4+}$ ). Estes elementos, quando se apresentam na forma reduzida, adquirem relat va mobilidade, enquanto que na forma oxidada são pouco möveis. 0 Eh e pH condicionam a redução ou oxidação des ses elementos, sendo portanto fundamentais na sua mob lidade. 
c) "Lessivage": migração de partícula em suspensão (argilas principalmente); este processo, permite a acumulação de argila no horizonte subjacente (hor zonte B), formando o horizonte conhecido como B tex tural. (Bt).

A migração da argila è fenômeno complexo, que de pende em parte das condições do meio (pH, presença de cătions livres $\mathrm{Fe}^{3+}$ e $\mathrm{Al}{ }^{3+}$, e presença de compostos or gānicos solūveis) e da natureza das argilas. Em meio $\bar{a} c i d o$, os cătions livres $\mathrm{Fe}^{3+}$ e $\mathrm{Al}^{3+}$ adquirem poder flo culante, reduzindo ao minimo a mobilidade das argilas. - A matēria orgānica interfere na mobilidade das argilas de maneira indireta, pela complexação dos cātions flocu lantes $\mathrm{Fe}^{3+}$ e $\mathrm{Al}^{3+}$; esta complexação permite a remoção desses cätions neutralizando a sua ação na imobilização das argilas (Gombeer e D'Hoore, 1971, citado por Duchau four, 1977). De maneira direta a matēria orgânica solü vel neutraliza a ação floculante doș cātions livres, criando em torno das partículas isoladas da argila um invölucro hidrōfilo, que aumenta as cargas negativas e forma uma barreira protetora em relação aos cätions flo culantes com carga positiva (Souchier, 1971; Dixit et a1. 1975, citado por Duchaufour, 1977). As argilas de dimensões menores (montmorillonitas) são as que apresen tam major mobilidade (Blume, 1964); são praticamente as 
ūnicas que migram em meio pouco ācido; as argilas micāa ceas (ilitas e.vermiculitas) apresentam certa mobiliria de, mas são contidas pela presença de ions férricos e aluminosos que diminuem as suas cargas negativas; final mente, argilas de grandes dimensões e pouco ativas (caoli nitas) são as que apresentam menor mobilidade, sendo fa cilmente imobilizadas por ions fërricos.

As migraçộes ascendentes são bem mais raras que as descendentes, ocorrendo sob certas condições particula res do meio ambiente. Estas condições resumem-se prati camente no fenômeno da capilaridade, na ação indire ta da vegetação, e na ascensão do lençol freático; no primeiro caso, sais solüveis, pela elevação capilar da ãgua, são transportados das partes inferiores para a su perfície do perfil, onde se precipitam; no segundo caso, espēcies vegetais de raizes profundas, absorvendo ele mentos nutritivos das partes inferiores do perfil, mobi lizam esses elementos para a superficie do terreno, que se incorporam ao solo pela humificação; o terceiro caso é função do regime hídrico local e da permeabilidade do terreno, sendo transportados elementos solúveis e parti culas em suspensão.

\subsection{Mëtodos de Trabalho e Materiais Empregados}

os elementos de estudo abordados nesta dissertação de mestrado estão fundamentados em trabalhos realizados 
pelo IPT no distrito agroindusirial de Jaỉba no Estado de Minas Gerais.

Com base nessa experiência de trabalho foi desen volvida uma metodologia aplicada a Projetos de Engenha ria Civil, que operacionalmente permite, de modo relati vamente simples, interpretar o meio físico e obter da dos geotêcnicos fundamentais ao planejamento e implanta ção de têcnicas e obras visando ao aproveitamento mūiti plo de recursos de solos.

\subsubsection{Roteiro metodológico geral}

Esquematicamente a metodologia utilizada pode ser compreendida da seguinte maneira:

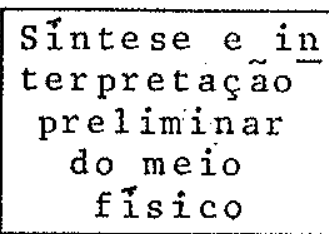


Conforme o quadro esquemätico apresentado, o rote $\underline{i}$ ro metodológico adotado constou basicamente de trēs eta pas de trabalho.

Inicialmente realizou-se uma coleta e anälise de dados existentes sobre o meio físico visando uma inter pretação preliminar. Nessa etapa, procurou-se trabalhar com mapas numa mesma escala, para facilitar as correlações. entre os elementos que constituem a pai sagem. Foi de fundamental importāncia nesta etapa a in terpretação de fotografias aēreas, que fórneceu os da dos bäsicos de geologia, geomorfologia, solos e vegeta ção.

Em seguida, procedeu-se um levantamento de campo, especialmente voltado para a definição das correlações entre geologia, geomorfologia e pedologia. Procurou - se nesse levantamento, observar todas as unidades 1ito lögicas e sistemas de relevo e definir os diferentes ti pos de solos correlacionados ao substrato geológico e à situação geomorfolögica, estabelecendo-se um modelo hipotētico de evolução da paisagem com base no raciocí nio pedogenëtico. Assim, necessariamente os fatores e processos de formação dos solos foram avaliados e defí nidos, constituindo na interpretação geopedolōgica.

Complementando essas observaçaes de campo foram rea lizadas algumas trincheiras e sondagens a trado, nos vă rios tipos pedolögicos e nas diferentes situações topo 
gräficas. Essas trincheiras e sondagens a trado, sempre que po:siveis, escavadas ate o substrato pedológico, permitiram a descrição pormenorizada dos diferentes per fis de solos e coleta de amostras visando ensaios de la boratörio. Esses ensaios de laboratörio tiveram como ob jetivos bāsicos a caracterização fĩsica e química dos diferentes horizontes pedológicos e a caracterização geo tëcnica fundamental, representada por ensaios de granu lometria e indices de consistência.

Finalmente, com base na elaboração e anālise dos dados coletados nas etapas anteriores, procurou-se apre sentar uma interpretação evolutiva dos diferentes solos. Essa interpretação representa suscintamente os diversos ambientes de desenvolvimento pedolögico existentes na região do Jaỉba, definidos com base principalmente na correlação entre o substrato geolögico, relevo, vegetą ção, clima e tipos pedológicos. Cada ambiente de desen volvimento pedolögico reūne portanto solos pedogenetica mente semelhantes, que interpretados para as finalida des da Geologia de Engenharia, resultam em zoneamento geotēcnico.

\subsubsection{Documentação bäsica}

Para a realização dos trabalhos visando a sĩntese e interpretação preliminar do meio fĩsico foram utiliza dos os seguintes elementos: 
- Cartas topogräficas, escala 1:50 000, :0om equi distância das curvas de nivel de 10 em 10 metros, execu tadas pelo Serviço Aerofotogamétrico Cruzeiro do sur, ano 1964/1966;

- Cartas topogräficas, escala 1:100 000, com equi distäncia das curvas de nível de 40 em 40 metros, execu tadas pela Diretoria do Serviço Geogräfico. Ministērio do Exërcito, ano de 1971;

- Fotografias aēreas, escala 1:20 000, vöo realiza do pela base aërea de Recife no ano de 1968;

- Levantamento pedolögico da região obtido atravēs" da publicação - "Levantamento de Reconhecimento com de talhes dos solos do Distrito Agro-Industrial de JaĩbaMinas Gerais", elaborado pela EMBRAPA-EPAMIG-RURALMINAS, com mapa pedolögico na escala 1:125 000, de 1976;

- Relatório IPT nọ 10293 - "Reconhecimento Geoló gico de Superfície da ărea de interesse à implantação do Projeto de Irrigação do Distrito Agro-Industrial de Jaỉba, Municīpio de Manga (MG)", emitido em 1977; 
- Relatōrio IPT nọ 12704 - "Estudos geolögico-geo técnicos da ärea de dominio do canal principal 2-30 000 ha, do Projeto Jaíba (MG)", emitido em 1979.

\subsubsection{Tëcnicas adotadas no trabalho de campo}

Partindo-se da sintese e interpretação preliminar do meio físico, elaborado conforme descrito no item 2.2.1, as atividades de campo tiveram como principal objetivo caracterizar, através de observações puntuais os aspectos de geologia, relevo, vegetação e solos.

A coleta de amostras para ensaios em laboratōio e descrições dos perfis foram realizadas atravēs de trin cheiras e trados, escavados preferencialmente atē o subs trato pedológico. Foram descritos e amostrados 33 per fis de solos representativos da região, totalizando 174 amostras.

Os perfis foram descritos conforme especificações do "Manual de Métodos de Trabalho de Campo", da Socieda de Brasileira de Ciências do Solo (Lemos e Santos, 1973).

\subsubsection{Técnicas de laboratörio}

As amostras coletadas foram analisadas nos labora tōrios do IPT em São Paulo, visando a realização dos se guintes ensaios:

a) caracterização geotécnica: umidade natural, limite de consistência, densidade dos grãos, granulometria; 
b) compactação: umidade ótima $\in$ densidade seca māxima;

c) mineralogia da argila, em termos quantitativos e qua litativos.

os dados referentes às anärises físicas (densidade aparente, densidade real, dispersão da argila, equiva lente de umidade e condutividade elétrica), e as anāli ses quïmicas ( $\mathrm{pH}$, cātions trocāveis, $\mathrm{SiO}_{2}, \mathrm{Al}_{2} \mathrm{O}_{3}, \mathrm{Fe}_{2} \mathrm{O}_{3}$, etc), dos diferentes tipos pedológicos, foram obtidos com base em ensaios realizados pela EMBRAPA - EPAMIG RURALMINAS, cujos resultados e tëcnicas utilizadas fo- ram apresentados no "Levantamento de reconhecimento com detalhe dos solos do Distrito Agroindustrial de Jaj́ba Minas Gerais" (1976).

os ensaios geotécnicos de caracterização e compac tação foram realizados de acordo com as especificações da Associação Brasileira de Normas Tëcnicas-ABNT. Os en saios de caracterização foram preparados conforme a nor ma MB-27, e ensaiadas de acordo com as normas MB-30 (de terminação do Limite de Liquidez), MB-31 (determinação do Limite de Plasticidade), MB-32 (anālise granulomëtri ca) e MB-33 (ensaio normal de compactação).

os ensaios de mineralogia de argila foram realiza dos por difratometria de raio-X, após preparação das amostras de solo e isolamento da fração argila $(<2,4)$. Apōs interpretação dos difratogramas procedeu-se a semi 
-quantificação dos minerais presentes, conforme o mëto do do "padrão interno de ilita", proposto por Johns, Grim e Bradley (1954, in G. Brawn, "The X-ray identi fication and Crystal Structures of Clay Minerals", $p$. 501, Mineralogical Society of London, 1972). 
3 A INTERPRETACAO GEOPEDOLOGICA DO DISTRITO AGROINDUSTRIAL DO JAIBA, MUNICIPIO DE MANGA, M.G.

\subsection{Considerações Preliminares}

O Distrito Agroindustrial do Jaíba, com cerca de 230 mil hectares, localiza-se no municĩpio de Manga, M.G., entre os rios São Francisco e Verde (FIGURA 1).

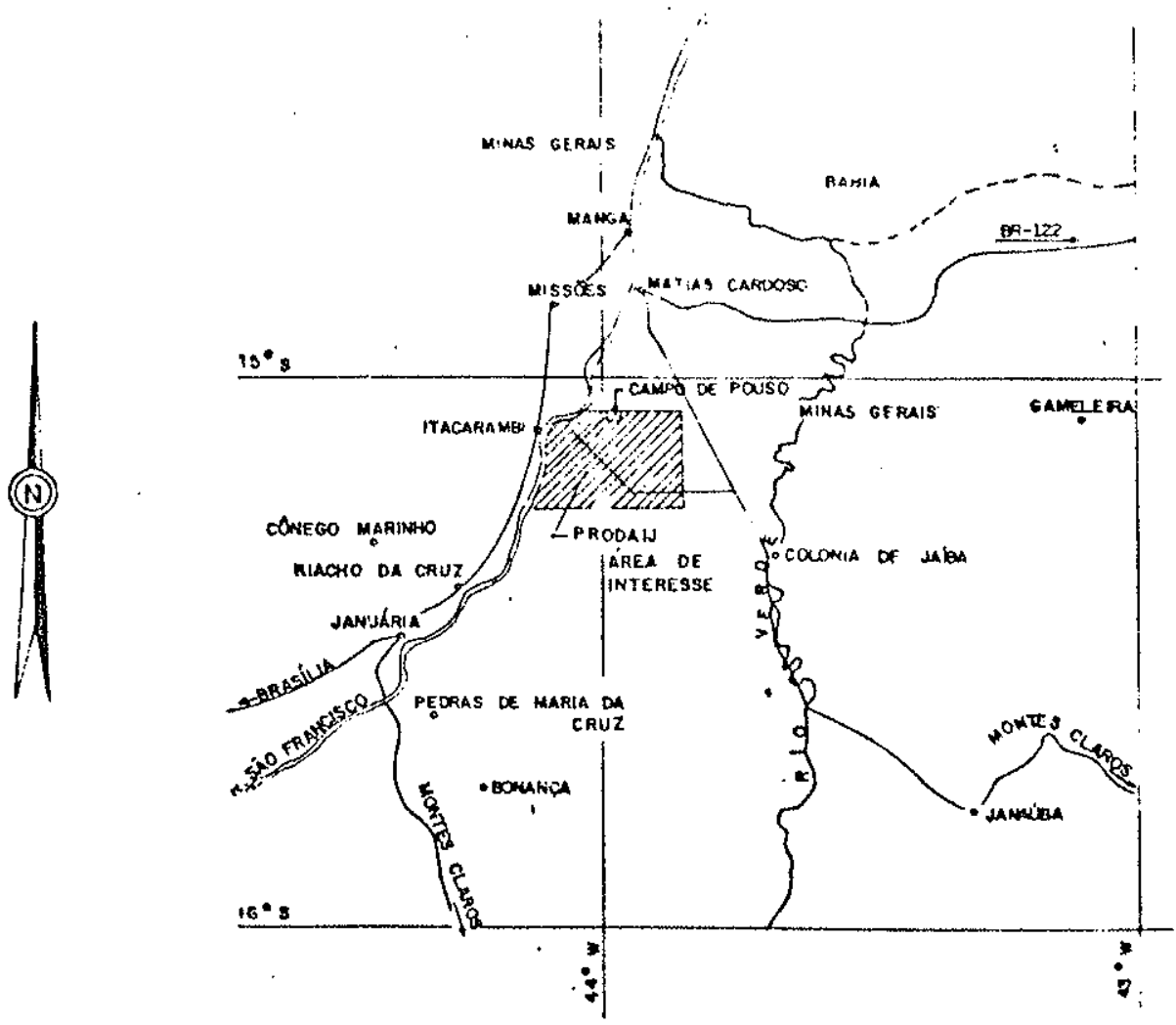

CONVENGŌES

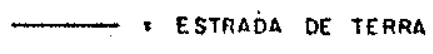

...... DIVISA de ESTADO

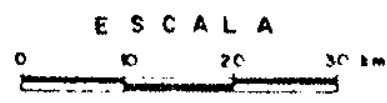

FIGURA 1 - Localização e acesso do Distrito Agroindustrial do Jai ba. 
0 Governo Federal, em conjunto com o Governo do Estado de Minas Gerais, vem desenvolvendo na região um programa de irrigação que pretende numa primeira etapa atingir aproximadamente 100000 hectares. 0 sistema de irrigação a ser adotado e por gravidade, e exigira a adução de $80 \mathrm{~m}^{3} / \mathrm{s}$ de ägua proveniente do rio são Fran cisco.

A ärea a ser irrigada estende-se por três terraços, dispostos em niveis diferentes, como degraus, o que can dicionou a concepção do projeto atravēs de adução de āgua por canais principais, secundārios e terciärios, que se desenvolverão ao longo dos terraços, e por esta ções de bombeamento para vencer os desniveis topogräfi cos entre os terraços.

Tëcnicos do IPT, a convite da Companhia de Desen volvimento do Vale do São Francisco, CODEVASF, atuaram na ärea durante os anos de 1976 a 1979.

Ao iniciar-se a participação tēcnica do IPT no Dis trito Agroindustrial do Jaíba, a CODEVASF com base nos conhecimentos e estudos anteriores da ārea, jā havia de finido a concepcão geral do projeto, onde se incluia lo cação definitiva do canal de adução, situado no primei ro terraço (terraço inferior), o local da estação de bombeamento $n$ o 1 , entre o primeiro e segundo terraços, e o traçado do canal principal no 2, localizado no se gundo terraço (terraço intermediārio). Haviam sido ini 
ciadas tambēm as escavações do canal principal no 1 , cujas dificuldades apresentadas levaram a CODEVASF a so licitar a participação do IPT no projeto. Essas dificul dades evidenciavam a necessidade premente de um maior conhecimento do meio físico da ārea envolvida pelo pro jeto, de maneira a orientar as investigações geotécni cas que se faziam necessärias.

$\mathrm{Na}$ oportunidade os elementos disponĩveis sobre a região de interesse para o projeto resumiam-se em foto grafias aēreas, plantas topogrāficas e levantámento pe dolōgico efetuado pela EMBRAPA/EPAMIG/RURALMINAS, cujo mapa foi apresentado em escala 1:125000.

Procurou-se então, com base na anālise dos dados existentes, fotointerpretação e reconhecimentos de cam po, interpretar o meio físico da região de maneira a es tabelecer as orientações necessārias ao desenvolvimento dos projetos, onde em especial se destacaram:

a) investigações geolōgico-geotēcnicas ao longo do ca nal principal nọ l e no local da estação de bombea mento nọ 1, otimizando o projeto e orientandosua cons trução;

b) investigações geolögico-geotēcnicas para a escolha de alternativa de traçado para o canal principal no 2 e para os locais das estações de bombeamento no 2 e 3; 
c) estudos de seleção de materiais de construção (āreas de "emprëstimo", principalmentel.

A interpretação do meio físico, tendo como referēn cia inicial o mapa de solos em escala 1:125 000, foi substanciada nas correlações entre os elementos de pedo logia, geologia e geomorfologia, fornecendo em pouco tempo e num custo relativamente baixo, os dados bäsicos necessārios para o detalhamento dos projetos.

\subsection{O Meio Geogrä́fico, Geológico e Pedológico}

\section{$3.2 .7 \quad$ Clima}

O clima do Distrito Agroindustrial do Jäba, $\vec{e}$ de finido de acordo com a classificação de Koeppen como do tipo Aw (Galvão e Nimer, 1965). o tipo climātico Aw ē caracterizado como tropical de savana, apresentando a região período chuvoso de novembro atē abril, e os me ses restantes de maio a outubro praticamente secos. A precipitação mëdia anual ē de $876,8 \mathrm{~mm}$, sendo os meses de junho a agosto os mais secos do ano.

o perīodo chuvoso corresponde à ēpoca mais quente do ano, sendo outubro o mēs onde as temperaturas atin gem valores mais elevados, e o mês de julho o mais frio. A mëdia de temperatura da região é de $24^{\circ} \mathrm{C}$ com variação muito pequena durante 0 ano, onde a diferença entre 0 
mês mais quente e mais frio ê menor que $5^{\circ} \mathrm{C}$ (EMBRAPA/ EPAMIG/RURALMINAS, 1976 I.

\subsubsection{Vegetação}

0s tipos vegetais encontrados na região estudada foram agrupados em 3 formaçöes principais: florestas; caatingas e campos de vārzeas (EMBRAPA/EPAMIG/RURALMI NAS, 197.6). Constatou-se uma associação bastante repre sentativa entre as espēcies vegetais dominantes e os ti pos pedolögicos, conforme pode ser observado na TABELA 7.

\begin{tabular}{|c|c|c|}
\hline Formação Vegetal & $\begin{array}{c}\text { Espécies vegetais } \\
\text { predominantes }\end{array}$ & $\begin{array}{l}\text { Tipologia } \\
\text { Pedológica }\end{array}$ \\
\hline Floresta & $\begin{array}{l}\text { Subcaducifölia } \\
\text { Caducifōlia }\end{array}$ & $\begin{array}{l}\text { Solos aluviais eu } \\
\text { troficos textura } \\
\text { argilosa. } \\
\text { Solos aluviais eu } \\
\text { troficos textura } \\
\text { arenosa. } \\
\text { Cambisol Eutrofi } \\
\text { co, Latosol Verme } \\
\text { lho Escuro eutro } \\
\text { fico, Latosol Ver } \\
\text { melho Escuro dis } \\
\text { trofico, solos } \\
\text { Aluviais eutrofi } \\
\text { cos textura média }\end{array}$ \\
\hline
\end{tabular}




\begin{tabular}{|c|c|c|}
\hline Floresta/Caatinga & $\begin{array}{l}\text { Caducifólia e } \\
\text { Caatinga } \\
\text { hipoxerofila }\end{array}$ & $\begin{array}{l}\text { Latosol Vermelho Amarelo } \\
\text { eutrofico, Latosol Verme } \\
\text { Tho Amarelo distrofico. }\end{array}$ \\
\hline Caatinga & $\begin{array}{l}\text { Hipoxerófila } \\
\text { Hiperxeröfila }\end{array}$ & $\begin{array}{l}\text { Areais Quartzosas distro } \\
\text { ficas } \\
\text { Solos Litolicos com ro } \\
\text { chas aflorantes. }\end{array}$ \\
\hline Campos de Vārzea & Herbāceos & $\begin{array}{l}\text { Solos Aluviais eutröfi } \\
\text { cos mal drenados }\end{array}$ \\
\hline
\end{tabular}

TABELA 1: Associação de Espēcies Vegetais Naturais com Tipos Pedolögicos

\subsubsection{Geologia}

A geologia da região estudada pode ser facilmente visualizada atravēs da FIGURA 2. Nota-se assim, sua localização no Craton do São Francisco em ärea de ocor rência de rochas não dobradas do grupo Bambuĩ de ida de Prē-Cambriana Superior, segundo Amaral e Kawashita (1967).

Este grupo compreende diversas formações constituí das por rochas clästicas e carbonäticas, sendo estas ū] timas, constituintes da Formação Sete Lagoas (0 liveira, 1967) as que o representam predominantemente na ärea. Esta formação apresenta na ärea intercalações milimētri cas de siltitos/argilitos. A rocha calcäria, normalmen te de coloração cinza escura, apresenta-se compacta, microcristalina e às vezes oolitica. A coloração escura 


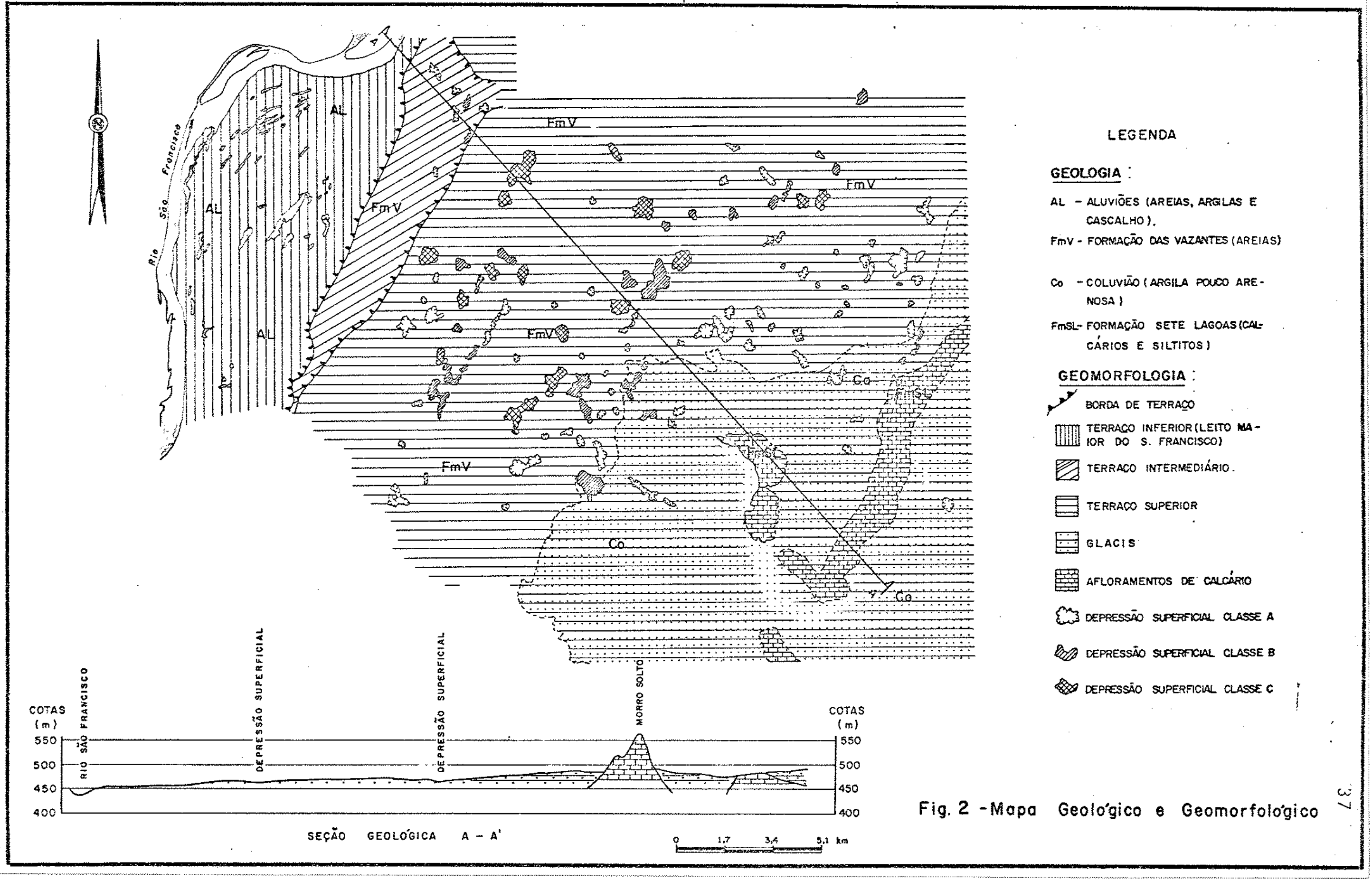


relaciona-se à presença de sulfetos de ferro finamente dispersos e de substāncias orgānicas. A sua composição mineralögica, conforme apresentada por Rodrigues e Silva (1982), demonstra uma "predominância de carbonato de cälcio superior a $90 \%$, seguido por pequenas quantidades de magnësio $(2 \%)$, teores muito baixos de silicatos de aluminio $(1,5 \%$ de argilas) e quartzo, alëm de $2 \%$ de car bono e pequenas quantidades de surfetos, que juntamente com a matēria orgānica dão a cor preta da rocha". obser va-se com frequencia a presença na rocha de veios de calcita recristalizada, de coloração branca ou preta, preenchendo fraturas. Nota-se tambēm a presença nesses veios de calcita de material grafitoso e niveis de piri ta.

Acima do Grupo Bambut, fora da ärea estudada, ocorrem sedimentos continentais que compõem a Forma ção Urucuia, depositadas durante o perĩodo cretäcio. A Formação Urucuia ocorre na margem direita ao sul da ärea de interesse e na margem esquerda do Rio são Francis co.

Durante o Quaternārio depositaram-se aluviões so bre as rochas do embasamento, que constituem a Formação das Vazantes. Ligando porções topograficamente mais ele vadas com esses depōsitos aluvionares observa-se a pre sença de depósitos coluvionares, representadas por um "glacis". As Figuras nọs 3 e 4 apresentam perfis de son 


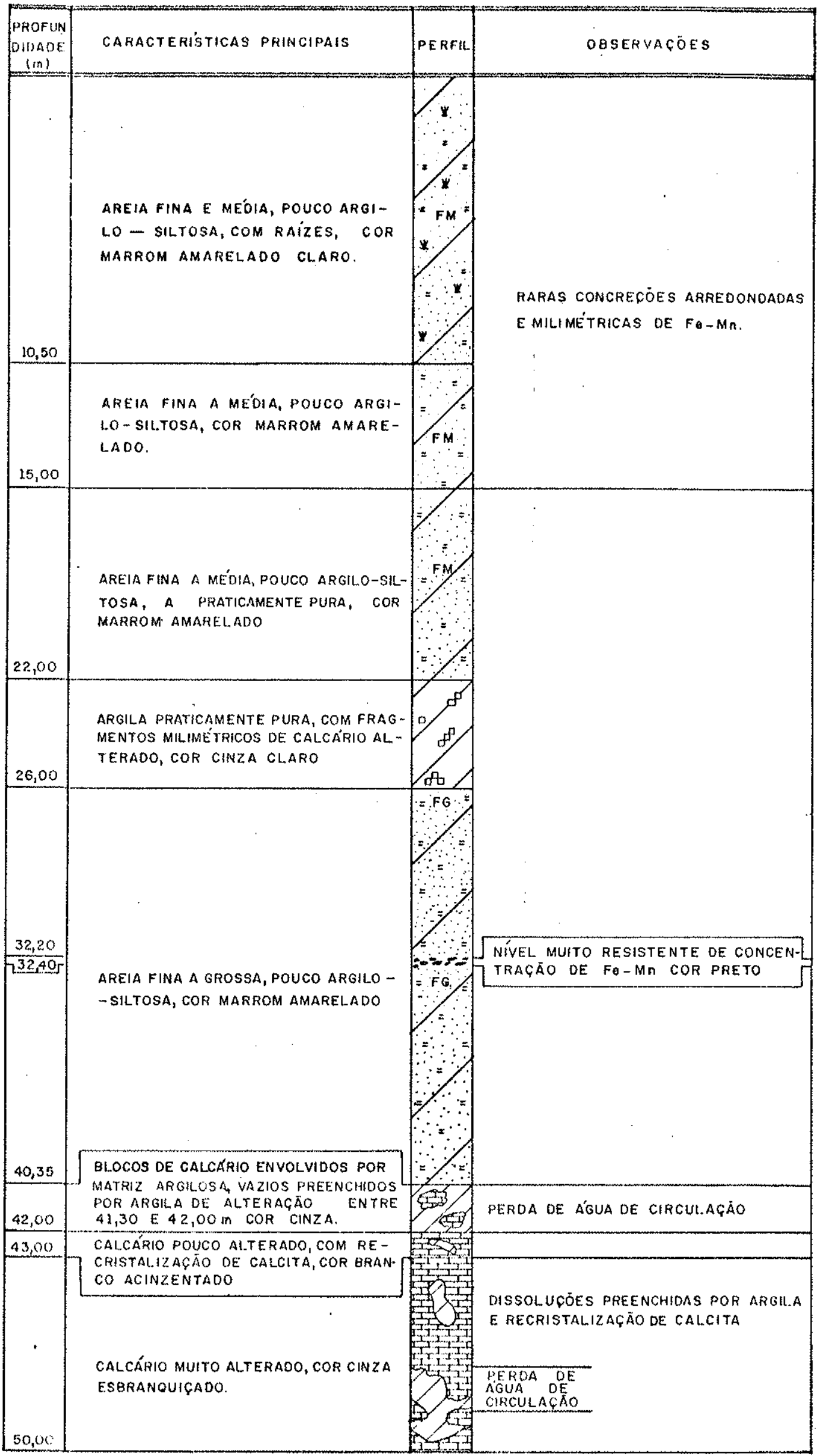

Fig. 3 - Perfil de sondagem em sedimentos aluvionares 


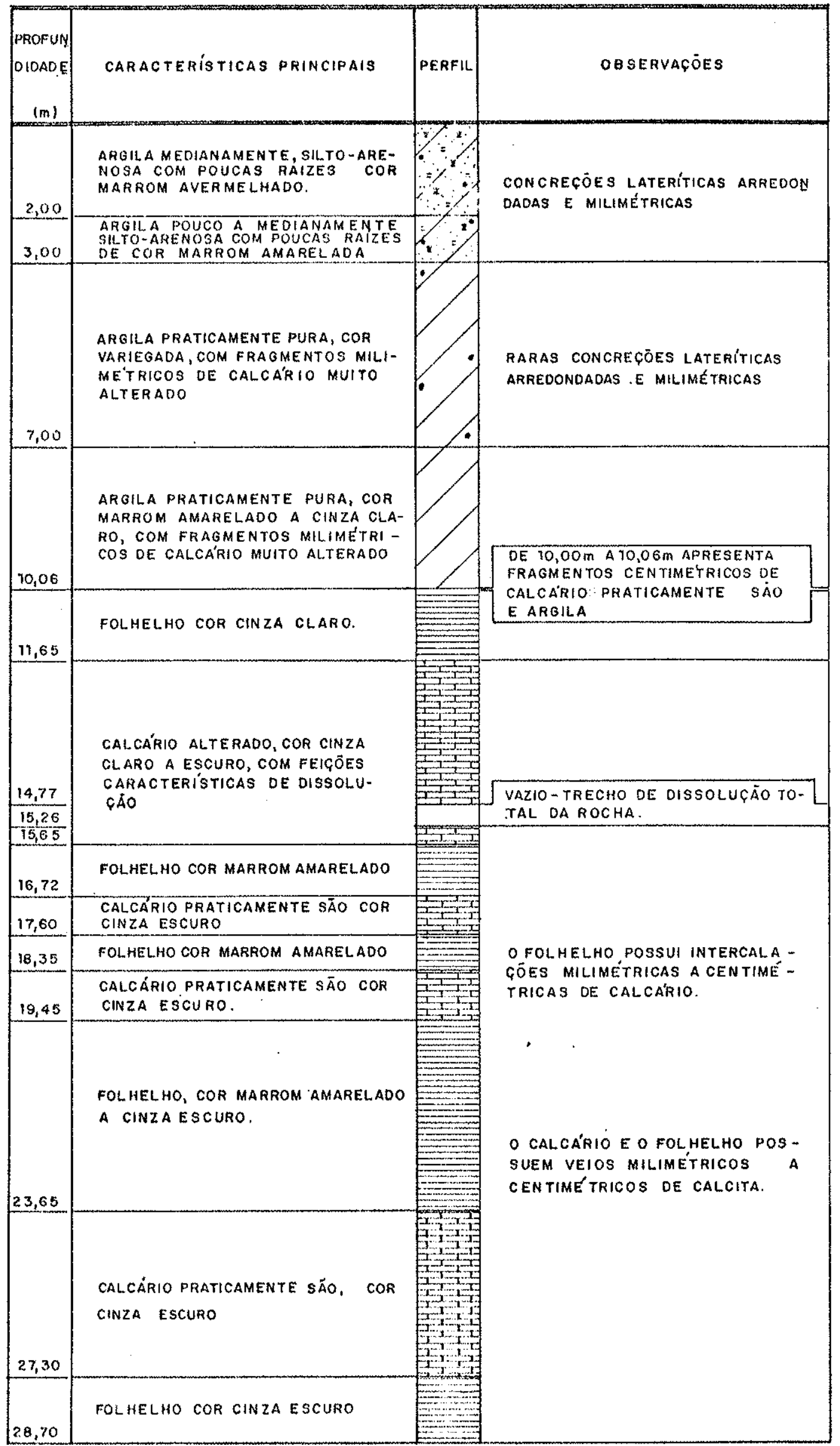

Fig. 4 - Perfil de sondagern em sedimentos coluvionares 
dagens profundas ilustrando a distribuição litolögica encontrado na região. Essas sondagens foram realizadas respectivamente sobre os sedimentos aluvionares e colu vionares.

A Formação das Vazantes, representada por depōs $\underline{i}$ tos arenosos e argilosos inconsolidados, nas mais va riadas proporções, $\bar{e}$ de origem fluvial. 0 enriquecimen to de concreções ferromanganiferas e acumulações argilo sas vermelhas na sua parte superior indicam a ocorrẹn cia de fenômenos de ferralitização, posterior à sua de posição.

os depösitos coluvionares são predominantemente ar gilosos, com pouca areia e espessura que varia entre 1 e 8 metros, diminuindo à medida que se aproxima das ro chas aflorantes. Sua origem estā relacionada $\bar{a}$ desagre gação física e quỉmica das rochas da Formação sete La goas, e transporte por gravidade.

Mais recentemente depositaram-se às margens do rio São Francisco, acompanhando o seu curso, sedimentos alu vionares areno-argilosos relacionados com a atual pla nîcie de inundação.

\subsubsection{Geomorfologia}

A região estudada caracteriza-se, a partir do rio São Francisco, pela existencia de 3 níveis de terraços (inferior, intermediärio e superior), ligados a āreas 
elevadas por meio de um "glacis". A FIGURA 2 ilus tra os diferentes compartimentos geomorfologicos da re gião.

0 primeiro terraço situa-se entre as cotas de 440 $m$ e $443 \mathrm{~m}$, distribuindo-se às margens do rio são Fran cisco. Parte desse terraço permanece, boa parte do pe rĩodo chuvoso, inundado pelas äguas do São Francisco.

0 segundo terraço, situado entre as cotas de $451 \mathrm{~m}$ e $453 \mathrm{~m}, \mathrm{na} o$ apresenta sinais de inundação. Apresenta superficie plana coberta por areias finas a medias pra ticamente puras.

o terceiro terraço, ou superior, situa-se entre as cotas de $462 \mathrm{~m}$ e $480 \mathrm{~m}$, sendo coberto por areias finas e médias com teores relativamente mais elevados de argi las vermelhas. Conforme citado anteriormente, este ter raço liga-se gradativamente a elevações rochosas por meio de um pedimento coluvionar.

As äreas mais elevadas, representadas por morros isolados, correspondem a testemunhos poupados à erosão que, de maneira notävel, atuou em toda a região.

A superficie, tanto dos terraços como do "glacis", caracteriza-se por topografia praticamente plana inter rompida pela presença localizada de depressões superfí ciais e vales de riachos afluentes do São Francisco. Es tes vales apresentam-se secos, notando-se apenas, duran te a ēpoca de chuvas, algumas surgēncias d'ägua que não 
chegam a constituir cursos d'ägua.

As depressões superficiais apresentam dimensões, formas e profundidades variadas, sendo, em função de suas profundidades classificadas em:

- classe A: depressões superficiais com profundidade de atē 3 metros;

- classe B: depressões superficiais com profundidade en tre 3 e 5 metros;

- classe $C$ : depressões superficiais com profundidade maior que 5 metros.

A origem dessas depressões estā relacionada ao aba timento do substrato calcärio promovido pela existência de estruturas cārsticas, detectadas atravēs de sonda gens profundas, realizadas tanto sobre os sedimentos alu vionares da Formação das Vazantes, como sobre os sedi mentos coluvionares ocorrentes no "glacis". Dois perfis ilustrativos dessas sondagens estão apresentados nas $f \underline{i}$ guras 3 e 4 .

\subsubsection{Pedologia}

Os critērios adotados para a caracterização pedoló gica foram os definidos pela EMBRAPA/EPAMIG/RURALMINAS, 1976, apresentados no trabalho: "Levantamento de reco nhecimento com detalhes dos solos no Distrito Agroindus 
trial cio Jaíba - MG", cujo mapa pedológico foi elabora do en escala 1:125 000.

As unidades definidas para a região, sendo analisa das conforme critërios da FAO (in Melfi e Pedro, 1977), podem ser compreendidas e agrupadas da seguinte maneira:

a) solos caracterizados por alteração praticamente to tal: Latosol Vermetho Escuro distrófico (LED) e Lato sol Vermelho Amarelo diströfico (LVd);

b) solos caracterizados por alteração incompleta; Camb $\underline{i}$ sol eutröfico (Ce), e Litosol eutröfico (Re);

c) solos caracterizados por rocha mãe particular: Areias Quartzosas diströficas (AQd);

d) solos caracterizados por ausência de alteração: Solos Aluviais eutrōficos (Ae).

A FIgURA 5 mostra a distribuição das vārias uni dades pedológicas encontradas na região. As principais caracteristicas de distinção entre essas unidades serão a seguir descritas.

A - Solos caracterizados por alteração praticamente to tal

Estes solos apresentam em comum a presença de um horizonte $B$ latossólico, compreendendo dois tipos pedo 


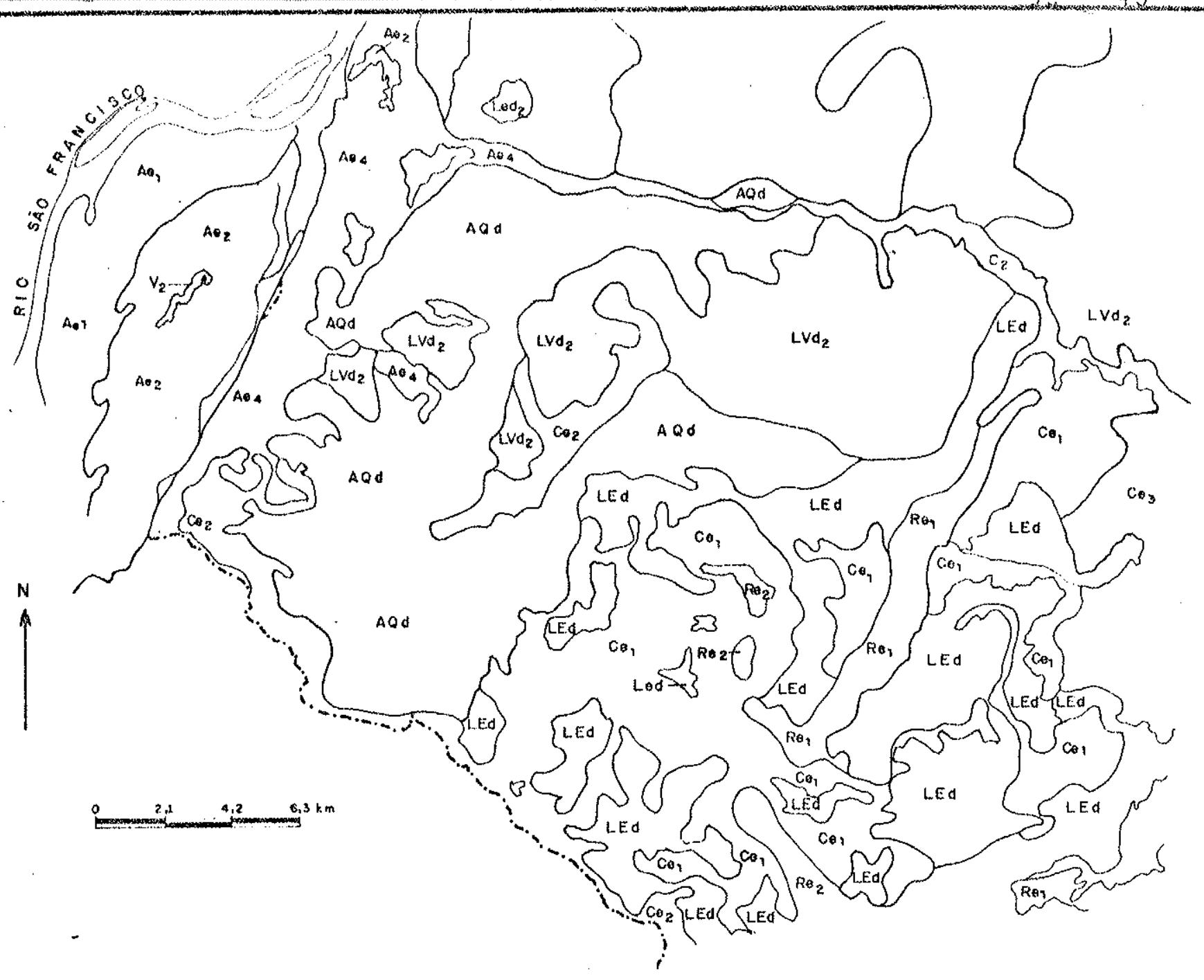

LEGENDA DE IDENTIFICAÇĀO DOS SOLOS

\begin{tabular}{|c|c|}
\hline$L V d_{2}$ & 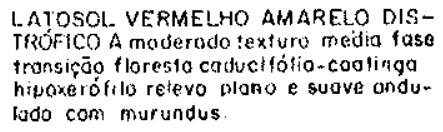 \\
\hline$v_{2}$ & $\begin{array}{l}\text { VERTISOL. A froco texturo orgilosa. } \\
\text { fose floresta perenifólía de vórzeo- } \\
\text { relevo plano. }\end{array}$ \\
\hline LE $d$ & 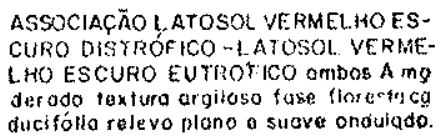 \\
\hline $\mathrm{Col}$ & 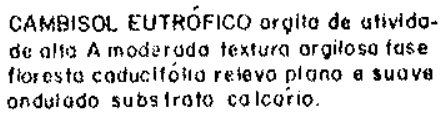 \\
\hline$C .2$ & 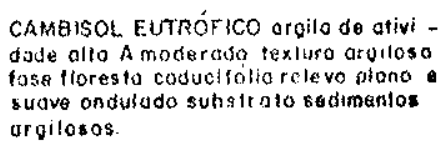 \\
\hline$C=3$ & 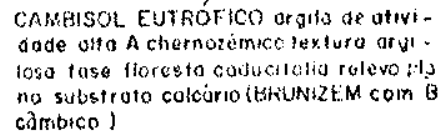 \\
\hline
\end{tabular}
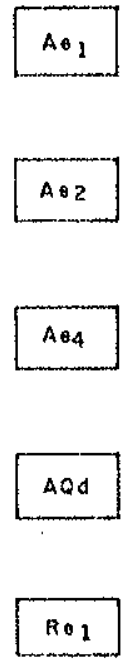

SOL OS ALUVIAIS EUTRÓFICCS A moderado texiuro arailosa fose flaresita dorenifolio e compos de varzea ralevo su ave ondulado e piano.

SOLOS ALUVIAIS EUTROFICOS imper feltamente drenodos A froco e mootado textura or giloso fose coatingo hipo. xerófilu e compos de varzeo relevo plano.

SOLOS ALUVIAIS FUTRÓFICOS A mo derodo texturo arenoso fose fluresta subcaducifótlu e campos antróplcos relevo plano e sugve ondulodo.

AREIAS QUARTZOSAS DISTRTFICAS A moderoto fose cautingo hipakarólilu re levo plono e sueve ondukado.

ASSOCIACT̃O DE SOLOS LITÓLICOS EUTRUFICOS fose coatinqa hinoxeró filo "hiperxerófila + CAMEISOI EU.

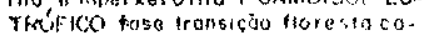
ducitólfo coolingu hiboxerótita un ducitolfo cadingu hiboxerofita um bos regita da alividuda alla nouda

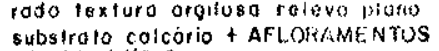
DE CALCARIO.

ASSOCIACÄO OE SOLOS LITÓLICOS EUTRÓficos fase tonsicion tintusta corsucifolio. cuationg tapeneriofliso 1. CAMbisOr EUThOFico fase to. restu coducíalio ambos aralla de alividado ollo, A mosorode lenturo

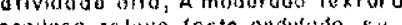
arging roluvi RAMENTOS UE CALCAMIO $E$ fOL.HIE L.HO 
Iogicos: Latosol Vermelho Escuro com textura argilosa e Latosul Vermelho Amarelo com textura média.

A distinção principal entre esses dois grandes gru pos de solos deve-se a algumas particularidades pedoge nēticas desenvolvidas sob a influência principalmente do substrato e posição no relevo. Enquanto o Latosol Vermelho Escuro ocorre sobre depösitos coluvionares ar gilosos influenciados pela composição carbonätica do substrato rochoso, o Latosol Vermelho Amarelo distribui -se sobre o terraço aluvionar mais antigo (terraço supe rior) cujo substrato pedogenētico ē basicamente consti tuĩdo por areias quartzosas praticamente puras.

- Latosol Vermetho Escuro distrófico (LEd)

ocorre associado a depösitos coluvionares, caracte rizando-se por sequência de horizonte $A, B$ e $C$ pouco di ferenciada, que se desenvolveram a partir de materiais argilosos, provenientes de calcārios. A Foto 1 mos tra uma ärea de ocorrência desses solos, notando-se a presença de "murundus" em superficie, comumente associa dos aos latosolos da região.

São solos acentuadamente drenados, argilosos, muito porosos com permeabilidade e friabilidade elevada. Sua quantidade em silte é elevada, contradizendo com a sua natureza latossölica; provavelmente tal fato se de ve a uma dispersão incompleta da argila, durante a rea lizaçäo dos ensaios de laboratörio. 


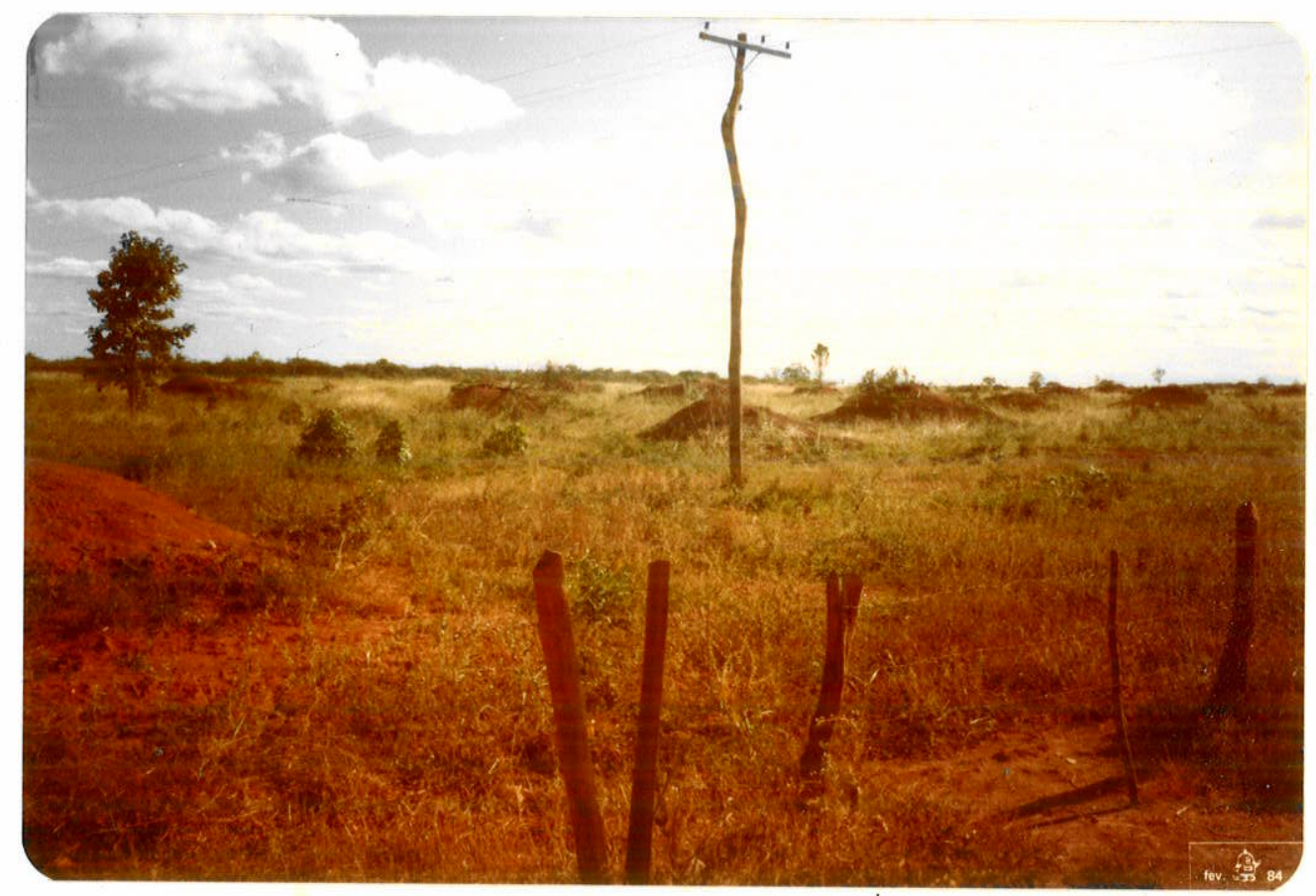

FOTO 1 - Paisagem de ocorrēncia do Latosol Vermelho Escuro dis trōfico (LEd). Notar a grande incidência do "Murundus" disper samente distribuĩdos na superfície do terreno. Estrada Mocam binho Janaūba, km 65 . 
Ao longo do perfil observa-se distribuição unifor me e dispersa de concreçöes milimētricas de öxido de fer ro e manganès.

0 horizonte $B \bar{e}$ relativamente espesso, podendo atin gir espessura de atē 3 metros; são muito argilosos, com teores em torno de $70 \%$.

As TABELAS 2 e 3 apresentam resumidamente as principais caracteristicas fisicas e quimicas desses so 10s. Conforme pode ser verificado, estes solos são mui to äcidos, apresentam valores de soma de bases inferio res a 2, baixa atividade das argilas, e baixa saturação de bases.

- Latosol Vermetho Amarezo distrófico (LVd)

Distribui-se no terraço superior associado a sedi mentos aluvionares da Formação das Vazantes, cuja cons tituição minera lögica ex extremamente pobre, formada qua se que exclusivamente por quartzo. A FoTo 2 mostra a parte superior de um perfil desse solo:

As TABELAS 4 e $5^{\circ}$ apresentam resumidamente as principais caracteristicas físicas e quimicas desses so los, notando-se muita similaridade quanto as proprieda des quîmicas em relação ao Latosol Vermelho Escuro dis tröfico. Neste sentido, são tambēm solos muito äcidos, apresentando baixos valores de soma de bases, de ativi dade das argilas e de saturação de bases. 


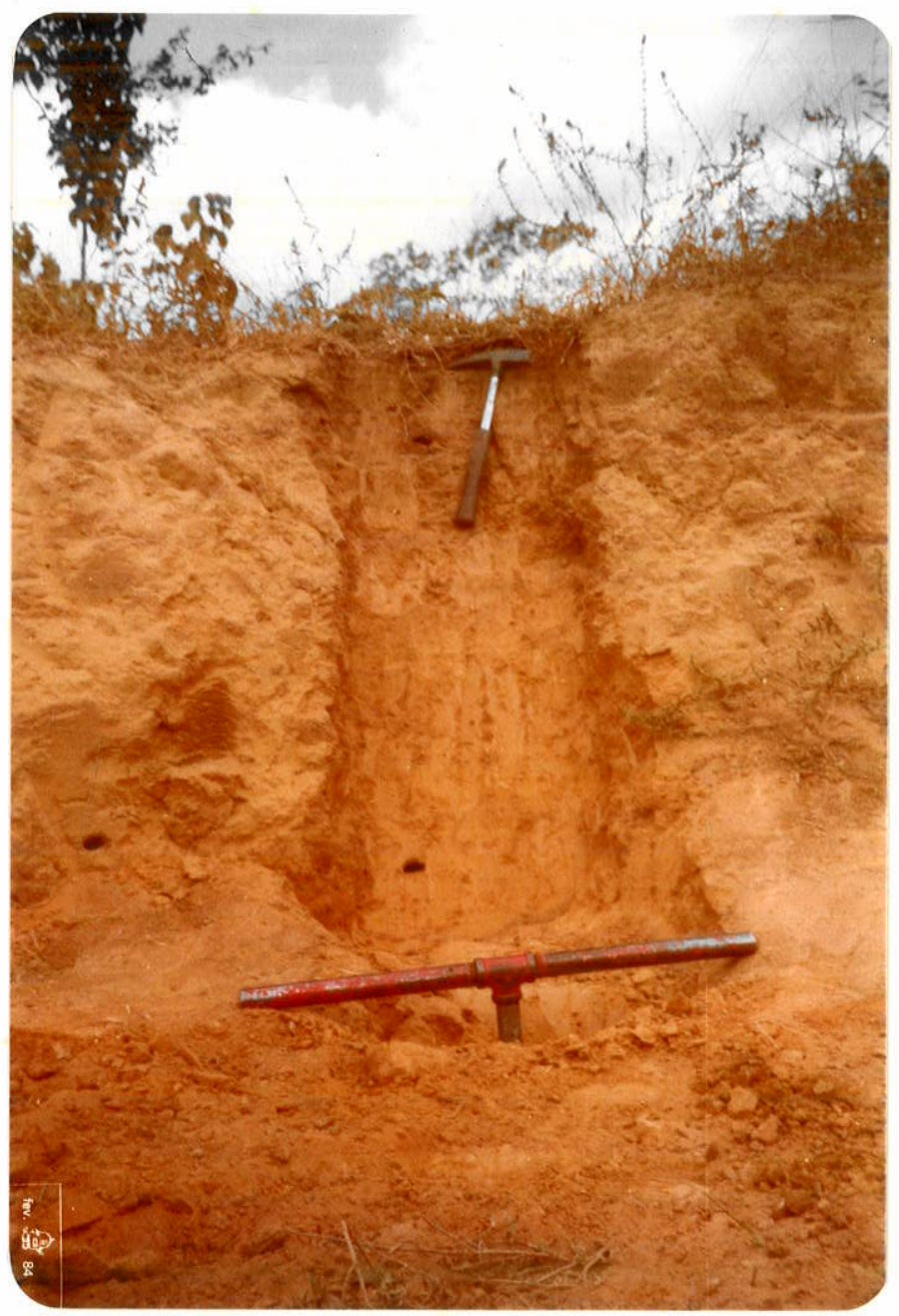

FOTO 2 - Corte mostrando perfil de Latosol Vermelho Amaredo distrōfico (LVd). Estrada Mocambinho - Jaība. 
TABELA 2 - Caracteristicas físicas principais do Latosol Vermelho Escuro distrófico (LEd) obtidas segundo EMBRAPA/EPAMIG/RURALMINAS, 1976

\begin{tabular}{|c|c|c|c|c|c|c|c|c|c|c|c|}
\hline \multicolumn{2}{|c|}{ Horizontes } & \multicolumn{4}{|c|}{$\begin{array}{c}\text { Composição Granulométrica } \\
(\%)\end{array}$} & \multirow{2}{*}{$\begin{array}{l}\text { Argila } \\
\text { Natural } \\
(\%)\end{array}$} & \multirow{2}{*}{$\begin{array}{l}\text { Grau de } \\
\text { Flocula- } \\
\text { ção }(\%)\end{array}$} & \multirow{2}{*}{$\begin{array}{l}\text { Relação } \\
\text { Silte/ } \\
\text { Argilla }\end{array}$} & \multicolumn{2}{|c|}{ Densidade } & \multirow{2}{*}{$\begin{array}{c}\text { Porosidade } \\
\text { (\%) }\end{array}$} \\
\hline Simb. & $\begin{array}{l}\text { Prof. } \\
\text { (cm) }\end{array}$ & $\begin{array}{l}\text { Areia } \\
\text { Grossa }\end{array}$ & $\begin{array}{l}\text { Areia } \\
\text { Fina }\end{array}$ & Silte & Argila & & & & Apar. & Real & \\
\hline$A_{1}$ & $0-15$ & 4 & 5 & 22 & 69 & 25 & 64 & 0,32 & 1,04 & 2,38 & 56 \\
\hline$A_{3}$ & $15-51$ & 3 & 5 & 23 & 69 & 8 & 88 & 0,33 & 1,01 & 2,46 & 59 \\
\hline $\mathrm{B}_{1}$ & $51-102$ & 2 & 4 & 20 & 74 & 1 & 97 & 0,27 & 1,06 & 2,45 & 57 \\
\hline $\mathrm{B}_{22}$ & $102-155$ & 3 & 5 & 21 & 71 & 0 & 100 & 0,30 & 1,05 & 2,61 & 60 \\
\hline $\mathrm{B}_{23}$ & $155-200$ & 3 & 4 & 20 & 73 & 0 & 100 & 0,27 & 1,12 & 2,76 & 59 \\
\hline
\end{tabular}


TABELA 3 - Caracteristicas quimicas principais do Latosol Vermelho Escuro Diströfico (LEd) obtidas segundo EMBRAPA/EPAMIG/RURALMINAS, 1976

\begin{tabular}{|c|c|c|c|c|c|c|c|c|c|c|c|c|c|c|c|c|c|c|c|c|c|}
\hline \multicolumn{2}{|c|}{ Horizontes } & \multicolumn{2}{|c|}{$\mathrm{pH}$} & \multicolumn{7}{|c|}{ Cätions Trocäveis (mE/100g) } & \multicolumn{2}{|r|}{$\begin{array}{c}\text { Saturação } \\
\text { de }\end{array}$} & \multicolumn{4}{|c|}{$\begin{array}{l}\text { Ataque por } \mathrm{H}_{2} \mathrm{SO}_{4} / \\
\text { Dens. } 1,47\left(\begin{array}{c}\% \\
\%\end{array}\right)\end{array}$} & \multicolumn{3}{|c|}{$\mathrm{SiO}_{2} / \mathrm{SiO}_{2} \mathrm{Si}_{2}$} & \multirow{2}{*}{$\begin{array}{l}c \\
(\not{x})\end{array}$} & \multirow[b]{2}{*}{$\begin{array}{l}N \\
\left(\begin{array}{l}N \\
\text { o }\end{array}\right)\end{array}$} \\
\hline Simb. & Prof. & Agua & $\mathrm{KCl}$ & H & Al & $\mathrm{Ca}$ & $\mathrm{Mg}$ & $k$ & $\mathrm{Ma}$ & $\begin{array}{l}\text { Soma } \\
\text { de base }\end{array}$ & C.T.C. & $\begin{array}{l}\text { Base } \\
\text { (\%) }\end{array}$ & $\mathrm{SiO}_{2}$ & $\mathrm{Al}_{2} \mathrm{O}_{3}$ & $\mathrm{Fe}_{2} \mathrm{O}_{3}$ & $\mathrm{TiO}_{2}$ & $\mathrm{P}_{2} \mathrm{O}_{5}$ & $\begin{array}{l}\mathrm{Al}_{2} \mathrm{O}_{3} \\
(\mathrm{Ki})\end{array}$ & $\begin{array}{l}\mathrm{Fe}_{2} \mathrm{O}_{3}+ \\
(\mathrm{Kr})^{+}\end{array}$ & & \\
\hline$A_{1}$ & $0-15$ & 4,3 & 3,6 & 4,0 & 3,6 & 0,8 & 0,4 & 0,19 & 0,01 & $.1,4$ & 9,0 & 16 & 26,7 & 21,7 & 11,6 & 0,54 & 0,03 & 2,09 & 1,56 & 1,13 & 0,15 \\
\hline$A_{3}$ & $|5-5|$ & 3,9 & 3,6 & 4,2 & 3,8 & 0,8 & 0,5 & 0,14 & 0,03 & 1,5 & 9,5 & 16 & 29,3 & 22,8 & 11,7 & 0,48 & 0,05 & 2,19 & 1,64 & 1,05 & 0,13 \\
\hline 81 & $51-102$ & 4,4 & 3,8 & 2,2 & 3,4 & 0,7 & 0,4 & 0,05 & 0,02 & 1,2 & 6,8 & 18 & 29,5 & 24,1 & 11,9 & 0,53 & 0,03 & 2,07 & 1,58 & 0,33 & 0,08 \\
\hline${ }^{B} 22$ & $102-155$ & 4,3 & 3,7 & 2,0 & 3,6 & 0,6 & 0,3 & 0,07 & 0,02 & 1,0 & 6,6 & 15 & 30,5 & 23,6 & 11,8 & 0,55 & 0,03 & 2,19 & 1,67 & 0,30 & 0,07 \\
\hline $\mathrm{B}_{23}$ & $155-260$ & 4,3 & 3,6 & 3,0 & 4,0 & 0,7 & 0,3 & 0,06 & 0,02 & 1,1 & 8,1 & 14 & 32,8 & 24,5 & 12,4 & 0,59 & 0,03 & 2,28 & 1,72 & 0,20 & 0,06 \\
\hline
\end{tabular}


TABELA 4 - Caracteristicas físicas principais do Latosol Vermelho Amarelo diströfico (LVd) obtidas segundo EMBRAPA/EPAMIG/RURALMINAS, 1976

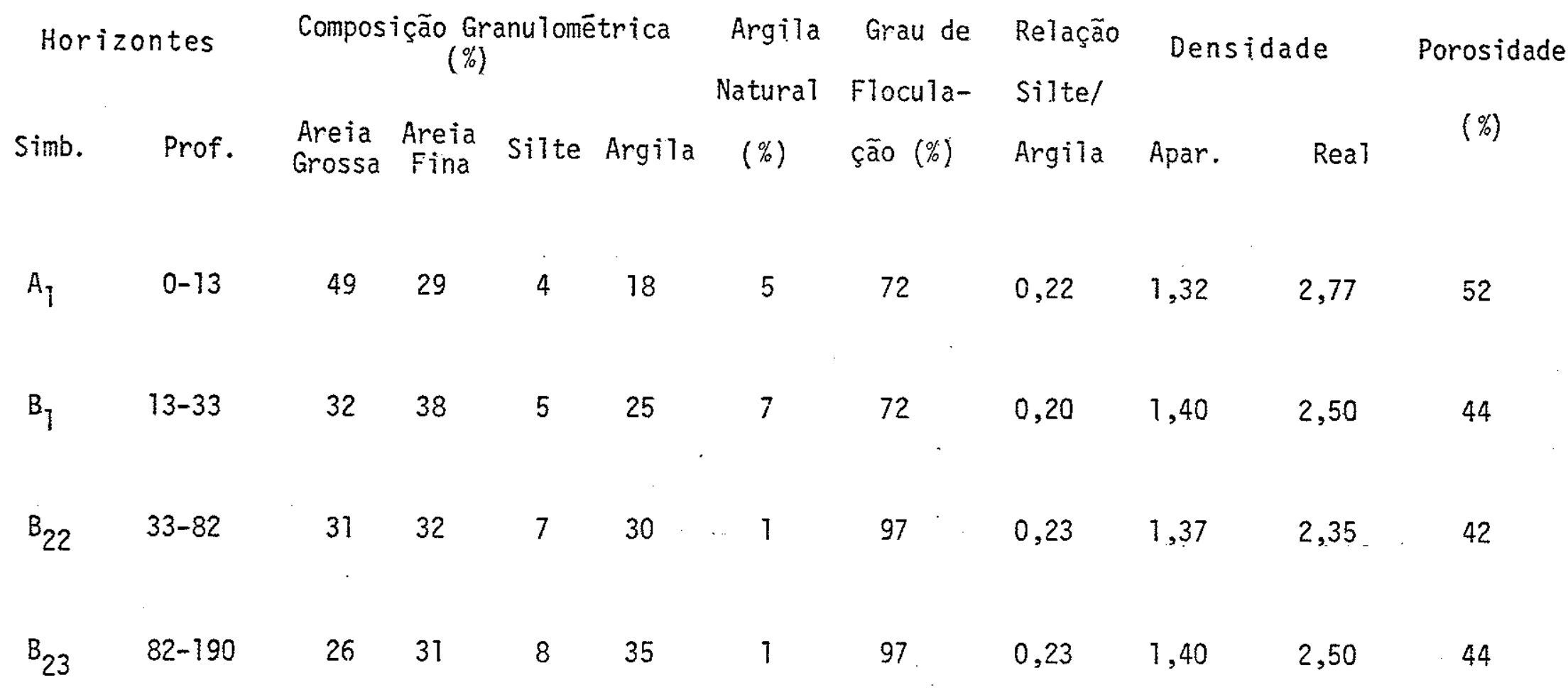


TABELA 5 - Caracteristicas quimicas principais do Latosol Vermelho Amarelo distrófico (LVd) obtidas segundo EMBRAPA/EPAMIG/RURALMINAS, 1976

\begin{tabular}{|c|c|c|c|c|c|c|c|c|c|c|c|c|c|c|c|c|c|c|c|c|c|}
\hline \multicolumn{2}{|c|}{ Morizontes } & \multirow{2}{*}{$\begin{array}{l}\mathrm{pH} \\
\text { Agua }\end{array}$} & \multirow{2}{*}{ KC1 } & \multicolumn{8}{|c|}{ Cátions trocāveis (mE/100g) } & \multirow{2}{*}{$\begin{array}{l}\text { Saturação } \\
\text { de } \\
\text { base } \\
(\%)\end{array}$} & \multicolumn{5}{|c|}{ Ataque por $\mathrm{H}_{2} \mathrm{SO}_{4}$} & \multirow{2}{*}{$\begin{array}{l}\mathrm{SiO}_{2} \mathrm{I} \\
\mathrm{Ai}_{2} \mathrm{O}_{3} \\
\\
(\mathrm{Ki})\end{array}$} & \multirow{2}{*}{$\begin{array}{l}\mathrm{SiO}_{2} \mathrm{I} \\
\mathrm{Al}_{2} \mathrm{O}_{3}+ \\
\mathrm{Fe}_{2} \mathrm{O}_{3} \\
(\mathrm{Kr})\end{array}$} & \multirow{2}{*}{$\begin{array}{l}C \\
(x)\end{array}$} & \multirow{2}{*}{$\begin{array}{l}N \\
(\$)\end{array}$} \\
\hline Simb. & Prof. & & & $H$ & Al & $\mathrm{Ca}$ & $\mathrm{Mg}$ & $k$ & $\mathrm{Na}$ & $\begin{array}{l}\text { dema } \\
\text { bases }\end{array}$ & C.T.C. & & $\mathrm{SiO}_{2}$ & $\mathrm{Al}_{2} \mathrm{O}_{3}$ & $\mathrm{Fe}_{2} \mathrm{O}_{3}$ & $\mathrm{TiO}_{2}$ & $\mathrm{P}_{2} \mathrm{O}_{5}$ & & & & \\
\hline$A_{1}$ & 0.13 & 5,0 & 4,0 & 2,9 & 0,9 & 1,4 & 0,4 & 0,14 & 0,02 & 2,0 & 5,8 & 34 & 8,0 & 7,9 & 2,0 & 0,38 & 0,02 & 1,73 & 1,48 & 1,0 & 0,10 \\
\hline$B_{1}$ & $13-33$ & 4,7 & 3,9 & 1,8 & 1,7 & 0,7 & 0,2 & 0,08 & 0,01 & 1,0 & 4,5 & 22 & 11,9 & 10,8 & 2,4 & 0,40 & 0,02 & 1,88 & 1,64 & 0,52 & 0,06 \\
\hline$B_{22}$ & $33-82$ & 4,8 & 3,9 & 1,8 & 1,5 & 0,7 & 0,3 & 0,03 & 0,01 & 1,0 & 4,3 & 23 & 13,6 & 12,4 & 2,8 & 0,52 & 0,01 & 1,87 & 1,63 & 0,20 & 0,04 \\
\hline${ }^{8} 23$ & $82-190$ & 4,8 & 3,8 & 1,3 & 1,6 & 0,7 & 0,3 & 0,03 & 0,01 & 1,0 & 3,9 & 26 & 15,0 & 14,9 & 3,0 & 0,60 & 0,01 & 1,71 & 1,52 & 0,19 & 0,03 \\
\hline
\end{tabular}


As principais diferenças entre o Latosol Vermelho Amaralo diströfico e o Latosol Vermelho Escuro diströf co referem-se às caracteristicas fïsicas, principalmen te texturais. 0 Latosol Vermelho Amarelo diströfico ē essencialmente arenoso, com mais de $50 \%$ de areia fina a grossa, e apresentando aumento progressivo de silte e argila em profundidade. Por outro lado, os teores em sil te são pouco expressivos, contrastando com o que se ob serva no Latosol Vermelho Escuro distrófico.

B - Solos caracterizados por alteração incompleta

Estes solos apresentam em comum uma quantidade sig nificativa de minerais primärios pouco intemperizados. distribuidos ao longo do perfil, sendo representados os seguintestipos pedolögicos: Cambisol eutröfico substrato sedimentos argilosos, Cambisol eutrófico fase substrato calcārio, Cambisol eutröfico com horizonte $A$ chernozê mico e Litosol eutrōfico.

os cambissolos caracterizam-se pela presença de um horizonte $B$ câmbico, coloração amarela avermelhada $e$ grande quantidade de minerais primärios principalmente na fração silte. Ocorrem em äreas rebaixadas, associan do-se normalmente às ocorrēncias de depressōes superfi ciais, comuns na região, conforme pode ser evidenciado nas FOTOS 3 e 4 . 


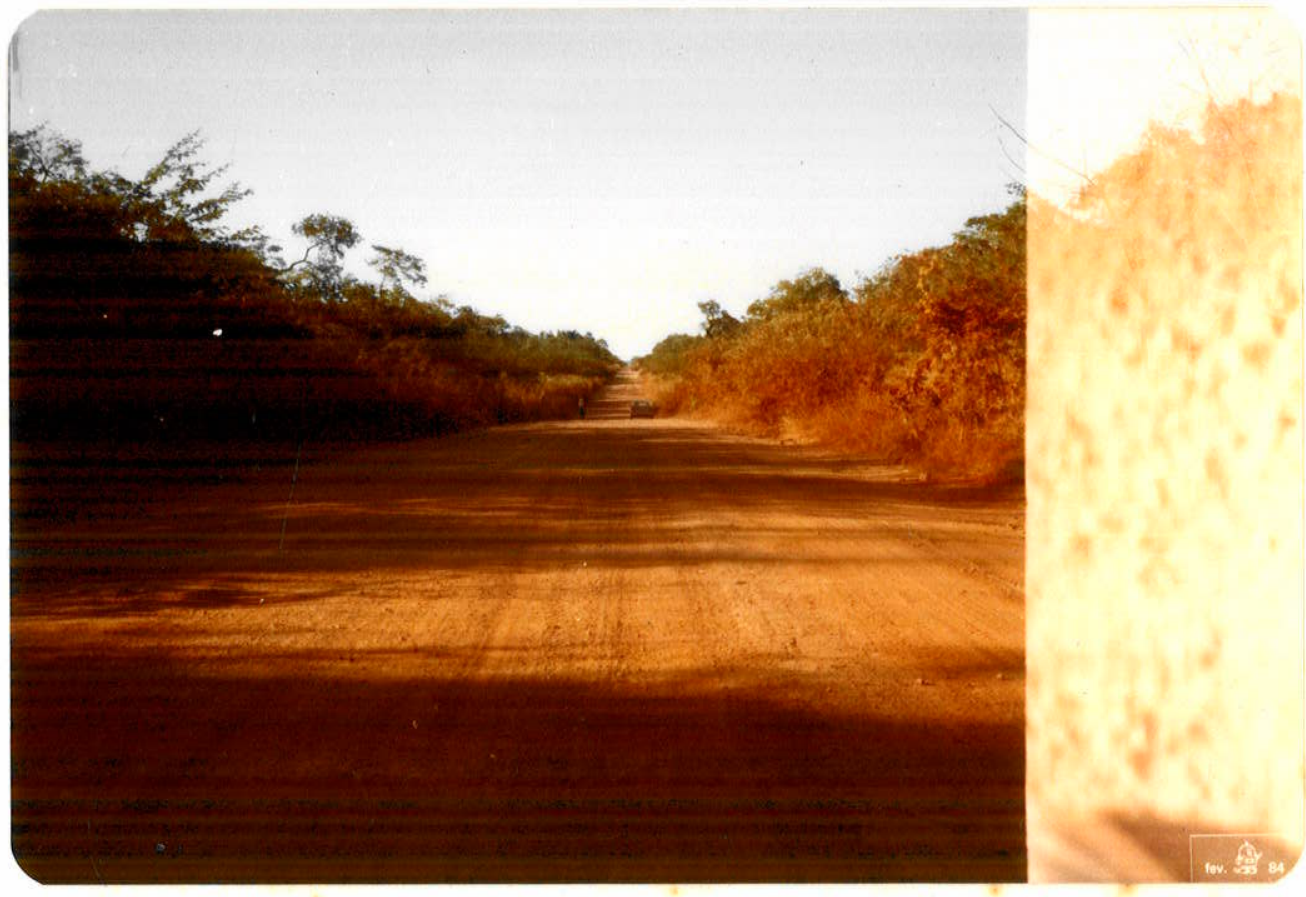

FOTO 3 - Vista geral do relevo em āreas de ocorrēncia do Lato sol Verme 1ho Amarelo distrófico (LVd) e do Cambisol eutrófico, ambos associados ao terraço superior. 0 Cambisol eutrófico $\left(\mathrm{Ce}_{2}\right)$ distribui-se na parte deprimida do terreno. Estrada Mo cambinho - Jaîba. 


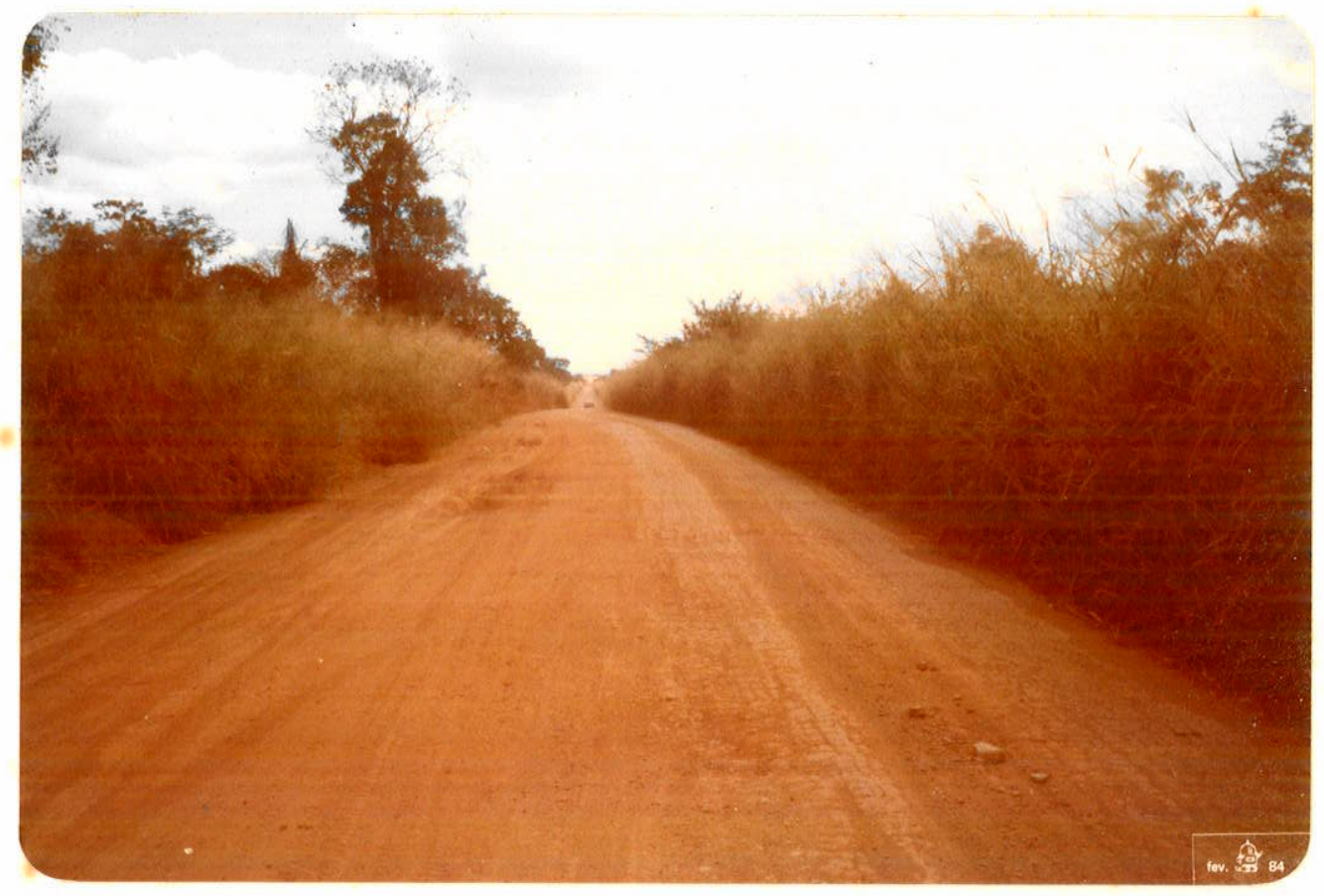

FOTO 4 - Vista geral do relevo em āreas de ocorrēncia do Lato sol Vermelho Escuro distrōfico (LEd) e Cambisol eutrōfico, as sociados a sedimentos coluvionares. O Cambisol eutröfico ( $\mathrm{Ce}_{1} \bar{\Gamma}$ distribui-se na parte deprimida do terreno. Estrada MocambinhoJaîba. 
Entre os cambissolos distinguem-se na região estu dada tềs subclasses cujas caracterîsticas principais são as seguintes:

- Cambisol eutrófico fase substrato calcário (Ce, )

0 Cambisol eutrōfico fase substrato calcārio dis tribui-se em äreas de ocorrēncia de sedimentos coluvio nares argilosos em locais rebaixados onde o substrato rochoso, constituido por calcārio, encontra-se a peque nas profundidades, normalmente pouco acima de 2,0 me tros. As FOTOS 5 e 6 mostram perfis representativos desses solos.

As TABELAS 6 e 7 apresentam resumidamente as caracteristicas físicas e quĩmicas desses solos, permi tindo as seguintes considerações:

- säo solos essencialmente argilo-siltosos ao lon go de todo o perfil, representando a fração fina teores superiores a $70 \%$. Observa-se entre os horizontes $A$ e $B$ um ligeiro aumento em profundidade nos teores de argila e diminuição nos teores de silte. Por outro lado, entre os horizontes B e C observa-se ao conträrio, uma lige ra diminuição nos teores de argila e aumento nos teores de silte. Conclui-se portanto pela existência de um cer to gradiente textural, provavelmente relacionado a apor te de material, tendo em vista a posição topogräfica que esses solos ocupan na paisagem. 


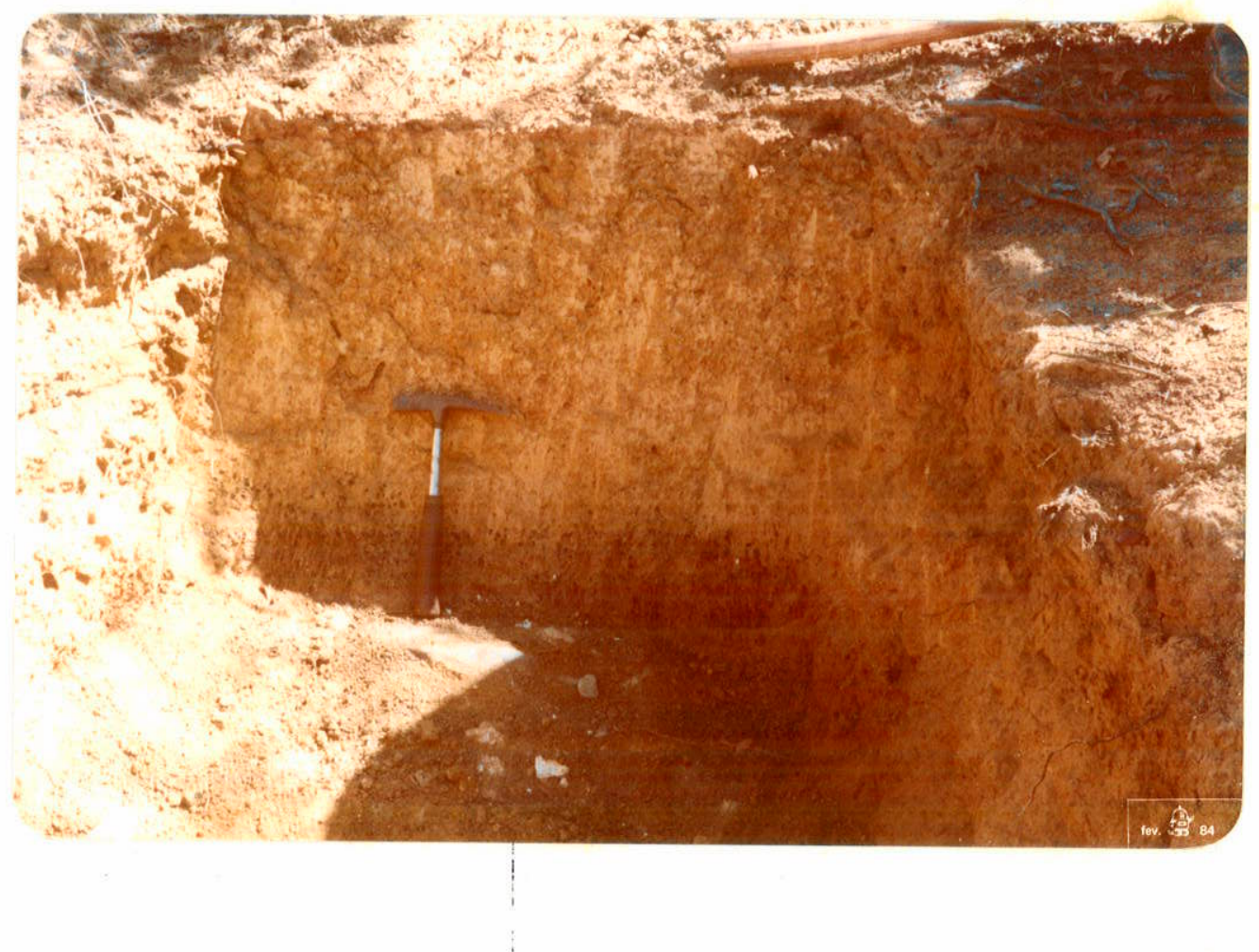

FOTO 5 - Trincheira mostrando perfil de Cambisol eutrōfico, substrato calcário ( $\left.\mathrm{Ce}_{1}\right)$. Notar a parte inferior do perfil, no contato com o substrato, com concentração de concreçōes de Timonita. Estrada Mocambinho - Jaība. 


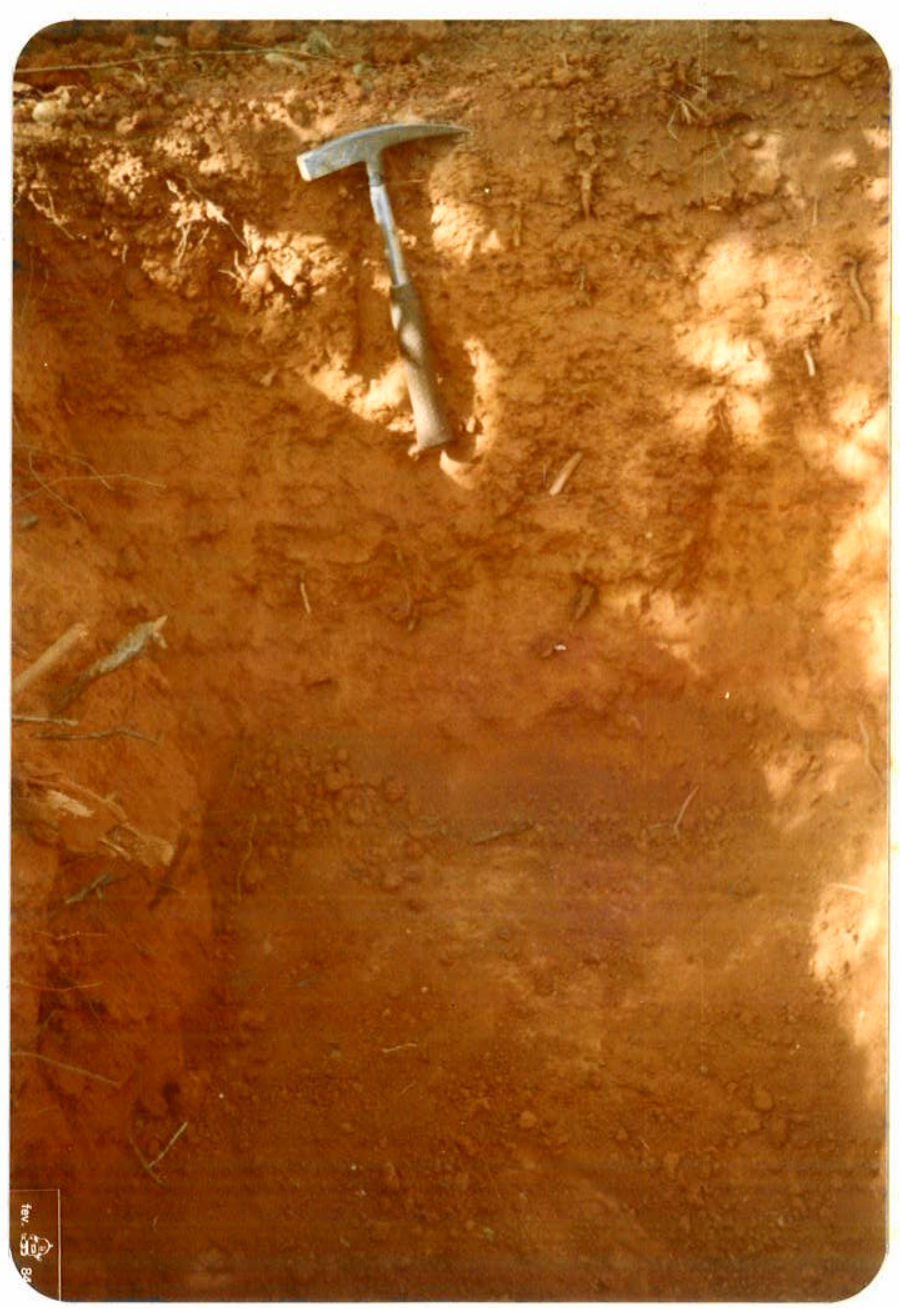

FOTO 6 - Trincheira mostrando perfil de Cam bisol eutrōfico ( $\mathrm{Ce}]$ ) em transição parā Latosol Vermelho Escuro distrōfico (LEd). Es trada Mocambinho-Jaỉba. 
TABELA 6 - Caracteristicas fásicas principais do Cambisol eutrófico fase substrato Calcá rio ( $\mathrm{Ce}_{1}$ ) obtidas segundo EMBRAPA/EPAMIG/RURALMINAS, 1976.

Horizontes Composição Granulomëtrica. Argila Grau de Relação Densidade Porosidade

Simb. Prof. Areia Areia Silte Argila (\%) ção (\%) Argila Apar. Real

$\begin{array}{llllllllllll}A_{1} & 0-5 & 16 & 18 & 37 & 29 & 14 & 52 & 1,30 & 1,35 & 2,44 & 45 \\ A_{3} & 5-20 & 16 & 16 & 30 & 38 & 23 & 39 & 0,79 & 1,31 & 2,40 & 45 \\ B_{1} & 20-35 & 12 & 13 & 27 & 48 & 24 & 50 & 0,56 & 1,44 & 2,65 & 46 \\ B_{2} & 35-125 & 13 & 13 & 26 & 48 & 14 & 71 & 0,54 & 1,36 & 2,80 & 51 \\ B_{3} & 125-165 & 13 & 14 & 29 & 44 & 3 & 93 & 0,66 & 1,36 & 2,61 & 48 \\ C & 165-190 & 11 & 15 & 33 & 41 & 6 & 85 & 0,80 & - & 2,44 & -\end{array}$


TABELA 7 - Caracteristicas quỉmicas principais do Cambisol eutrófico fase substrato calcá rio (Ce1) obtidas segundo EMBRAPA/EPAMIG/RURALMINAS, 1976

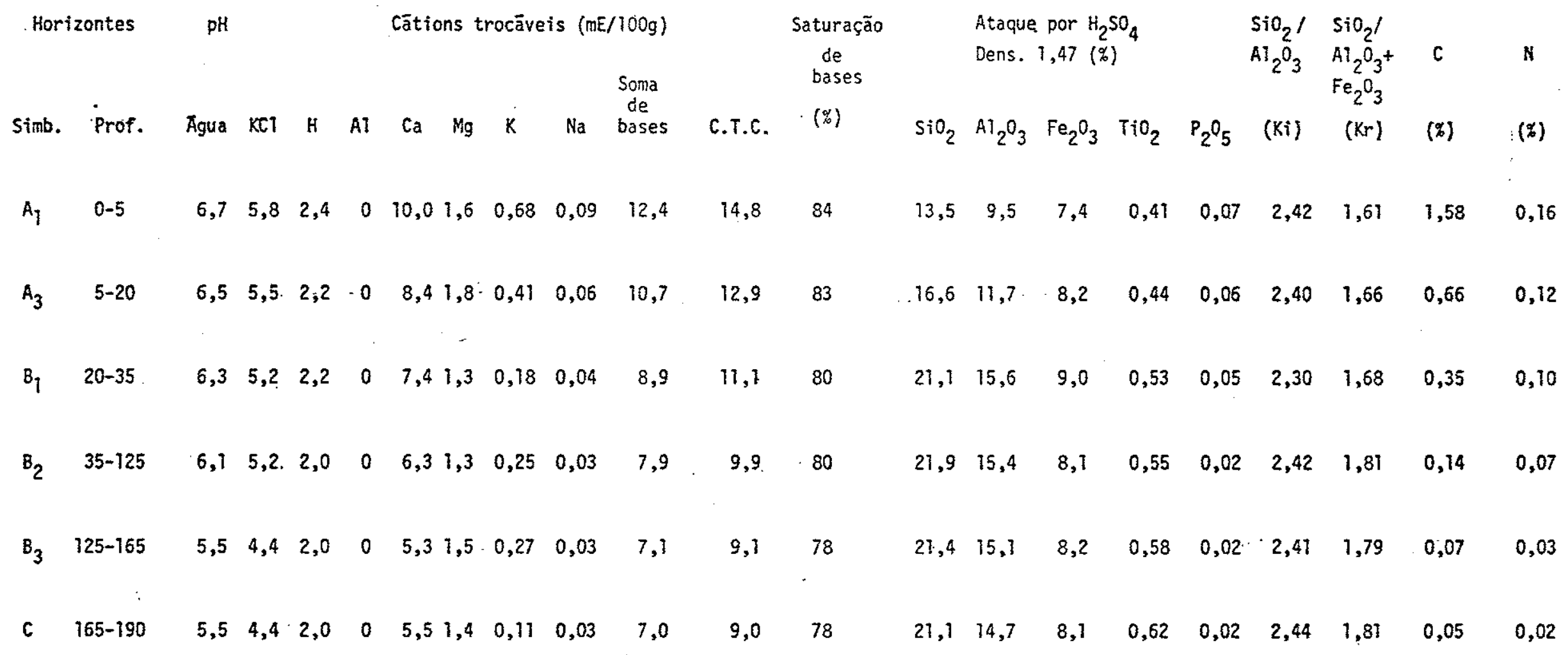


- são solos que apresentam relação silte/argila relatí vamente elevada ao longo de todo o perfil;

- apresentam-se relativamente bem drenados atē a base do horizonte B; esta condição de drenagem diminui à medida que se aproxima do horizonte $C$, tendo em vista a proxi midade do substrato calcārio. Em função dessa particula ridade è comum observar-se nas partes inferiores desses solos ocorrências de mosqueamento provocado por fenôme nos de redução.

- são solos pouco lixiviados apresentando em geral pH moderadamente àcido a neutro, relação Ki nọrmalmen te superior a 2,0 , e saturação de bases relativamente el evada.

- Cambisol eutrófico fase substrato sedimentos argiro$\operatorname{sos}\left(\mathrm{Ce}_{2}\right)$

0 Cambisol eutrófico fase substrato sedimentos ar gilosos distribui-se em āreas rebaixadas do terraço alu vionar mais elevado.

As Tabelas nọs 8 e 9 apresentam as características fïsicas e quimicas principais desses solos, evidencian do muita semelhança com Cambisol eutrōfico fase substra to calcārio, sendo vāilidas as mesmas consideraçães ante riormente descritas. 
TABELA 8 - Caracteristicas físicas principais do Cambisol eutrófico fase sedimentos argi sos $\left(\mathrm{Ce}_{2}\right)$ obtidas segundo EMBRAPA/EPAMIG/RURALMINAS, 1976.

\begin{tabular}{|c|c|c|c|c|c|c|c|c|c|c|c|}
\hline \multicolumn{2}{|c|}{ Horizontes } & \multicolumn{4}{|c|}{$\begin{array}{c}\text { Composição Granulomētrica } \\
(\%)\end{array}$} & \multirow{2}{*}{$\begin{array}{c}\text { Argila } \\
\text { Natural } \\
(\%)\end{array}$} & \multirow{2}{*}{$\begin{array}{l}\text { Grau de } \\
\text { Flocula- } \\
\text { ção (\%) }\end{array}$} & \multirow{2}{*}{$\begin{array}{l}\text { Relação } \\
\text { Silte/ } \\
\text { Argila }\end{array}$} & \multicolumn{2}{|c|}{ Densidade } & \multirow{2}{*}{$\begin{array}{l}\text { Porosid } \\
\qquad(\%)\end{array}$} \\
\hline Simb. & $\begin{array}{l}\text { Prof. } \\
\text { (cm) }\end{array}$ & $\begin{array}{l}\text { Areia } \\
\text { Grossa }\end{array}$ & $\begin{array}{l}\text { Areia } \\
\text { Fina }\end{array}$ & Silte & Argila & & & & Apar. & Real & \\
\hline$A p$ & $0-19$ & 7. & 19 & 48 & 26 & 13 & 50 & 1,84 & 1,17 & 2,43 & 52 \\
\hline$A_{3}$ & $19-32$ & 10 & 16 & 44 & 30 & 20 & 33 & 1,47 & 1,43 & 2,49 & 43 \\
\hline$B_{21}$ & $32-49$ & 6 & 12 & 32 & 50 & 35 & 30 & 0,64 & 1,49 & 2,53 & 41 \\
\hline$B_{22}$ & $49-103$ & 6 & 12 & 33 & 49 & $\cdots 42$ & 14 & 0,67 & 1,56 & 2,53 & 38 \\
\hline$B_{3}$ & $103-152$ & 5 & 10 & 46 & 39 & 5 & 87 & 1,18 & 1,66 & 2,54 & 35 \\
\hline
\end{tabular}


TABELA 9 - Caracteristicas quỉmicas principais do Cambisol eutrófico fase sedimentos argilosos (Ce2) obtidas segundo EMBRAPA/EPAMIG/RURALMINAS; 1976.

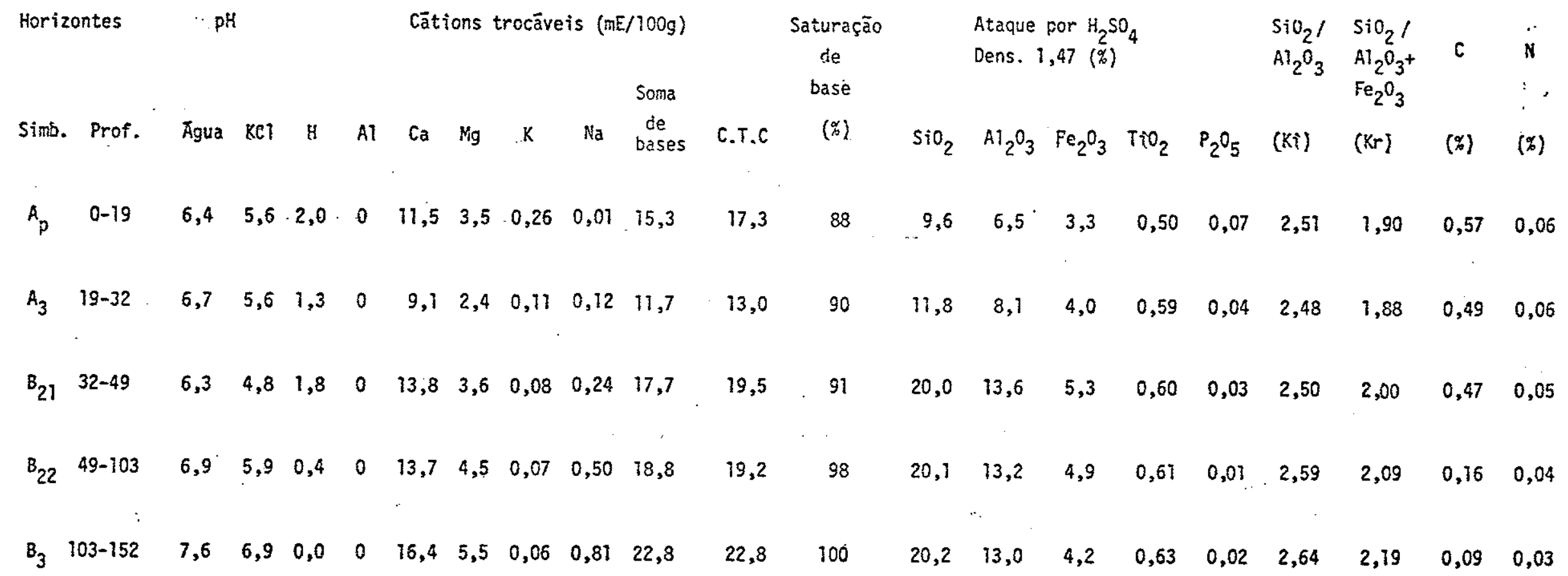


- Cambisol eutrófico com horizonte A Chernozêmico ( $\left.\mathrm{Ce}_{3}\right)$

ocorrem em äreas rebaixadas associadas aos depōsitos coluvionares. Apresentam caracteristicas morfolog cas, fisicas e quimicas muito semelhantes ao cambisol eutröfico fase substrato calcārio diferindo desta quan to as seguintes caracteristicas:

- espessura superior do horizonte $A$, que normalmente $\overline{\mathrm{a}}$ maior que $30 \mathrm{~cm}$;

- o horizonte C apresenta teores mais elevados de con creções limoniticas, normalmente cimentadas com argila.

- apresenta normalmente majores concentrações de öxidos de ferro distribuídos ao longo do perfil; em consequén cia, o Cambisol eutröfico com horizonte A Chernozêmico apresenta valores da relação $\mathrm{Al}_{2} \mathrm{O}_{3} / \mathrm{Fe}_{2} \mathrm{O}_{3}$ relativamente mais baixos;

- apresenta teores em carbono orgänico no horizonte A relativamente mais elevados.

As FOTOS 7 e 8 mostran perfis tipicos desses solos.

As TABELAS 10 e 11 apresentam resumidamente as principais características físicas e quĩmicas do Cambi sol eutröfico com horizonte A chernozêmico. 


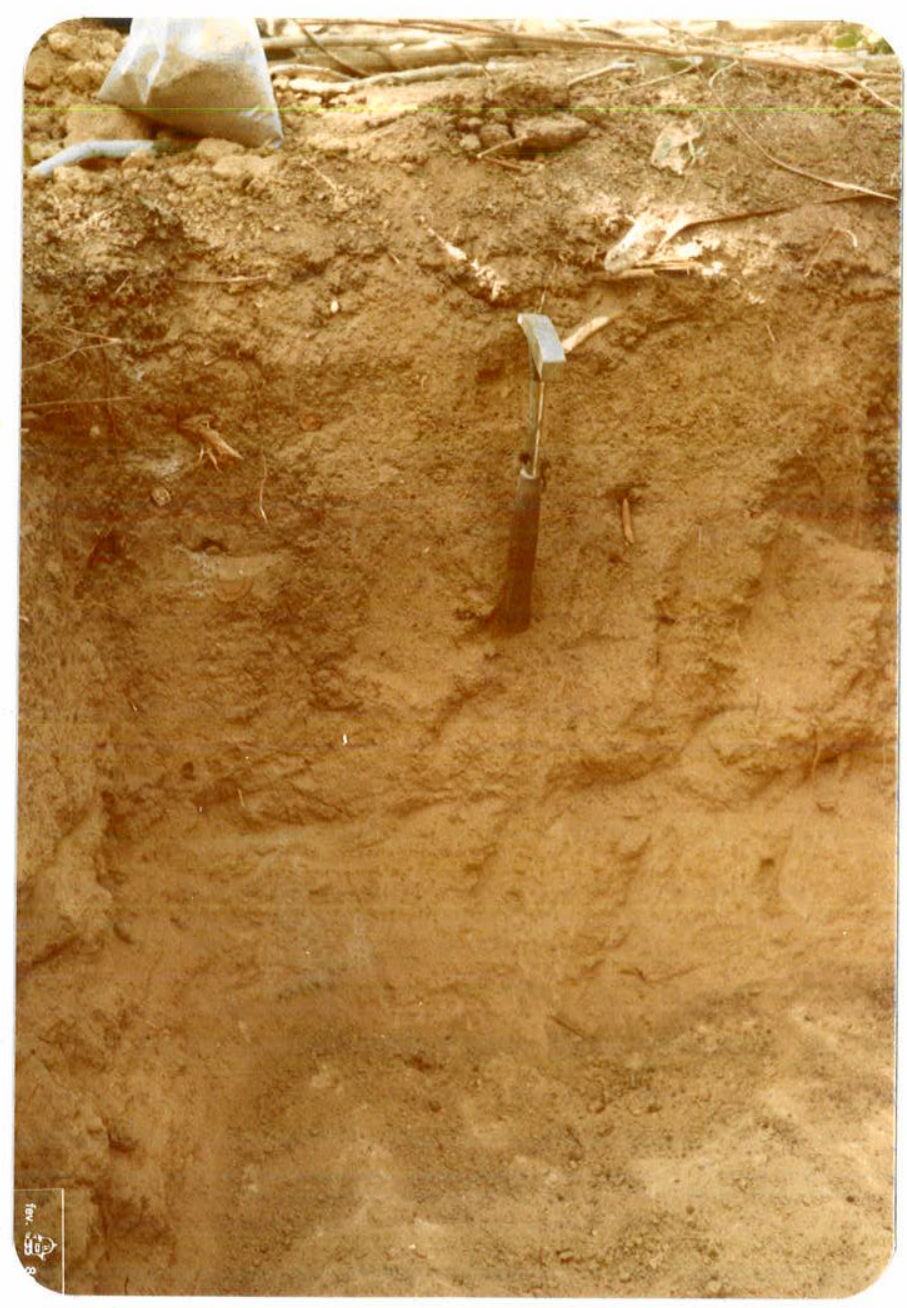

FOTO 7 - Trincheira mostrando perfil de Cam bisol eutrófico A Charnozêmico $\left(\mathrm{Ce}_{3}\right)$. ES trada Mocambinho-Jaĩba. 


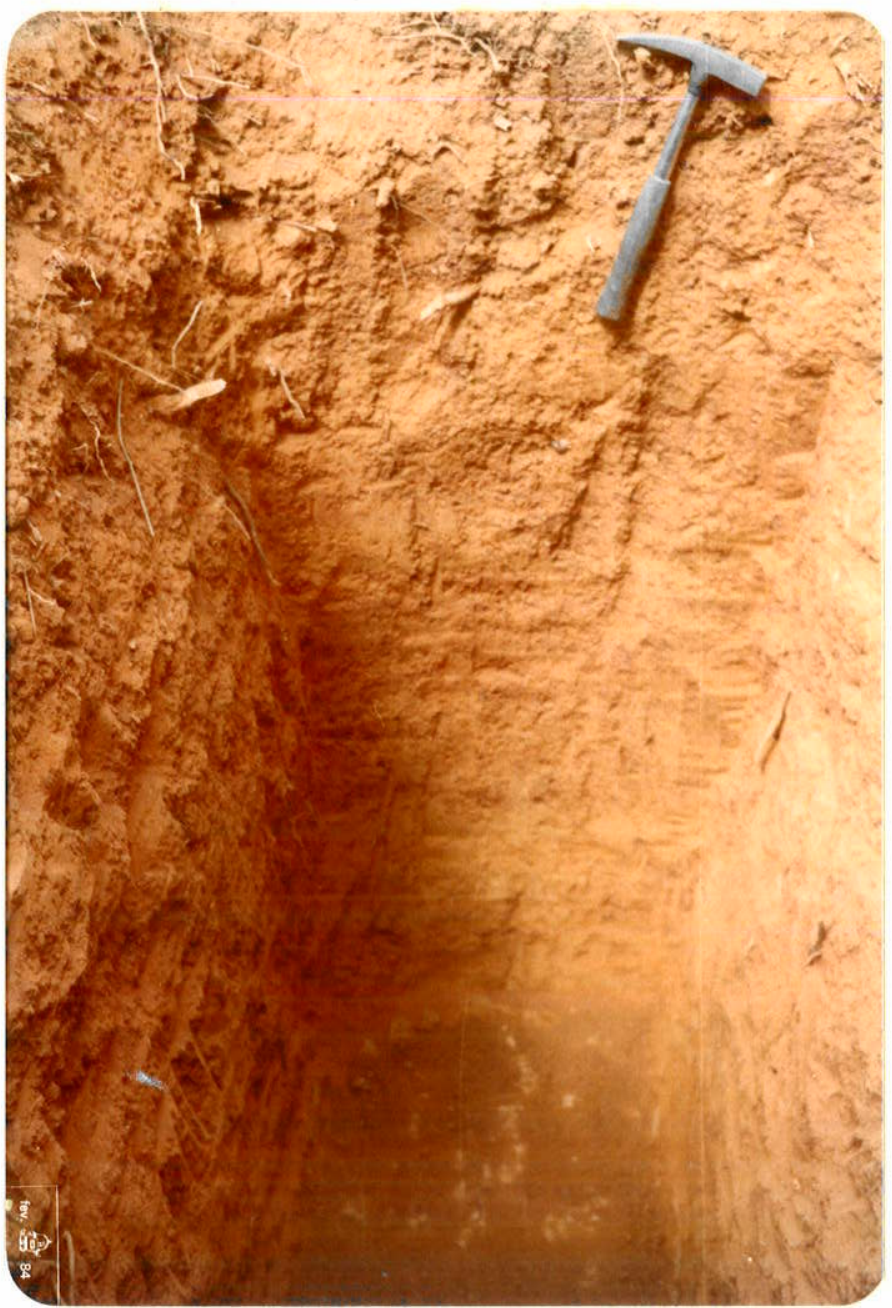

FОTO 8 - Trincheira mostrando perfil de Cam bisol eutrōfico A Chernozêmico $\left(\mathrm{Ce}_{3}\right)$ em transição para Latosol Vermelho Escuro dis tröfico (LEd). 
TABELA 10 - Características físicas principais do Cambisol eutröfico A Chernozémico ( $\mathrm{Ce}_{3}$ ). obtidas segundo EMBRAPA/EPAMIG/RURALMINAS, 1976.

\begin{tabular}{|c|c|c|c|c|c|c|c|c|c|c|c|}
\hline \multicolumn{2}{|c|}{ Horizontes } & \multicolumn{4}{|c|}{$\begin{array}{l}\text { Composição Granulométrica } \\
\qquad(\%)\end{array}$} & \multirow{2}{*}{$\begin{array}{c}\text { Argila } \\
\text { Natural } \\
(\%)\end{array}$} & \multirow{2}{*}{$\begin{array}{l}\text { Grau de } \\
\text { Flocula- } \\
\text { ção (\%) }\end{array}$} & \multirow{2}{*}{$\begin{array}{l}\text { Relação } \\
\text { Silte/ } \\
\text { Argila }\end{array}$} & \multicolumn{2}{|c|}{ Densidade } & \multirow{2}{*}{$\begin{array}{c}\text { Porosidade } \\
(\%)\end{array}$} \\
\hline Simb. & $\begin{array}{l}\text { Prof. } \\
(\mathrm{cm})\end{array}$ & $\begin{array}{r}\text { Areia } \\
\text { Grossa }\end{array}$ & $\begin{array}{l}\text { Areia } \\
\text { Fina }\end{array}$ & Silte & Argila & & & & Apar. & Real & \\
\hline$A_{1}$ & $0-10$ & 25 & 8 & 27 & 40 & 18 & 55 & 0,68 & 1,01 & 2,56 & 61 \\
\hline $\mathrm{A}_{3}$ & $10-31$ & 23 & 9 & 22 & 46 & 18 & 61 & 0,48 & 1,24 & 2,33 & 47 \\
\hline $\mathrm{B}_{22}$ & $31-62$ & 22 & 9 & 19 & 50 & 17 & 66 & 0,38 & 1,34 & 2,52 & 48 \\
\hline $\mathrm{B}_{23}$ & $62-108$ & 21 & 8 & 20 & 57 & 16 & 69 & 0,39 & 1,23 & 2,22 & 45 \\
\hline$c_{1}$ & $108-112$ & 33 & 6 & 16 & 45 & 14 & 69 & 0,36 & 1,30 & 2,58 & 50 \\
\hline$c_{2}$ & $112-180$ & 45 & 4 & 12 & 39 & 22 & 44 & 0,37 & 1,57 & 2,63 & 40 \\
\hline
\end{tabular}


TABELA 11 - Caracteristicas quimicas principais do Cambisol eutrófico A chernozémico
$\left(\mathrm{Ce}_{3}\right)$ obtidas segundo EMBRAPA/EPAMIG/RURALMINAS, 1976.

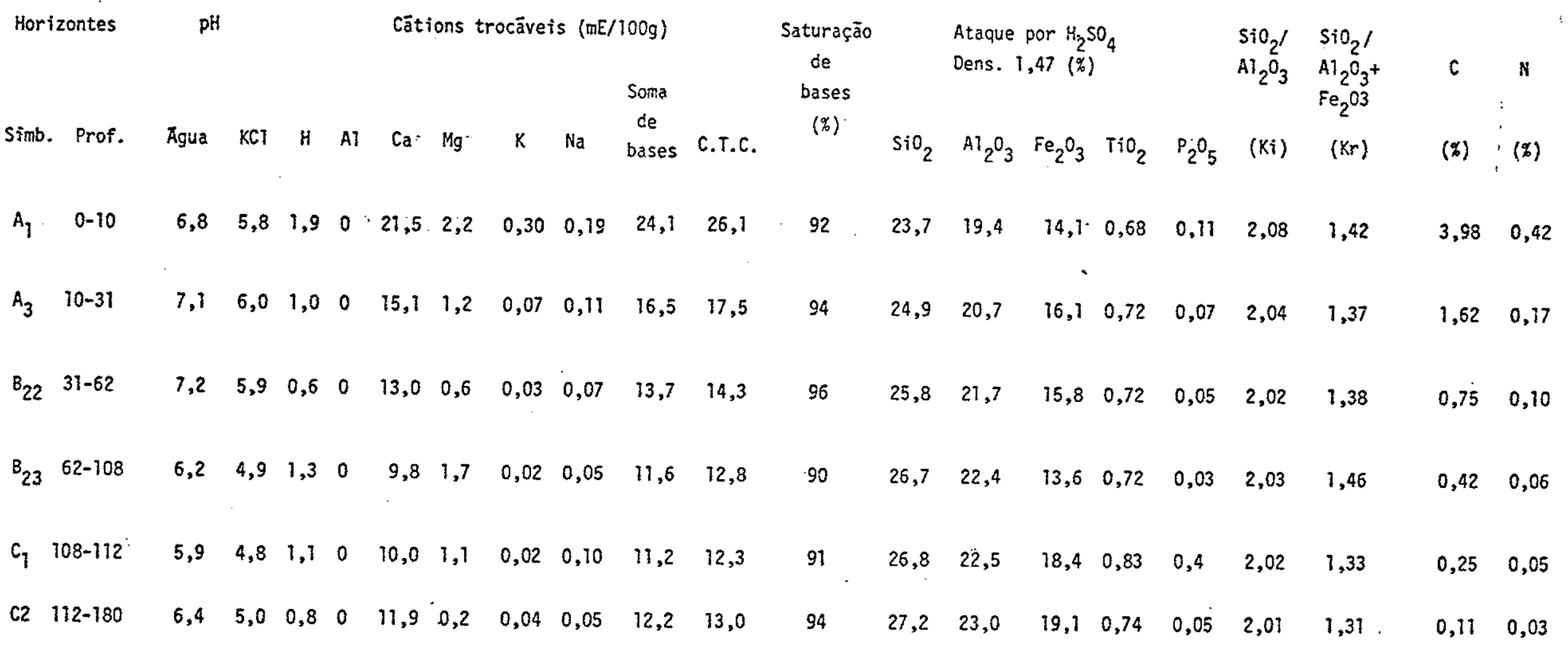


us solos Litōlicos eutröficos distribuem-se em äreas :ocalizadas, onde a intensidade erosiva fez aflo rar a rocha calcäria. São solos pouco desenvolvidos com horizonte A sobre a rocha ou sobre horizonte $C$ de peque na espessura.

C - Solos caracterizados por rocha mãe particular

Estes solos são representados pelas Arejas Quartzo sas distróficas.

As Areias Quartzosas distrōficas (AQd) são solos areno-quartzosos profundos, pouco desenvolvidos, com ho rizontes $A$ e $C$ contendo baixos teores de argila (menos de $15 \%)$. A diferenciação entre os horizontes $A$ e $C \bar{e}$ di fícil, face à pequena variação na coloração e textura.

Estes solos distribuem-se em grande parte dos ter raços intermediärios e superior, derivados de depósitos aluvionares arenosos.

As TABELAS 12 e 13 apresentam as caracteristi cas fisicas e quimicas desses solos. Conforme pode ser observado, as características que mais se destacam nes ses solos são:

- são solos profundos, com mais de 2,00 metros, extrema mente arenosos, com progressivo aumento em argila e si] te em profundidade. 
TABELA 12 - Caracteristicas físicas principais das Areias Quartzosas diströficas (AQd) obtidas segundo EMBRAPA/EPAMIG/RURALMINAS, 1976

\begin{tabular}{|c|c|c|c|c|c|c|c|c|c|c|c|}
\hline \multicolumn{2}{|c|}{ Horizontes } & \multicolumn{4}{|c|}{$\begin{array}{l}\text { Composição Granulomētrica } \\
(\%)\end{array}$} & \multirow{2}{*}{$\begin{array}{l}\text { Argila } \\
\text { Natural } \\
(\%)\end{array}$} & \multirow{2}{*}{$\begin{array}{l}\text { Grau de } \\
\text { Flocula- } \\
\text { ção }(\%)\end{array}$} & \multirow{2}{*}{$\begin{array}{l}\text { Relação } \\
\text { Silte/ } \\
\text { Argila }\end{array}$} & \multicolumn{2}{|c|}{ Densidade } & \multirow{2}{*}{$\begin{array}{c}\text { Porosidade } \\
(\%)\end{array}$} \\
\hline Simb. & $\begin{array}{l}\text { Prof. } \\
(\mathrm{cm})\end{array}$ & $\begin{array}{l}\text { Areia } \\
\text { Grossa }\end{array}$ & $\begin{array}{c}\text { Areia } \\
\text { Fina }\end{array}$ & Silte & Argila & & & & Apar. & Real & \\
\hline A & $0-14$ & 81 & 10 & 3 & 6 & 1 & 83 & 0,50 & 1,28 & 2,51 & 49 \\
\hline$c_{1}$ & $14-81$ & 81 & 9 & 1 & 9 & 1 & 89 & 0,11 & 1,41 & 2,52 & 44 \\
\hline$c_{21}$ & $81-135$ & 72 & 17 & 0 & 11 & 2 & 82 & - & 1,39 & 2,60 & 46 \\
\hline$c_{22}$ & $135-200$ & 71 & 15 & 1 & 13 & 2 & 85 & 0,08 & 1,51 & 2,62 & 42 \\
\hline
\end{tabular}


TABELA 13 - Características quimicas principais das Areias Quartzosas diströficas (AQd) obtidas segundo EMBRAPA/EPAMIG/RURALMINAS, 1976

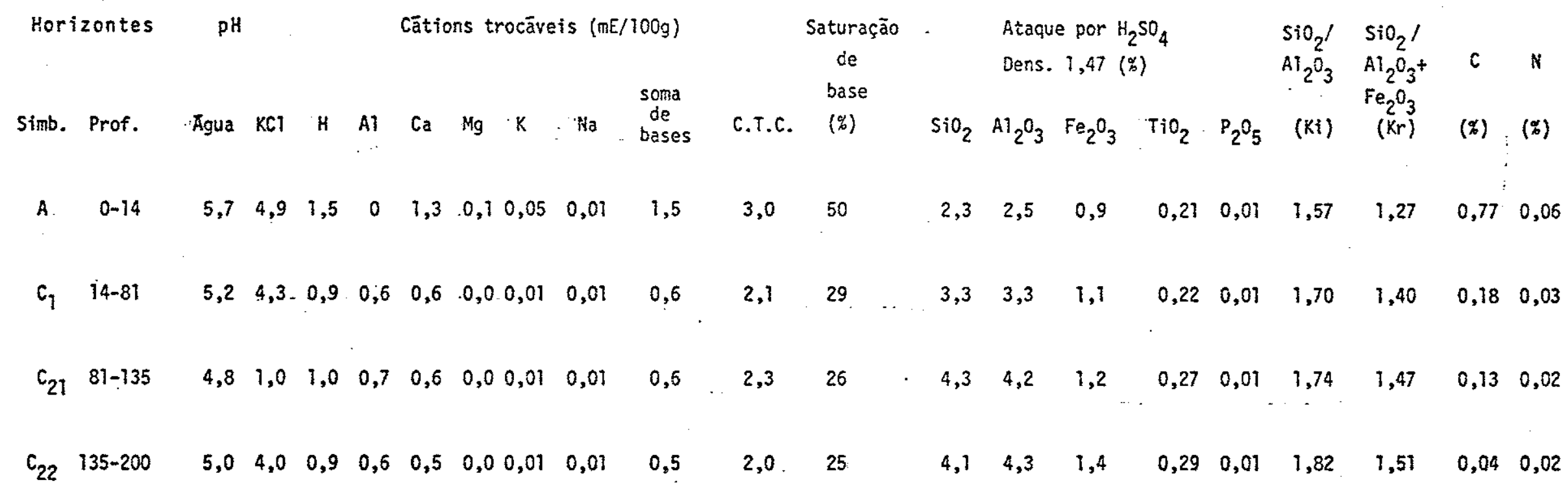


- são excessivamente drenados, dessaturados, muito àcidos e com aumento em profundidade nos teores de $\vec{x}$ idos de silicio, ferro e aluminio.

D - Solos caracterizados por ausência de alteração

São solos pouco desenvolvidos, representados pelos Solos Aluviais eutröficos, desenvolvidos sobre sedimen tos aluviais mais recentes.

Entre os Solos Aluviais eutróficos distinguem-se na região estudada três subclasses: Solos aluviais eu tröficos textura argilosa $\left(A_{1}\right)$, solos Aluviais eutröfi - cos textura argilosa, imperfeitamente drenados $\left(\mathrm{Ae}_{2}\right)$ e Solos Aluviais eutrōficos textura arenosa $\left(\mathrm{Ae}_{4}\right)$. Os dois primeiros encontram-se localizados sobre o terraço inferior, enquanto que os Solos Aluviais eutröficos tex tura arenosa localizam-se no terraço intermediärio.

A principal distinção entre os Solos Aluviais! eu tróficos textura argilosa $\left(\mathrm{Ae}_{1}\right.$ e $\mathrm{Ae}_{2}$ ) se faz pela pre sença de mosqueamento proveniente de gleização. Essa ca racteristica é particularmente observada nos solos alu viais textura argilosa imperfeitamente drenados $\left(\mathrm{Ae}_{2}\right)$, principalmente no horizonte $C$. Estes solos gleizados apresentain-se encharcados em boa parte do ano, tendo em vista o regime de variação do lençol freātico sob in fluência do rio são Francisco. 


\subsection{As Associações Geopedolögicas}

Conforme evidenciado no item anterior existe na re gião estudada uma correspondência marcante entre os vä rios componentes da paisagem: a litologia, o relevo, os solos e a vegetação constituindo as associações geope dolögicas apresentadas na TABELA 14.

A anălise dessa tabela permite a identificação das seguintes associações geopedolögicas:

- Associagão 1: solos Litólicos associados a afloramentos de rocha calcária. ocorre nos morros isolados e nos "lajeados", äreas que testemunham intensa erosão a que foi submetida a região. Nos morros isolados esta as. sociação concentra-se em suas porções mais elevadas.

- Associagão 2: Salos Aluviais eutróficos em substrato sedimentar argizoso. ocorre no terraço inferior, em posição topogräfica sujeita às influēncias hĩdricas e deposicionais do rio São Francisco.

- Associasõ 3: Solos Aluviais eutróficos e Areias Quart zosas distróficas em substrato sedimentar arenoso. ocorre no terraço intermediārio, em posição topogräfica não sujejta à ação direta do rio são Francisco. os so los desta associação são formados exclusivamente a 
TABELA 14 - Associações geopedolōgicas

\begin{tabular}{|c|c|c|c|c|}
\hline $\begin{array}{l}\text { Associações } \\
\text { Geopedologi } \\
\text { cas }\end{array}$ & Litologia & Relevo & $\begin{array}{c}\text { Tipos } \\
\text { Pedologicos }\end{array}$ & $\begin{array}{c}\text { Vegetação } \\
\text { Natural }\end{array}$ \\
\hline 1 & $\begin{array}{l}\text { calcärio } \\
\text { aflorante }\end{array}$ & $\begin{array}{c}\text { Morros } \\
\text { testemunhos }\end{array}$ & $\begin{array}{c}\text { Solns } \\
\text { Litolicos. } \\
\text { (Re) }\end{array}$ & $\begin{array}{c}\text { Caatinca } \\
\text { hiperxerofila }\end{array}$ \\
\hline 2 & $\begin{array}{l}\text { sedimentos } \\
\text { argilosos } \\
\text { aluvionares }\end{array}$ & $\begin{array}{l}\text { Terraço } \\
\text { inferior }\end{array}$ & $\begin{array}{c}\text { Solos } \\
\text { Aluviais } \\
\text { eutroficos } \\
\text { textura } \\
\text { argilosa } \\
\left(\mathrm{Ae}_{1} ; \mathrm{Ae}_{2}\right)\end{array}$ & $\begin{array}{c}\text { floresta } \\
\text { perenifolia }\end{array}$ \\
\hline 3 & $\begin{array}{l}\text { sedimentos } \\
\text { arenosos } \\
\text { aluvionares }\end{array}$ & $\begin{array}{c}\text { Terraço } \\
\text { intermediärio }\end{array}$ & $\begin{array}{l}\text { Solos } \\
\text { Aluviais } \\
\text { eutroficos } \\
\text { textura } \\
\text { arenosa } \\
\left(\mathrm{Ae}_{4}\right) \\
\text { Areias } \\
\text { Quartzosas } \\
\text { distroficas } \\
\text { (AQd) }\end{array}$ & $\begin{array}{c}\text { floresta } \\
\text { subcaducifolia } \\
: \\
\text { Caatinga } \\
\text { hipoxerofila }\end{array}$ \\
\hline 4 & $\begin{array}{l}\text { sedimentos } \\
\text { areno- } \\
\text { argilosos } \\
\text { aluvionares }\end{array}$ & $\begin{array}{l}\text { Terraço } \\
\text { superior }\end{array}$ & $\begin{array}{c}\text { areias } \\
\text { quartzosas } \\
\text { distróficas } \\
\text { (AQd) } \\
\text { Latosol } \\
\text { Vermelho- } \\
\text { Amarelo } \\
\text { distrofico } \\
\text { (LVd) } \\
\text { Cambisol } \\
\text { eutrófico } \\
\text { (Ce } 2 \text { ) }\end{array}$ & $\begin{array}{l}\text { Caatinga } \\
\text { hipoxerófila } \\
\text { floresta/ } \\
\text { caatinga } \\
\\
\text { floresta } \\
\text { caducifolia }\end{array}$ \\
\hline 5 & $\begin{array}{l}\text { sedimentos } \\
\text { argi losos } \\
\text { coluvionares }\end{array}$ & glacis & $\begin{array}{c}\text { Latosol } \\
\text { Vermelho } \\
\text { Escuro } \\
\text { distrofico } \\
\text { (LEd) } \\
\text { Cambisol } \\
\text { eutröfico } \\
\left(\mathrm{Ce}_{3} ; \mathrm{Ce}_{1}\right)\end{array}$ & $\begin{array}{c}\text { floresta } \\
\text { caducifolia }\end{array}$ \\
\hline
\end{tabular}


partir de depósitos sedimentares arenosos contendo acu mulaçöes incipientes de öxido de ferro, observadas prin cipalmente nas porções inferiores do perfil.

- Associąão 4: Latosol Vexmetho Amarelo distrófico, Areias Quartzosas diströficas e Cambisol autrófico em substrato sedimentar areno-argizoso. ocorre no terra co superior, cujo material original, constituĩdo por areias finas e grossas com camadas esparsas de argilas, foi submetido a alteração ferralitica, resultando numa diferenciação do perfil com concentração de sesquiōxi dos de ferro e aluminio, e de argilas cauliniticas.

0 Latosol Vermetho Amarelo diströfico predomina no terraço superior sendo, entre os demais solos da asso. ciação 4, o mais evoluĩdo pedologicamente. São formados a partir de sedimentos aluvionares arenosos da Formação das Vazantes com grande contribuição de elementos prove nientes de rochas carbonäticas da Formação Sete Lagoas.

As Areias Quartzosas distróficas, solos conceitual mente definidos como pouco evoluidos, ocorrem em ampla distribuição no terraço superior. Deve-se entretanto ressaltar que as caracteristicas morfolögicas destes so los diferem profundamente dos encontrados no terraço in termediārio. No terraço intermediārio estes solos apre sentam perfis texturalmente homogeneos, constituidos por areia praticamente pura, onde morfologicamente pode 
ser distinguido um horizonte $A$ superior com aproximada mente $0,20 \mathrm{~m}$ de espessura, e um horizonte $c$ subjacente, muito semelhante ao horizonte superior, tanto na textu ra como na coloração, com espessuras superiores a $2,0 \mathrm{~m}$; no terraço superior as Areias Quartzosas diströficas apresentam geralmente perfis heterogēneos, onde super ficialmente ate $1,0 \mathrm{~m}$ de profundidade, o material $\bar{e}$ es sencialmente arenoso e logo abaixo o material torna-se progressivamente mais argiloso, com espessuras que po dem atingir até cerca de 10 metros.

os Cambissolos eutróficos, distribuem-se no terra ço superior em áreas rebaixadas localizadas. Originam-se a partir de sedimentos aluvionares argilosos (arg la praticamente pura). Em função da sua procedēncia ar gilosa, que da ao material original caracteristicas de baixa permeabilidade, estes solos apresentam menor de senvolvimento, menor profundidade que os demais solos do Terraço superior, e grande porcentagem de consti tuintes originais pouco intemperizados.

- Associagão 5: Latosol Vermetho Escuro distrófico e Cambisol eutrófico em substrato coluvionar argizoso. ocorre entre o terraco superior e o sopé dos morros tes temunhos, correspondendo a uma unidade geomorfolögica definida por "glacis". 
() Latosol Verme Tho Escuro distrófico $\overrightarrow{\mathrm{e}}$ o solo mais evoluicio, dentre os encontrados no depösito coluvionar. Origina-se a partir de sedimentos coluvionares com gran de contribuição de elementos provenientes da alteração de rochas carbonäticas da Formação sete Lagoas.

Os Cambissolos representam solos menos evoluidos do depösito coluvionar, distribuädos em āreas rebaixa das. A menor evolução desses solos deve-se a un certo confinamento da drenagem, o que limitou o mecanismo de lixiviação dos materiais originais, concentrando no per fil minerais primärios pouco intemperizados. Esses mine rais constituem a fração silte desses solos, dando em consequencia, uma relação silte/argila relativamente al ta. Devido tambēm à posição em que esses solos ocupam" (āreas rebaixadas), ocorre continua deposição superficial de sedimentos coluvionares, contribuindo para uma certa heterogeneidade textural.

\subsection{A Interpretação Geopedolögica}

As condições climāticas da região estudada, (Tropi cal de Savana), com alternäncia bem marcada entre perí do chuvoso e seco, apresenta tendéncia favorävel ao de senvolvimento de uma hidrölise parcial devendo resultar numa alteração intermediāria entre a alteração ferral tica e a alteração fersialitica. Na alteração ferralit i ca predomina a hidrölise total dos minerais do substra to rochoso caracterizada por uma liberação completa da 
sîlica e bases com acumulação no perfil de hidröxidos de ferro e aluminio; por outro 1 ado, a alteração fersia Iitica caracteriza-se por um mecanismo de hidrölise on de a liberação da sîlica e dos alcalino-terrosos $\bar{e}$ in completa, favorecendo a neoformação de argila do grupo $2: 1$.

Entretanto, as condições teoricamente esperadas em termos da evolução pedológica para a região estudada, não foram totalmente confirmadas. Realmente, observa-se uma predomināncia de solos ferraliticos intensamente li xiviados e portanto com baixa saturação de bases e ba xa capacidade de troca cationnica.

Nestas condições, outros fatores pedogenēticos, mais diretamente relacionados à situação local do méio deverão ser analisados em conjunto com o clima regio nal. Assim, o substrato pedogenētico quando constituĩdo por sedimentos aluvionares arenosos e coluvionares, apre sentam drenagem interna elevada, favorecendo uma ace leração na evolução do perfil. Deve-se tambëm conside rar, prinicipalmente para as formações aluvionares, o fa tor tempo, como um elemento importante na definição do estágio evolutivo do solo.

Tendo em vista os aspectos citados, a interpreta ção geopedolögica da região estudada, deve necessāria mente ser analisada distinguindo-se as värias situaçöes do meio físico, anteriormente definidas sob a denomina ção de Associações Geopedolögicas. 
De uma maneira geral dois grandes ambientes geope dolögicos destacam-se na paisagem: o primeiro represen tado pela formação coluvionar distribuída ao longo do "glacis" e o segundo representado pelas formações alu vionares distribuidas nos diferentes nîveis de terraços.

Nesses ambientes, a ferralitização $\vec{e}$ o fenōmeno principal na diferenciação pedogenëtica, estando condi cionado à ação conjugada de certas particularidades do meio onde se destacam:

- a drenagem do substrato pedogenētico, favorecen do a percolação d'ägua;

- os materiais originais sobre os quais os solos se desenvolvem, seu estado de alteração, e em particu lar suas caracteristicas mineralógicas, tais como a existência de minerais ricos em ferro e aluminio;

- as características geomorfolögicas, isto $\bar{e}, 0$ ti po de modelado e a posição dos solos sobre esse; model a do;

- as ações biológicas, principalmente aquelas pro vocadas por termitas, vermes, formigas e microorganismo.

3.4.1 Ambiente Geopedolögico I: solos desenvolvidos so bre sedimentos coluvionares

Caracteriza-se por uma pedogēnese desenvolvida so bre substrato coluvionar argiloso, cuja origem está re 
lacionada à desagregação fĩsico-química das rochas da Formação Sete Lagoas e sedimentação com transporte por gravidade. Esse material (colüvio), altamente argiloso, apresenta entretanto alta permeabilidade, e sua espes sura aumenta gradativamente à medida que se afasta dos afloramentos rochosos.

os tipos pedolögicos representativos desse ambien te são os Latossolos Vermelho Escuro diströficos e os Cambissolos eutröficos, cujas caracteristicas físicas e químicas principais foram anteriormente apresenta das (item 3.2.5).

Entre esses solos, os cambissolos apresentam carac teristicas que permitem enquadră-los num estāgio evolu tivo intermediārio entre a alteração fersilittica e fer ralitica.

Entre essas características comuns a esse estägio evolutivo ressaltam-se as seguintes:

a) ocorrēncia do fenômeno de migração de argịla, identi ficado pela presença de cerosidade nos horizontes in feriores, e aumento progressivo em profundidade nos teores de argila;

b) capacidade de troca catioñica da fração argìla, rela tivamente elevada;

c) relação sîlica/alumina $(\mathrm{Ki})>2,0$;

d) hidrōlise neutra a pouco äcida e incompleta, manten do no solo uma reserva importante de minerais pouco alterados; 
e) colmatação da argila nos horizontes inferiores poden do evidenciar mosqueamento característico de gleiza ção.

Estes solos ocupam posições rebaixadas do relevo, principalmente no fundo de depressões superficiais. Nes sas condições, observa-se um certo confinamento da dre nagem nas partes inferiores do perfil, dado a presença a pequenas profundidades do substrato calcärio. Existe, portanto, uma influência direta no desenvolvimento pedo genético desses solos, tanto do material coluvionar em superficie, como do substrato calcārio em subsuperfície cie. Estas condições, permitem continua concentraçãones ses solos de elementos migrados, resultando em maior sa turação de bases e evolução mais lenta. Estas condições favorecem à formação de argilominerais do grupo 2:1 prin cipalmente nas partes inferiores dos perfis, conforme demonstrado nas TABELAS 15,16 e 17. Essas tabelas apresentam o resultado de anälises mineralögicas por di fratometria de raio-X, em amostras representativas dos diferentes solos encontrados na região.

Com relação aos Latossolos Vermelho Escuro, essas características não se mantēm, sugerindo a predominān cia do fenōmeno de lixiviação acompanhado de pequena mi gração vertical da argila. Nestas condições estes solos se identificam a um estägio mais avançado de evolução pedológica, com características muito próximas de solos ferraliticos. Estes solos distribuem-se em posições 
TABELA 15 - Composição dos Argilominerais nos diferentes tipos pedologicos, por difratometria de Raios-X fração inferior à $2 \mu$

PROCEDENCIA DA AMOSTRA

TIPO PEDOLOGICO

LOCAL DE OCORRENCIA

Solos Aluviais eu

tröficos texturä

argilosa imperfej

tamente drenados

$(\mathrm{Ae})$

Solos Aluviais eu

tróficos textura

média (fundo de

dolina)

Solo Hidromörfico

(fundo de dolina)

Areias Quartzosas

distroficas (AQd)

Latosol Vermelho Amarelo textura média (LVd)

Latosol Vermelho Amarelo textura média (LVd)

Cambisol eatrófi co fase substra= to sedimentos ar gilosos. ( $\left.\mathrm{Ce}_{2}\right)$

Terraco inferior

Terraço interme diario

interme

Terraço intermēdiā riolfundo de doli= na)

Terraço intermediario

Terraço superior

Terraço superior

Terraço superior (depressão superfi cial)

\section{LEGENDA}

$+t+t+>80 \%$

$+++t \quad 80 \%$ a $60 \%$

$+++\quad 60 \%$ a $40 \%$

$+\quad 40 \%$ a $20 \%$
$+<20 \%$

tr traços

ilita (m)

TIPOS DE ARGILOMINERAIS

$K$ I V E I E

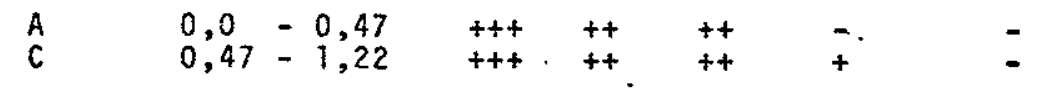

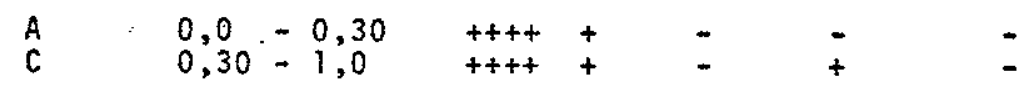

A $0,0-0,60++++++\quad-$

$\begin{array}{llllll}c & 0,38-2,30 & +++++ & t r & t r & -\end{array}$

B $\quad 0,50-2,40++++t$ tr tr $\quad$ tr

$\begin{aligned} & B \\ & B\end{aligned} \quad 5,0=5,80+++++\operatorname{tr}$ tr $\quad$ tr $=$

C $\quad 6,70=7,90$ t+++t tr tr tr $\quad$ tr

$\begin{array}{llllll}B & 0,20-1,20 & +++++ & \text { tr } & \text { tr } & -\end{array}$

$\begin{array}{llll}\text { B } & 0,15-0,50+7+++ & + & +\end{array}$

$v$ vermiculita

$E$ esmectita

I-E camada nista ilita - esmectita 

TABELA 16 - Composição dos Argilominerais nos diferentes tipos pedológicos, por difratometria de Raios=x
fração inferior a $2 \mu$

\section{TIPO PEDOLOGICO}

Cambisol entröfico fase substrato

calcărio ( $\mathrm{C}$ e 1$)$

Cambisol entrofico fase substrato calcario (transição para Latosol vermelho escuro)

Latosol vermelho escuro ditröfico (LEd)

Cambisol entröfico A cheinozēnico $\left(\mathrm{Ce}_{3}\right)$

Cambisol entröfico A cheinozénico ( $\left.\mathrm{Ce}_{3}\right)$ transição

para Latosol vermelho amarelo ditrófico

\section{LEGENDA}

\begin{tabular}{lll}
+++++ & \multicolumn{1}{c}{$>80 \%$} \\
$t+++$ & $80 \%$ a & $60 \%$ \\
$t++$ & $60 \%$ a & $40 \%$ \\
$t+$ & $40 \%$ a & $20 \%$
\end{tabular}

PROCEDENCIA DA AMOSTRA LOCAL DE OCORRENCIA HORIZONTE PROFUNOIDADE

\section{Depositos coluvio} nares (depressãosuperficial)

\section{Depósitos coluvio} nares

Depósitos coluvio nares

Depósitos coluvio nares

Depósitos coluvio nares

\begin{tabular}{|c|c|c|c|}
\hline & $\begin{array}{l}0,20 \\
0,50\end{array}$ & & $\begin{array}{l}0,50 \\
0,7\end{array}$ \\
\hline & $\begin{array}{l}0,15 \\
0,53 \\
1,65\end{array}$ & & $\begin{array}{l}0,5 \\
1,6 \\
1,8\end{array}$ \\
\hline & 0,30 & & 1,0 \\
\hline & $\begin{array}{l}0,30 \\
1,00 \\
2,05\end{array}$ & & \\
\hline & $\begin{array}{l}0,0 \\
0,50 \\
0,87 \\
1,40\end{array}$ & & 1,8 \\
\hline
\end{tabular}

TIPOS DE ARGILOMINERAIS

\begin{tabular}{|c|c|c|c|c|}
\hline $\mathrm{K}$ & I & $v$ & $\mathrm{E}$ & $I=V$ \\
\hline++++ & + & - & - & ++ \\
\hline+++ & + & - & - & +++ \\
\hline+++ & $++t$ & - & - & + \\
\hline+++ & ++ & - & - & + \\
\hline \multirow[t]{2}{*}{+++} & ++ & - & - & + \\
\hline & $\because$ & & & \\
\hline$++t+$ & $+t$ & - & - & - \\
\hline$+++t$ & + & - & - & + \\
\hline+++ & + & - & - & ++ \\
\hline$+++t$ & + & - & $\cdots$ & + \\
\hline+++4 & - & - & - & + \\
\hline+++4 & - & - & - & + \\
\hline++++ & - & - & - & + \\
\hline$+++t$ & $\div$ & - & - & + \\
\hline
\end{tabular}



TABELA 17 - Composição dos Argilominerais nos diferentes tipos pedologicos, por difratometria de Raios-X
fração inferior a $2 \mu$

\section{PROCEDENCIA DA AMOSTRA}

TIPO PEDOLŎGICO

LOCAL DE OCORRENCIA HORIZONTE PROFUNDIDADE

(m).

Latosol Vermelho Amarelo distrófi co $\left(\mathrm{LVd}_{2}\right)$

Cambisol eutrōfi co substrato caT cário (Cel) (trañ sição para latosol vermelho es curo)

Areias Quartzosas distróficas (AQd)

\section{LEGENDA}

\begin{tabular}{|c|c|c|c|}
\hline+++++ & $>$ & & $\%$ \\
\hline$t+t+$ & $80 \%$ & & $60 \%$ \\
\hline$t+t$ & $60 \%$ & a & $40 \%$ \\
\hline$+\div$ & $40 \%$ & $a$ & $20 \%$ \\
\hline
\end{tabular}

Terraço superior

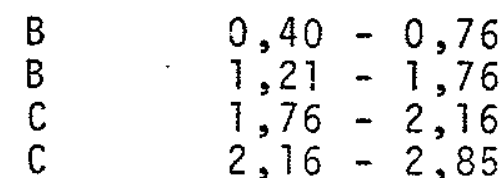

Depösitos coluvio nares

$\begin{array}{ll}\text { B } & 0,05-0,40 \\ \text { B } & 0,70-1,00\end{array}$

$\begin{array}{ll}C & 0,30-0,60 \\ C & 0,60-2,20 \\ C & 2,20-5,20 \\ C & 5,30-7,30\end{array}$

Terraço superior

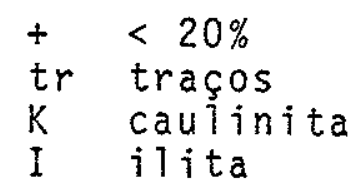

TIPOS DE ARGILOMINERAIS

$\begin{array}{lllll}K & I & V & E & I-E\end{array}$

$\begin{array}{lllll}+++++ & - & - & - & \operatorname{tr} \\ +++++ & - & - & - & \operatorname{tr} \\ +++++ & - & - & - & \operatorname{tr} \\ +++++ & - & - & - & \operatorname{tr}\end{array}$

$\begin{array}{lllll}+++ & +++ & - & - & - \\ +++ & +++ & - & - & -\end{array}$

$++++4+\ldots+0-$

$++++4+2 \quad-4+$

$+t+t+t+2$ 
aplainadas do depösito coluvionar permitindo uma evolu ção pedolögica mais acelerada.

A composição textural e mineralōgica do depōsito coluvionar, onde se destaca a predomināncia das frações finas com fragmentos centimētricos de calcārio, facili ta substancialmente o desenvolvimento da alteração por hidrōiise. A migração vertical e lateral dos elementos, liberados pela hidrōlise $\bar{e}$ igualmente facilitada tendo em vista a sua topografia plana e alta drenagem. Assim, os elementos solubilizados são intensamente lixiviados permitindo rāpida evolução do perfil. Nestas condições, - argilo-mineral formado é predominantemente do grupo das caulinitas.

\subsubsection{Ambiente Geopedolögico II: solos desenvolvidos sobre sedimentos aluvionares}

Sedimentos aluvionares distribuidos nos três ni veis de terraços, constituem um importante fator de pe dogênese dos solos desenvolvidos nesse ambiente geopedo 10̈gico. Estes sedimentos conforme descritos no item 3.2.3, são constituĩdos por depósitos arenosos e argilosos de origem fluvial.

A evolução pedogenëtica observada neste ambiente $\overline{\mathrm{e}}$ condicionada em grande parte à : natureza mineralōgica, textural e topogrāfica do substrato. Deve-se assim con siderar que tendo em vista as condições sedimentolōgi cas do depósito aluvionar e sua maturidade, cada nivel 
de terraço apresenta certas particularidades importan tes no desenvolvimento pedológico; o primeiro terraço, ou terraço inferior, apresenta predomināncia de sedimen tos argilosos, enquanto que o segundo terraço (interme diärio), e o terceiro terraço (superior), constituem-se basicamente por sedimentos arenosos. Por outro lado, existe uma diferença relativa na idade dos diferentes depösitos; à medida que se afasta do curso atual do rio São Francisco a idade do depösito aluvionar aumenta, de modo que o terraço inferior $\overline{\mathrm{e}}$ de origem praticamente atual, e os terraços intermediārio e superior são se quencialmente mais antigos.

Considerando a distribuição pedolögica dos diferen tes terraços, nota-se uma relação direta entre a idade relativa dos depósitos e o estägio evolutivo pedológico. Assim, nos dois primeiros niveis de terraço (inferior e intermediärio), distribuem-se solos pedologicamente pou co evoluĩdos, representados pelos solos Aluviais e Areias Quartzosas distróficas, enquanto que no terraço superior, observa-se a presença de solos mais desenvol vidos, caracterizados pelos latossolos e cambissolos. Os Solos Aluviais e Areias Quartzosas distrōficas, sendo pouco desenvolvidos, guardam caracteristicas muito prō ximas dos materiais originais; nesses solos, o estägio evolutivo não è suficiente para diferenciação pronuncia da do perfil. Merecem anälise interpretativa mais elabo rada os solos distribuidos no terraço superior, cujas 
caracteristicas físicas e quimicas principais foram apresentadas no item 3.2 .5 .

A anālise dessas características denota as mesmas conclusões fundamentais apresentadas para os latossolos e cambissolos distribuídos no ambiente geopedolögico I. Assim, os Latossolos Verme tho Amarelo distrōficos apresentam caracteristicas de pronunciada ferralitização : altamente dessaturados, baixa capacidade de troca ca tiōnica e ausência de horizonte argilico, apresentando tendēncia favorävel a formação de argilas caulinïticas ao longo de todo o perfil. Por outro lado, os cambisso . Ios possuem elevada saturação em bases, presença de ho rizonte $B$ argîlico e tendéncia favorävel a ocorrēncia de argilo-minerais do grupo $2: 1$ nos horizontes inferiores (TABELAS 15,16 e 17).

As caracteristicas morfológicas observadas ao lon go dos perfis ferralitizados do depósito aluvionar suge rem que o processo de ferralitização tenha se desenvol vido apōs deposição dos sedimentos. Esse aspecto, de fundamental importāncia na interpretação pedogenētica desse ambiente, foi constatado atravës de sondagem pro funda atravessando o pacote sedimentar atē o substrato rochoso.

A anälise desses perfis evidencia niveis diferen tes em termos de concentração em ferro e argila, de ma neira que, em condições ideais, pode ser caracterizada a ocorrência de três nîveis: 
- nĩvel superior, homogêneo em termos principalmente de textura e coloração, correspondendo ao horizonte $B$ p. dolōgico; este nîvel, resulta da redistribuição mäxima do ferro e argila homogeneizando o perfil; os valores de $\mathrm{pH}$ evidenciam predomināncia de pedogênese àcida. A concentração de argila e ferro é feita quase que exclu sivamente por acumulação absoluta, cujo mecanismo se de senvolve atravēs de transporte lateral em soluções e atravēs de tranporte vertical pela subida do lençol freā tico e capilaridade. A introdução do ferro e da argila entre os grãos de quartzo resulta num tipo de estrutura ção característica conhecida como "pseudo-areia". Esse fenōmeno foi confirmado atravēs de inspeção em microscō pia eletrónico de varredura, conforme trabalho apresen tado por Wolle e outros (1978);

- nĩvel intermediārio, heterogēneo em termos texturais e de coloração, correspondendo ao horizonte $C$ pedológ co. Este nĩvel apresenta alta concentração de argila e ferro transmitindo uma predomināncia de coloração verme Tha com manchas claras, cuja intensidade aumenta grada tivamente em profundidade, conforme evidenciado na Fo T0 9. Pode ser caracterizado como um nỉvel de concentra ção de argila e zona de variação do lençol freātico; a contribuição do lençol freätico no transporte e concen tração de argila e ferro reveste-se de grande importān cia, sendo provavelmente o principal responsável pela não homogeneização deste nĩvel; 


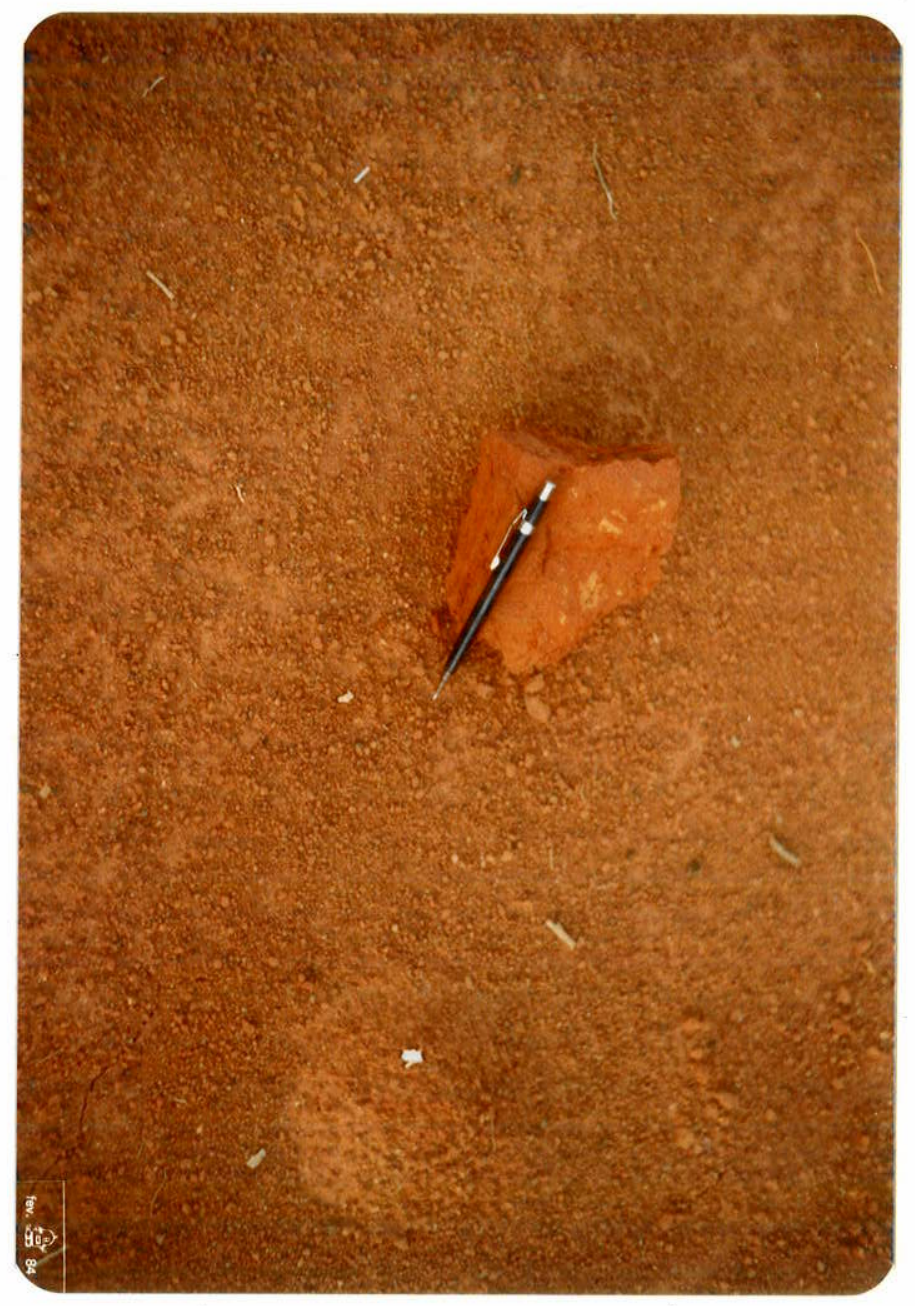

FOTO 9 - Detalhe de uma amostra proveniente do nivel intermediário em perfil de Latosol Vermelho Amarelo distrōfico. 
- nivel inferior, correspondendo à parte inferior do ho rizonte $C$ e horizonte $R$ pedolögico. Este nivel apresen ta apenas em sua porção superior indícios de concentra ção de argila e ferro, transmitindo uma coloração predo minantemente cinza claro.

Tendo em vista a ocorrência, abaixo do depósito aluvio nar de substrato calcārio pertencente à Formação Sete Lagoas, admite-se que esta formação seja a principal res ponsável pelo fornecimento de elementos fundamentais pa ra a ferralitização.

Por outro lado, o comportamento do lençol freātico na região, mostra a possibilidade de uma contribuição importante de elementos migrados provenientes do depósi. to coluvionar. Com efeito, as medidas do nỉvel d'água, realizadas atravēs de sondagens mostram que a percola ção de āgua se dá dos depōsitos coluvionares para os terraços. Esse fato sugere que o processo de alteração, observado no depösito coluvionar e no substrato calcá rio, propiciou a liberação de elementos solūveis, onde se inclui o ferro na forma reduzida, sendo esses elemen tos conduzidos pelo lençol freático para posições de ju sante. A variação vertical do lençol freātico com exces so desses elementos, permite assim a precipitação do ferro nas zonas aeradas do depósito aluvionar.

Una característica comum dos solos ferralitizados existentes no terraço superior. ē a existência de perfis 
com horizonte superficial muito pobre em argila e ferro e que em certas condições pode atingir espessuras de mais de um metro, conforme pode ser notado na FOTO 10.

Esta característica do horizonte superficial levou a definir-se por Areias Quartzosas distróficas, solos distribuídos no terraço superior, cujo aspecto morfolö gico anteriormente descrito, é caracterizado pela pre sença de uma parte superior do perfil com aproximadamen te 1,0 metro de espessura constituida por areia pratica mente pura.

Uma hipōtese que de imediato se levanta, para ex plicar a origem desse horizonte superficial constituĩdo por areia praticamente pura, è que tenham ocorrido par cialmente no terraço superior, fenōmenos de recobrimen to mecānico por erosão, apōs ferralitização do depósito aluvionar. Outra explicação, está relacionada :ao pró prio desenvolvimento pedogenëtico desses solos, onde a migração de certos elementos da parté superior do per fil, pode promover a formação do horizonte superficial arenoso e pobre em argila e sesquiōxidos. Este fenômeno foi constatado por Fauck (1972) em solos ferralitizados da Africa ocidental sobre rochas sedimentares arenosas, onde as condições climāticas são muito prōximas às ob servadas nà região do Jaĩba.

A primeira hipōtese manifesta-se mais evidente, ten do em vista que as āreas de ocorrência das Areias Quart 


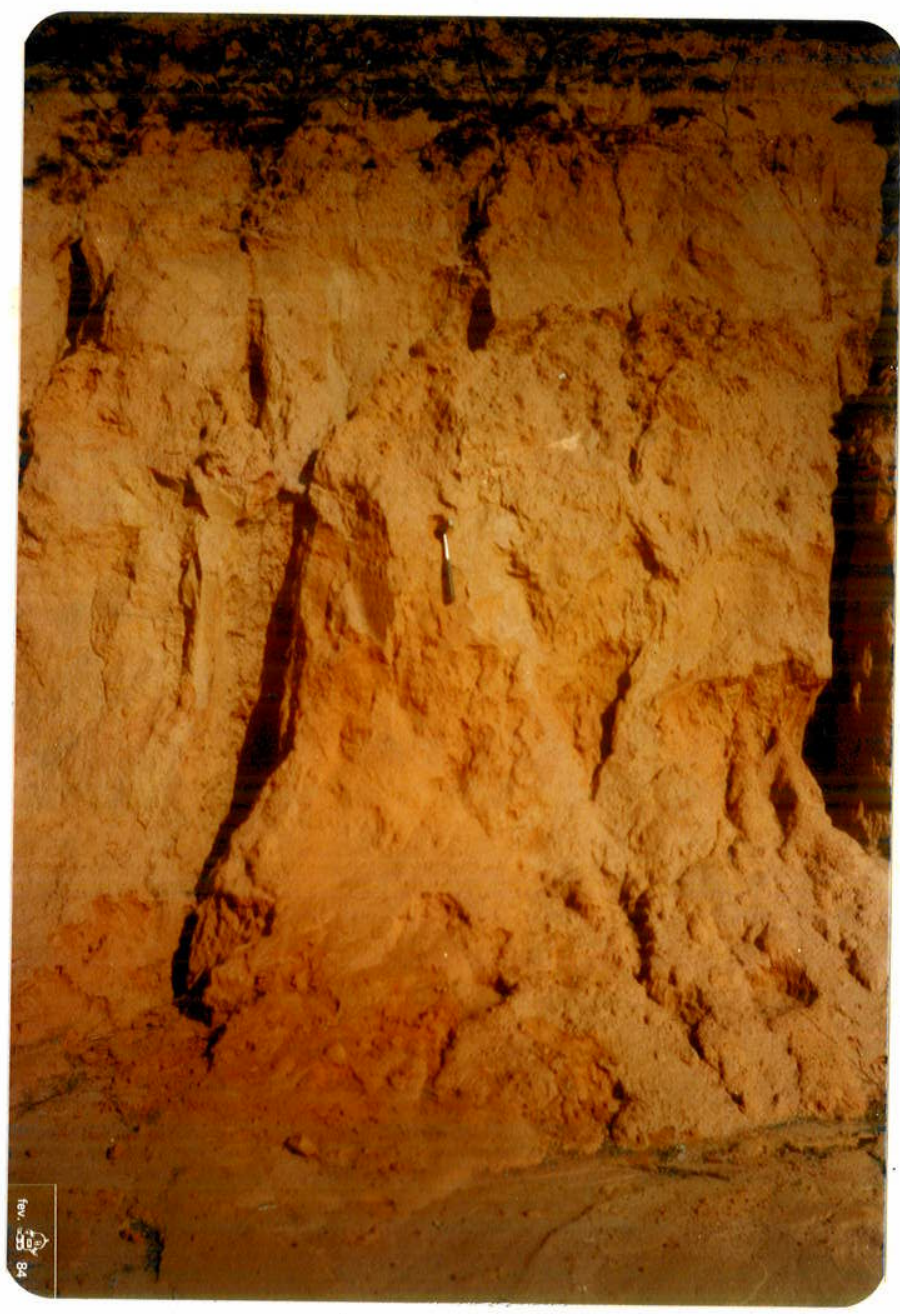

FOTO 10-Corte mostrando o perfil de Areias Quartzosas distróficas (QDd) distribuĩdas no terraço superior. Jazida de solo utiliza do em aterros do canal principal do Projeto Jaība. 


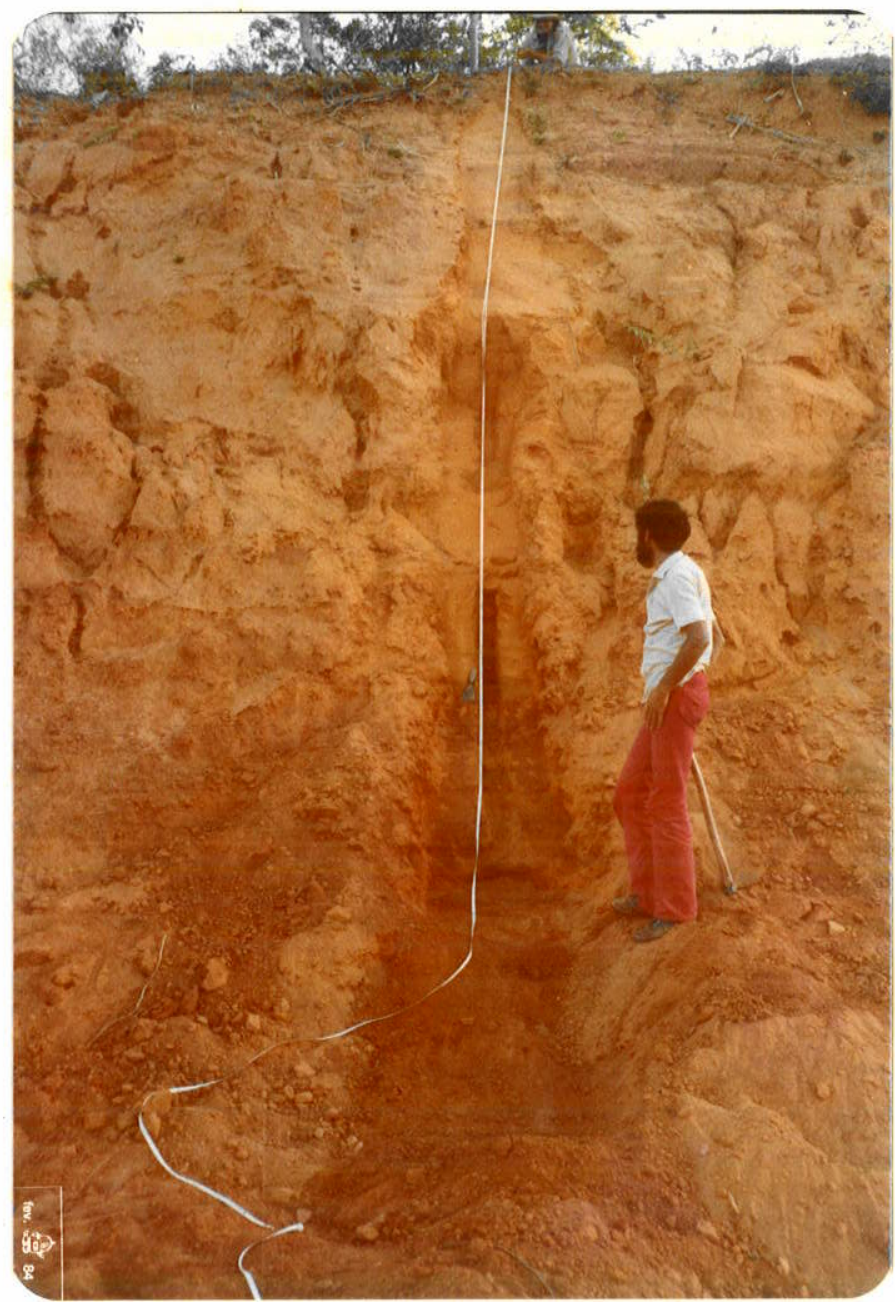

FOT0 11 - Perfil de Areias Quartiosas dis tröficas (AQd) do terraço superior. Notar a mudança de coloração da parte superior do perfil para a parte inferior, devido ao au mento no teor de argila. Jazida de solo utilizado em aterros do Canal principal do Projeto Jaíba. 
zosas diströficas no terraço superior, encontram-se em niveis topogräficos ligeiramente mais baixos, permitin do concluir tratar-se de āreas anteriormente erodidas. 
4 A AFLICAÇAO PARA A GEOLOGIA DE ENGENHARIA - 0 ZONEA MENT? GEOTECNICO

Pedologia e geotecnia têm o solo como elemento comum de estudo. Entretanto, os objetivos, métodos de anālise e conceitos são diferentes, dificultando a cor relação direta entre o mapa pedolögico e as proprieda des geotëcnicas dos solos. Neste sentido, faz-se neces sārio uma interpretação da paisagem que leve em conta o conjunto dos elementos que a constitui, de maneira a en tender os processos pedogenëticos atuantes nos diferen tes solos, a distribuição pedológica e particularidades mineralógicas, físicas e químicas. Estes elementos de anālise, se interpretados para o contexto da geotecnia," fornecem importantes informações orientativas às inves tigações geotécnicas. Os elementos de interpretação geo pedológica devem, neste caso, ser orientados objetivan do a delimitação de zonas geotecnicamente homogêneas, de maneira a servir de referencial para as investiga ções geotëcnicas.

A interpretação geopedológica, conforme realizada para a região do Distrito Agroindustrial do Jaíba (item 3.4), permitiu a reunião de solos geneticamente seme Ihantes sob a denominação de associações geopedolögicas. Cada associação geopedológica reune uma sĩntese do co nhecimento integrado da geologia, geomorfologia e pedo logia, permitindo assim um entendimento pormenorizado 
dosperfis de solo. Dessa forma, as caracteristicas fĩs cas, quimicas, mineralögicas e o correspondente compor tamento mecánico dos solos foram definidos permitindo a delimitação das zonas geotecnicamente homogēneas.

os estudos realizados permitiram a distinção na re gião de oito zonas ou unidades geotëcnicas homogēneas, representadas na FIGURA 6 .

Unidade geotécnica 1: fundo de dolinas e ăreas alagadi cas - As depressões superficiais foram identificadas atravēs de fotointerpretação de fotografias aēreas, es tando representadas no mapa geomorfolögicos (Figura 3 ). Encontram-se dispersas na região, com maior densidade de ocorrēncia nos depōsitos aluvionares da Formação das Vazantes. Estas äreas apresentam drenagem interna defi ciente, condicionando a formação de solos pouco lixivia dos e consequentemente com concentração de bases e sîl ca.

A unidade geotécnica nọ 1 relaciona-se às depres sões superficiais mais profundas observadas na região, em geral superiores a cincometros, e a äreas alagadi ças. A posição topogräfica dessas äreas favorece um aporte considerāvel de material transportado por escor rimento superficial de ägua de chuva. Dessa forma, os solos relacionados à unidade geotēcnica nọ 1 apresentam teores relativamente altos em areias. São solos normal mente saturados em āgua durante praticamente o ano todo 


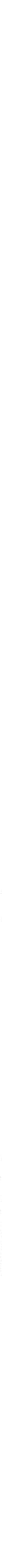


favorecendo a concentração de matëria orgānica, permi tindo em muitos casos o desenvoivimento de solos hidro mörficos. O desenvolvimento pedolögico desses solos, fá vorecem tambēm a formação de argilas do grupo 2:1, cons tatada por ensaios de difratometria de Raios-X : (TABELA 15).

Unidade geotécnica 2: solos pouco desenvolvidos com pre dominio de argiza e sizte - Distribuem-se no terraço in ferior, constituidos por sedimentos aluvionares argilo sos de deposição atual. Correspondem a solos pedologica mente pouco evoluĩdos que mantēm as caracteristicas fi sicas e quimicas do material original.. Foram identifica dos no mapa pedolōgico como Solos Aluviais eutröficos originados a partir de sedimentos argilosos. Apresentam pequena cobertura com aproximadamente $0,20 \mathrm{~m}$ de areja fina praticamente pura, e nas demais posições do perfil predominäncia de finos (argila e silte). 0 desenvolvi mento pedolōgico desses solos condiciona a ocorrēncia ao longo do perfil de significativa quantidade de argi las do tipo $2: 1$.

Unidade geotécnica 3: solos pouco desenvolvidos com pre dominio de areia praticamente pura - Distribuem-se ao longo do terraço intermediārio, e são constituĩdos por sedimentos aluvionares arenosos. Da mesma forma que a unidade anterior, correspondem a solos pedologicamente pouco evoluidos com características físicas e químicas 
semelhantes ao material original. Pedologicamente foram classificados como Solos Aluviais eutröficos e Areias Quartzosas distróficas, originados a partir de sedimen tos arenosos.

Os horizontes inferiores desses solos apresentam-se ligeiramente ferralitizados, transmitindo uma tona lidade avermelhada. Esse processo de ferralitização pro move pequeno enriquecimento em argila caulinitica, não sendo entretanto suficiente para que 10 solo adquira comportamento plästico.

Unidade geotëcnica 4: solos ferralitizados areno-argilo sos com cobertura de areia praticamente pura - ocorrem em grande distribuição no terraço superior, identifica dos como Areais Quartzosas diströficas. O desenvolvimen to pedogenētico destes solos, conforme descrito no item 3.4.2., confere baixa concentração de argila caulin $\bar{i} t \underline{i}$ ca na parte superior do perfil e concentração relativa mente elevada na parte inferior.

Unidade geotëcnica 5: solos ferralitizados areno-argilo sos - Distribuem-se no terraço superior, sendo pedologi camente identificados como Latosol Vermelho Amarelo dis trófico. São solos evoluĩdos, profundos e ferralitiza dos, constituidos basicamente por areia fina e argila caulinitica. O teor em argila aumenta gradativamente em profundidade, não ultrapassando a $50 \%$. 
Unidade geotëcnica 6: solos pouco lixiviados argilo-siz to-arenisos - Ocorrem em äreas rebaixadas observadas tan to no terraço superior como nos depósitos coluvionares. Correspondem aos Cambissolos eutröficos, que, conforme descritos nos itens 3.4 .1 e 3.4 .2 ., apresentam concen tração de argilas do grupo 2:1 principalmente nas par tes inferiores do perfil.

Unidade geotécnica 7: solos ferratilizados argilosos com pouca areia fina - Distribuem-se en āreas de ocorrēncia de sedimentos coluvionares, sendo pedologicamente clas sificados como Latosol Vermelho Escuro diströfico. São solos evoluídos, ferralitizados, constituidos basicamen te por argila caulinitica e ilitica com pequena porcen tagem de areia fina e silte.

Unidade geotécnica 8: afloramento de rochas e solos ra sos - São āreas localizạdas, intensamente erodidas, re lacionadas a ocorrência de morros isolados e lajedos.

As Tabelas nọs 18 e 19 mostram os resultados de en saios granulométricos, mineralógicos e mecānicos em amostras representativas das unidades geotēcnicas homo gêneas. A interpretação desses resultados, conforme re sumo apresentado na Tabela nọ 20, evidencia algumas ca racteristicas e comportamentos geotëcnicos diferentes para cada unidade geotēcnica homogênea, confirmando a validade do método utilizado. A anālise dos resultados 
TABELA 18 - Caracterīsticas texturais, mïneralögicas e mecänicas das unidades geotēcnicas homogēneas

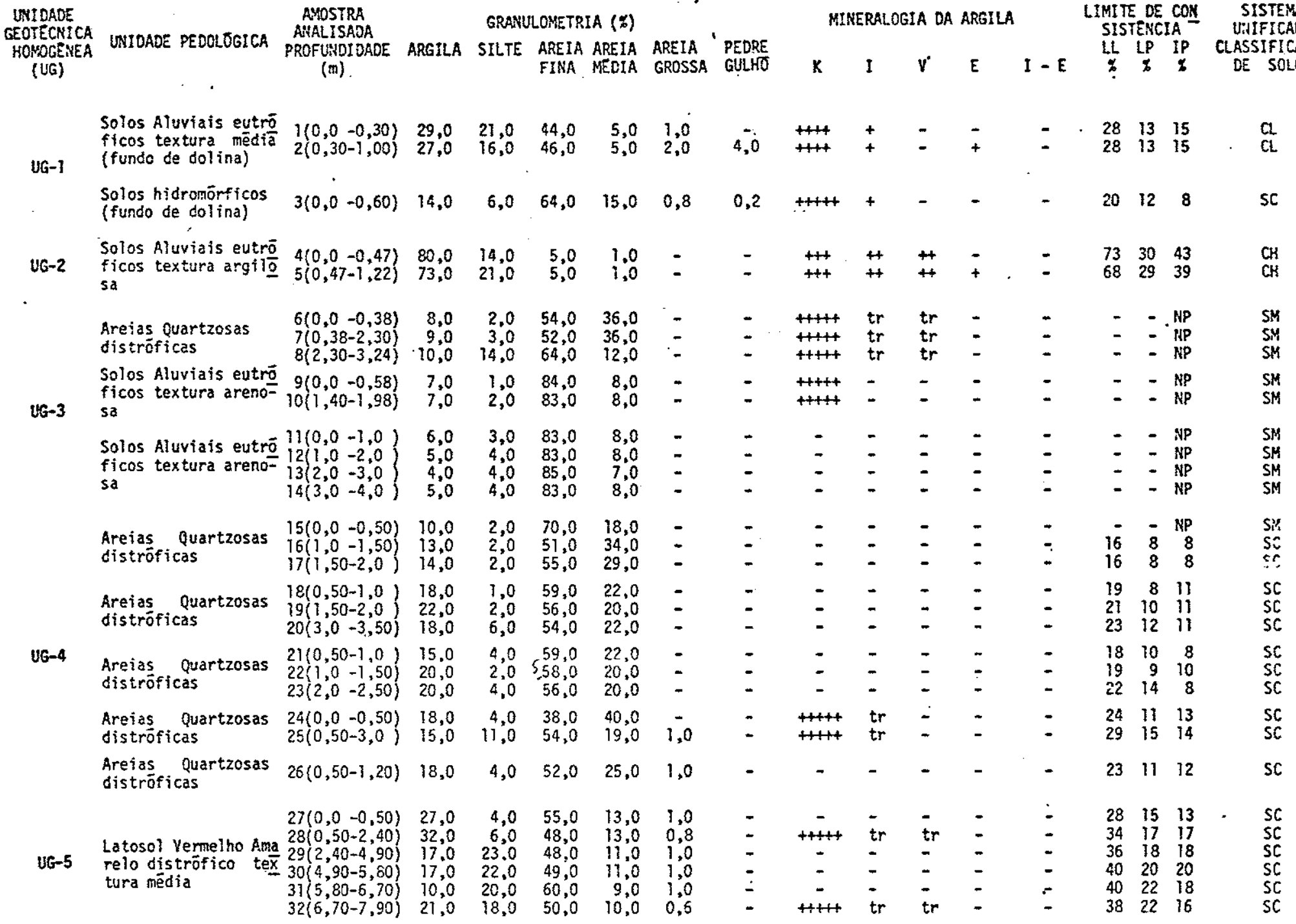

\section{LEGENDA}

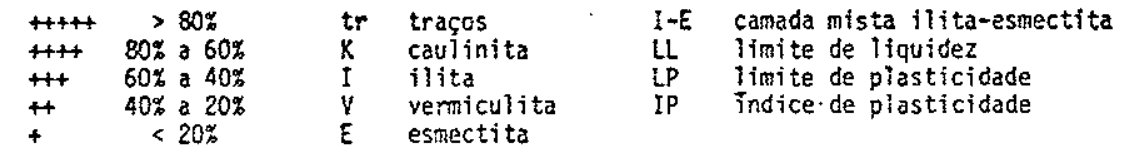




\section{TABELA 19 - Caracteristicas texturais, mineralógicas e mecânicas das unidades geotécnicas homogēneas}

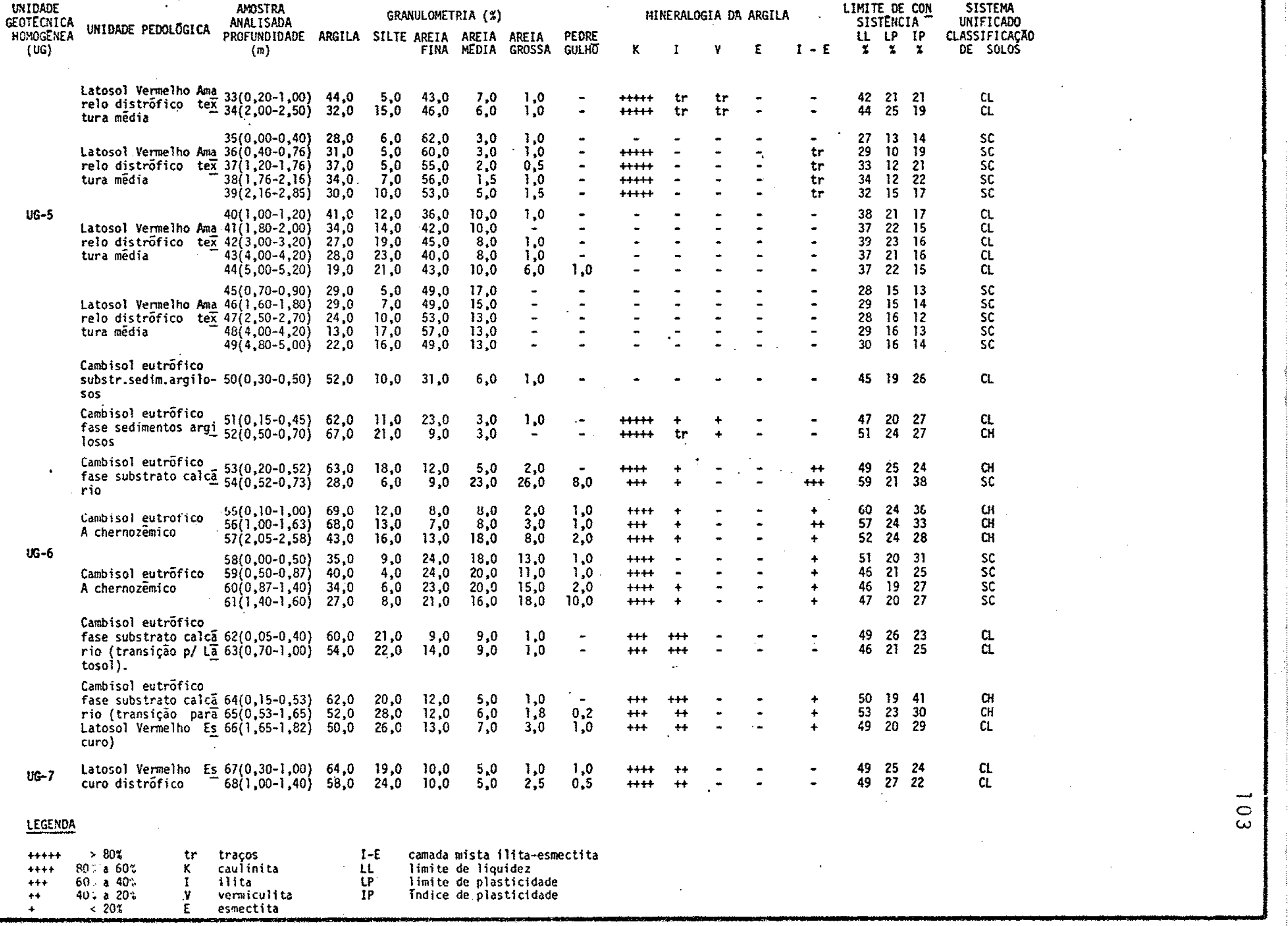


TABELA 20 - Garacterïsticas geotēenicas e previsão de comportamento das unidades geotēcnicas homogēneas.

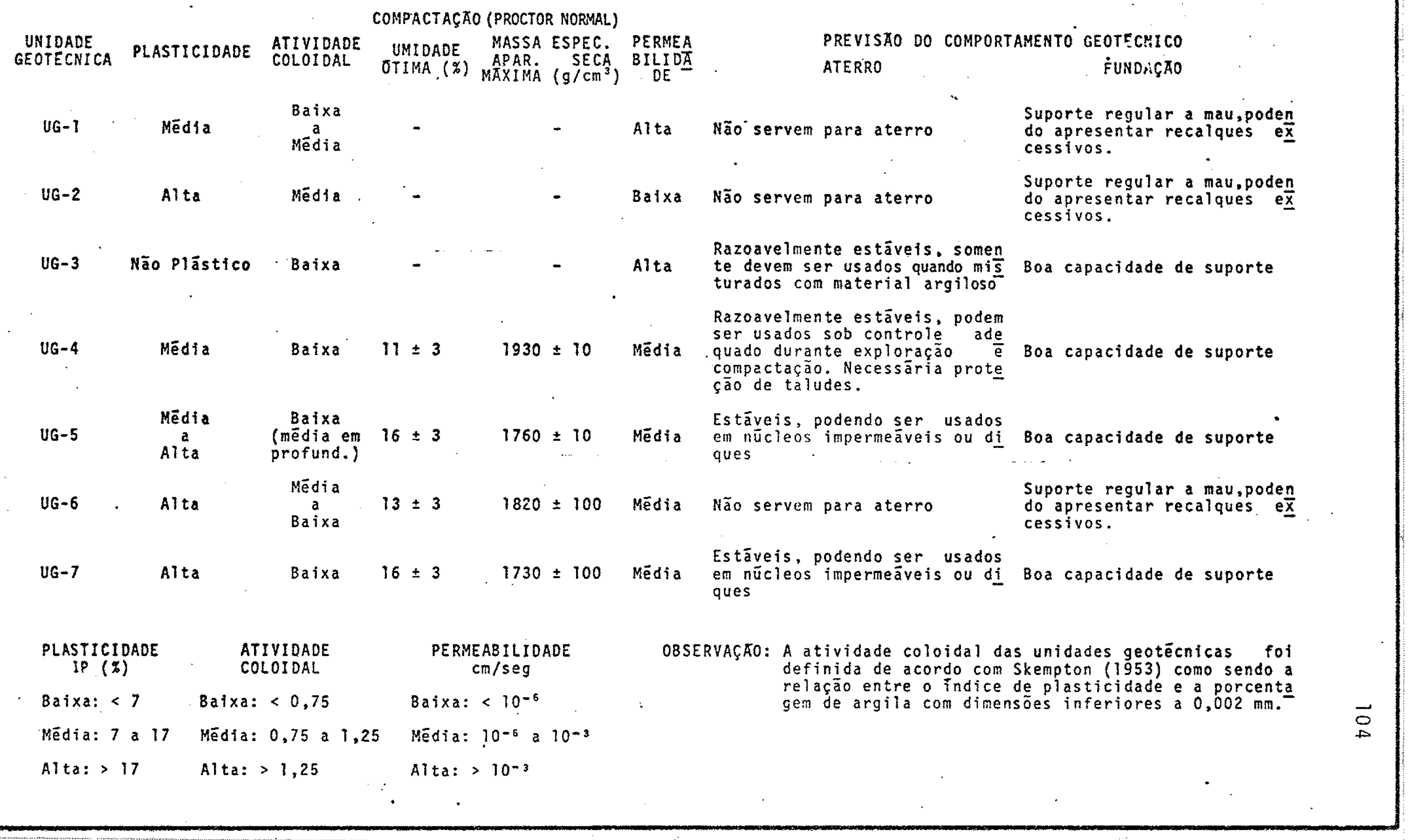


obtidos conduziram às seguintes considerações princị pais:

19) Conforme pode ser verificado nas TABELAS 18 e 19, nem. sempre observa-se uma correlação direta en tre tipos pedolōgicos e unidades geotécnicas homogê neas. 0s estudos realizados mostraram duas situa ções diferentes:

a) Uma unidade pedolōgica correspondente a vārias unidades geotēcnicas. Trata-se dos solos pouco evolui dos (Solos Aluviais eutrōficos e Areais Quartzosas dis trōficas), cujas características texturais e mineralōgi cas mantëm intima relação com o material subjacente do perfil, com variaçöes importantes dependendo da profun didade. Assim, os Solos Aluviais eutróficos associados a sedimentos aluvionares argilosos correspondem à unida de geotécnica nọ 2, enquanto que aqueles associados a sedimentos aluvionares arenosos correspondem à unidade geotécnica no 3. Por outro lado, as, Areias quartzosas diströficas relacionam-se às unidades geotëcnicas 3 e 4, tendo em vista a variação nos teores de argila e silte observado em profundidade.

b) Uma unidade pedolōgica correspondendo univoca mente a uma unidade geotēcnica. Esta situação refere-se aos Cambissolos eutröficos, Ao Latosol Vermelho Amare 10 diströfico e ao Latosol Vermelho Escuro distrōfico. 
Estas unidades pedolögicas correspondem respectivamente às unidades geotēcnicas 5,6 e 7 .

os Cambissolos apresentam-se na regiäo estudada co mo solos argilosos com teor relativamente alto em argi la expansiva, que aumentam em profundidade.

Os Latosolos Vermelho Amarelo e Vermelho Escuro são solos ferralitizados apresentando alto grau de lixi viação. São portanto solos bastante similares quando a gēnese reproduzindo em função disso uma certa semelhan ça no comportamento geotēcnico. Entretanto, apresentam diferenças marcantes quanto ao material de origem condu zindo esses solos a apresentarem texturas diferentes e conseqlentemente algumas caracterīsticas geotécnica es pecificas.

20) A presença de argilas expansivas do tipo vermiculi ta e esmectita, mesmo em pequenas quantidades inter ferem substancialmente no comportamento geotécnico.

Os estudos realizados identificaram presença de ar gilas expansivas nas unidades geotécnicas 2 e 6 , ambas consideradas imprōprias para utilização como aterro com pactados e apresentando baixa capacidade de suporte ( $\underline{i}$ de tABELA 20).

A FIGURA 7 mostra que em geral nota-se um nîtido aumento no indice de plasticidade a medida em que se au menta a porcentagem de elementos finos (argila e silte). Entretanto, as amostras provenientes das unidades geo 


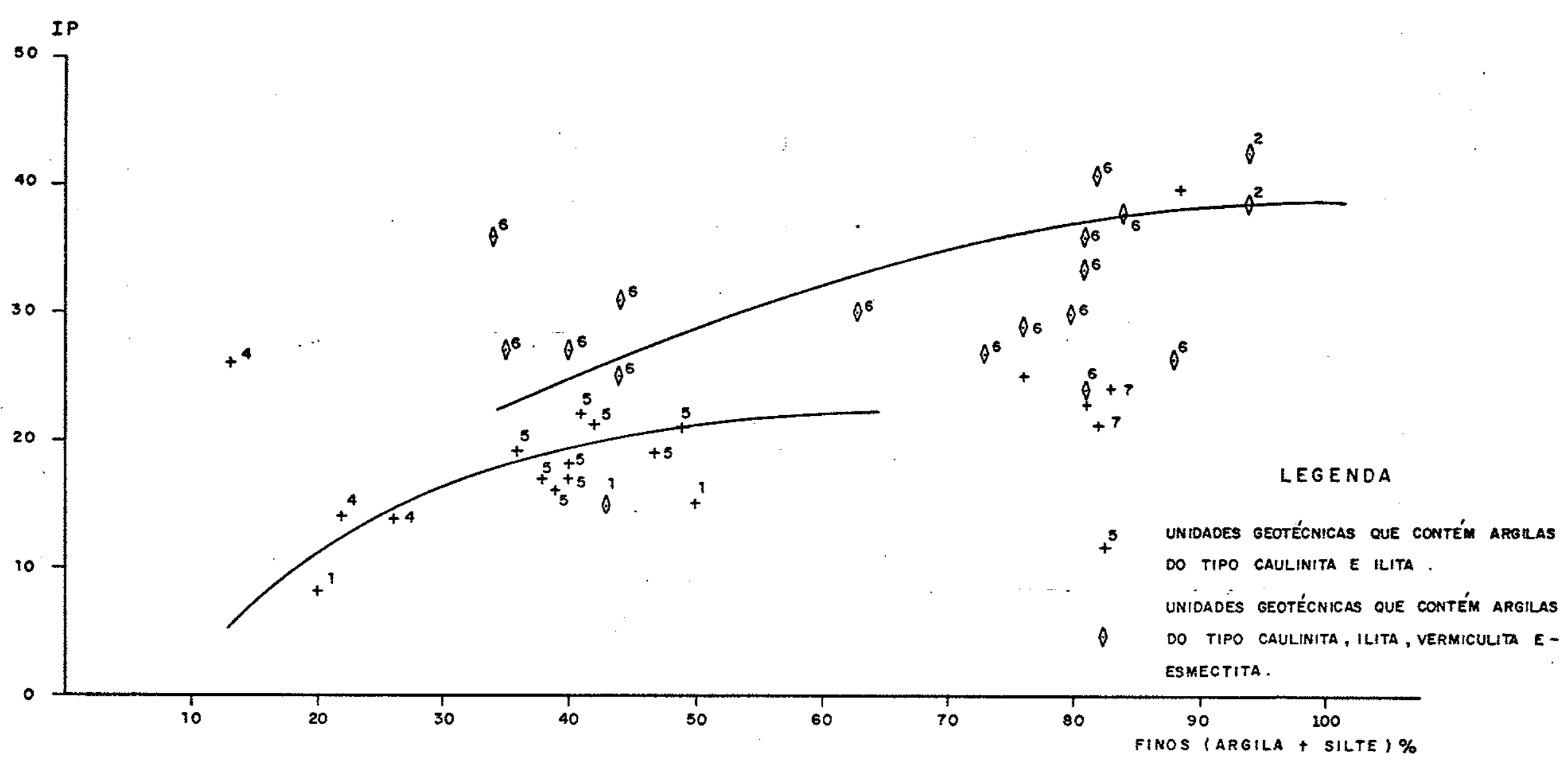

OBS:-TRATA-SE SIMPLESMENTE DE UM GRÁFICO DE VISUALIZAÇĀO SEM INTERPRETAÇÃO ESTATISTICA. FIg. 7 - VARIACOOES DO ÍNDICE DE PLATICIDADE EM FUNC̄ÃO DO TEOR DO SOLO EM ELEMENTOS FINOS -
E DA NATUREZA DAS. ARGILAS. 
têcnicas 2 e 6 revelam valores úe plasticidade bem mais elevados, constatando duas tendêricias na relação entre - indice de plasticidade e porcentagem de finos: uma, representada pela curva situada na parte inferior da FI GURA 7, reune unidades geotēcnicas contendo solos com argilas do tipo caulinita e ilita; a outra tendéncia, representada pela curva situada na parte superior da Fi gura 7 , reune as unidades geotécnicas 2 e 6 cujos solos apresentam argilas do tipo caulinita, ilita, vermiculi ta e esmectita.

30) Na ültima coluna das Tabelas 18 e 19 é apresentada a classificação de solos segundo o Sistema Unifica do de Casagrande. Esse mëtodo, tradicionalmente uti lizado em estudos geotēcnicos identifica os solos com base em suas caracteristicas de textura e plas ticidade.

Conforme pode ser observado, existe uma certa cor respondência entre as unidades geotécnicas homogêneas e determinadas classes de solos. Entretanto, uma mesma classe de solos definida pero Sistema Unificado pode corresponder a unidades geotēcnicas diferentes, como pode ser observado por exemplo com as unidades geotécni cas 5 e 6 . Nessas duas unidades predominam solos clas sificados como SC e CL, apesar de terem comportamentos geotēcnicos completamente diferentes, conforme demons trado na Tabela no 20 . 
Essa contradição da classificação de solos pelo Sistema Unificado, observada na região estudada, vem a confirmar trabalhos apresentados por Nogami (1980), con firmando a importante contribuição da interpretação geo pedolögica na definição das características geotēcnicas. 49) 0 mëtodo de interpretação geotëcnica utilizado mos trou-se viāvel em estudos preliminares onde se dis põe de poucos dados de investigação, servindo prin cipalmente para um planejamento mais seguro de estu dos geotēcnicos subsequentes mais detalhados.

Com relação aos ensaios de laboratōrio requeridos, acredita-se serem suficientes as anälises granulomëtrị cas, mineralōgicas e limites de consistēncia. As unida des geotēcnicas devem sempre ser definidas apös a realj zação desses ensaios, evitando-se assim erros grossej ros de interpretação. Portanto, a interpretação geopedo lögica permite em primeira aproximação a reunião de so los geotecnicamente homogêneos, que devem ser confirma dos após anālise dos resultados dos ensaios de laborató rio.

50) As unidades geotëcnicas homogēneas, como pode ser observado, foram definidas tomando por base a inter pretação do meio fĩsico envolvendo as correlaçōes possiveis entre os aspectos geológicos, geomorfolo gicos e pedolōgicos dentro do contexto de evolução da paisagem. Dessa forma, cada unidade geotécnica 
deve apresentar em subsuperfĩcie certas particulari dades prōprias que se manifestam em comportamentos geotêcnicos diferentes.

Neste sentido, as investigações de subsuperficie visando a implantação de obras civis, se realizadas a partir de uma carta geotēcnica bäsica, tornam-se mais eficientes, não só nos seus aspectos qualitativos, como em economia de tempo e de sondagens.

As Figuras 8 e 9 apresentam seções geolōgico-geo tēcnicas representativas dos sedimentos aluvionares e coluvionares, distribuídos ao longo do traçado geométri - co do Canal Principal de adução do Projeto Jaỉba. Essas seções foram elaboradas com base em sondagens mecānicas e poços de investigação e tiveram como principal objeti vo definir o comportamento dos diferentes materiais atra vessados pelo canal no que se refere à resistência à es cavação e comportamento comofundação.

As unidades geotēcnicas homogēneas, preliminarmen te definidas, serviram de referencial para a locação das sondagens e interpretação dos resultados obtidos. Neste sentido, em cada unidade geotēcnica homogênea foi realizada pelo menos uma sondagem a percussão, de manej ra a fornecer dados de resistēncia a penetração dos di ferentes materiais atravessados. Entre as sondagens a percussão, foram realizadas sondagens a trado e poços de investigação, visando maior detalhamento das investi gações, e fornecendo dados geológico-geotécnicos mais 


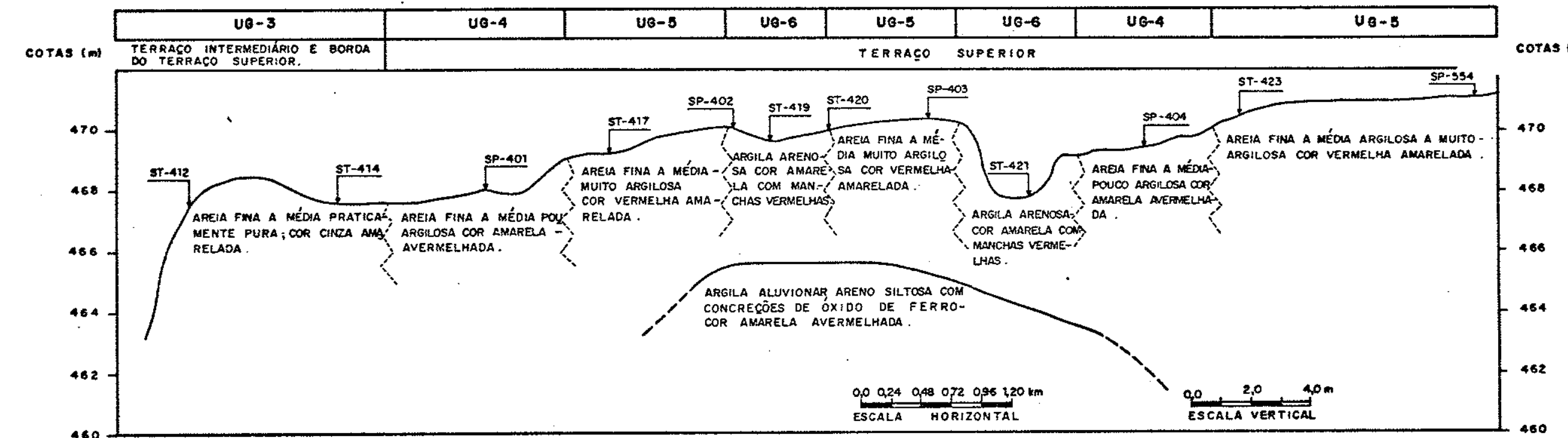

GRANULOMETRIA (VALORES MEDIOS: RESISTENCIA A PENETRACGAO

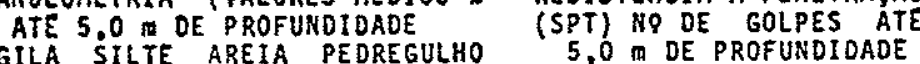

UHIDADE GEOTECNICA ARGILA SILTE AREIA PEDREGULHO

OBSERVAÇOES COMPLEMENTARES

Concreções limoniticas somente observada a grandes profundida des, próximo ao calcärio

Parte superior atē $2,0 \mathrm{~m}$ de pro fundidade constituida por areia praticamente pura cujo teor em argila aumenta em profundidade: observa-se raras concreçoes mi go do perfil

os teores em argila aumentam gradativamente en profundidade presença de raras "concrecoes milimétricas de limonita ao longo do perfil.

Presença de grande guantidade de concreçoes milimetricas centimetricas de limonita, dis tribuidas ao longo do perfil: pode ocorrer niveis de concencas, normalmente próximo ao casi normalmente proxino te.
LEONDA

UQ-- UNIOADE GEOTÉCNICA No 6 


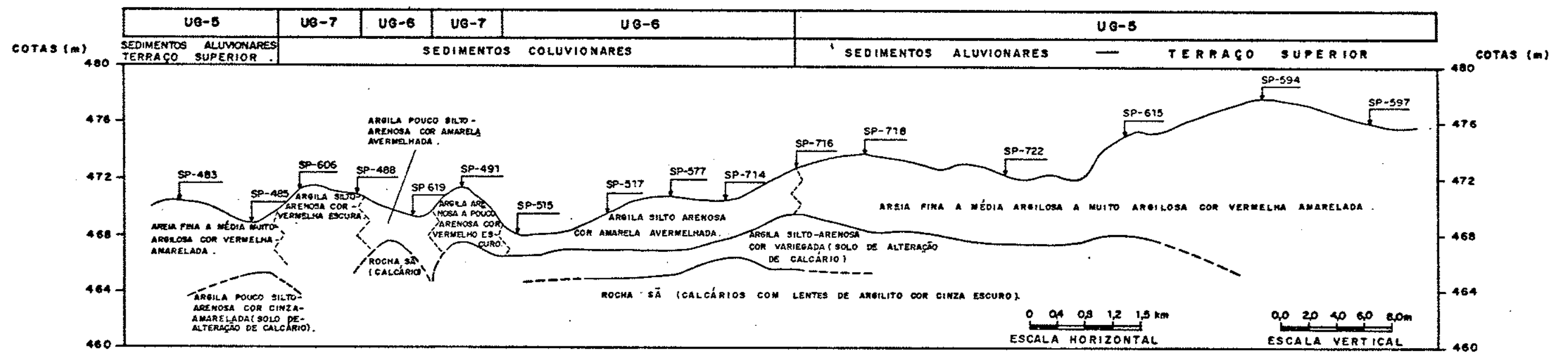

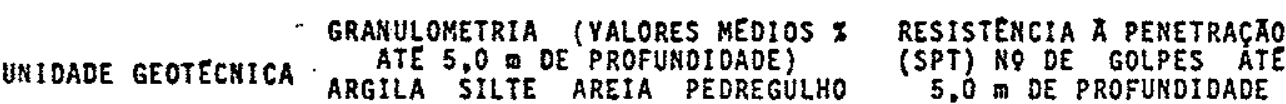

\begin{tabular}{|c|c|c|c|c|c|c|}
\hline UG-5 & 28 & 6 & 66 & - & 5 a 20 & $\begin{array}{l}\text { gradativamente em profundidade } \\
\text { presenca de raras concreçós } \\
\text { milimétricas de limonita ao } \\
\text { longo do perfil }\end{array}$ \\
\hline UG-6 & 60 & 15 & 15 & 10 & 10 a 40 & $\begin{array}{l}\text { Presença de grande quantidade } \\
\text { de concrecoes milimetricas e } \\
\text { centimetricas de limonita, dis } \\
\text { tribuidas ao longo do perfil } \\
\text { pode ocorrer nivejs de concen- } \\
\text { traçao de concreçoes limoniti- } \\
\text { cas, normamente proximo ao } \\
\text { contacto com a rocha subjacen- } \\
\text { te. }\end{array}$ \\
\hline UG-7 & 50 & 20 & 28 & 2 & $10 \times 30$ & $\begin{array}{l}\text { Presença de raras concreçōes } \\
\text { milimétricas de limonita do } \\
\text { longo do perfil }\end{array}$ \\
\hline
\end{tabular}

\section{OBSERVACOES COMPLEMENTARES}

Os teores em argila aumentam gradativamente em profundidade milimétricas de limonita ao ngo do perfil

\section{LE G NOA}

UQ- 6 UNIOADE GEOTÉCNICA

P-STS SONOAGEM A PERCUSSĀO NE 515 nilimétricas de limonita ao longo do perfi

Fig. 9 - SEÇĀO GEOLÓGICO-GEOTÉCNICA REPRESENTATIVA dOS SEDIMENTOS ALUVIONARES E COLUVIONARES. 
representativos para a elaboração de seções longitudi nais de subsuperficie.

A anālise dessas seções (FIGURAS 8 e 9), confirina a existência de comportamentos geotēcnicos de subsuper fície diferentes para cada unidade geotēcnica homogênea. Entre as principais conclusões pode-se destacar:

a) diferenças morfolögicas (textura, cor, presença de concreções) entre as unidades geotēcnicas homogẽneas. Essas diferenças obviamente são mais marcantes quando se compara as unidades geotēcnicas representativas dos sedimentos aluvionares com aquelas dos sedimentos colu vionares. Por outro lado, observa-se uma homogeneidade muito grande entre os materiais encontrados numa mesma unidade geotēcnica;

b) nîtida relação de origem dos solos encontrados na unidade geotēcnica nọ 4 com äreas do terraço supe rior que sofreram processos de remanejamento por erosão seguida por deposição de areia lavada. Essa evidencia, observada com a elaboração da seção geológico-geotēcni ca (FIGURA 8) justifica a ocorrēncia das Areias Quartzo sas distróficas no terraço superior, cujo desenvolvimen to pedogenëtico foi abordado no item 3.4.2.;

c) a unidade geotécnica nọ 6, tanto em āreas de ocorrência dos sedimentos aluvionares, como em sedimen tos coluvionares, relaciona-se realmente $\bar{a}$ ocorrên cias de depressôes superficiais, estando no primeiro ca 
so associada a substrato sedimentar argiloso, e. no se gundo caso a presença em pequena profundidade do subs trato calcärio

d) os sedimentos aluvionares apresentam espessuras consideravelmente maiores que os sedimentos coluviona res. A profundidade mëdia dos depösitos aluvionares è de 20 metros, enquanto que dos depōsitos coluvionares $\bar{e}$ de 5 metros. Em vista disso, escavações realizadas nas unidades geotēcnicas distribuidas em sedimentos coluvio nares podem facilmente atingir material rochoso consti tuĩdo por calcārio;

e) tendo em vista as particularidades geolōgicogeotēcnicas mais importantes que podem interferir na construção do canal de adução, quais sejam, a resistēn cia à escavação, comportamento como fundação e estabilị dade de taludes, foi possivel distinguir quatro trechos característicos:

- trecho inicial representado pelas unidades geo tēcnicas homogēneas nọs 3 e 4 . Esse trecho apresenta co mo característica prinçipal a presença de uma camada re lativamente espessa de areia praticamente pura a pouco argilosa. Esse material, apesar de facilmente escavävel e de apresentar boas caracteristicas como fundação, compor ta-se de maneira instāvel como talude natural, tendo em vista suas caracteristicas de baixa coesão e consequen 
temente alta susceptibilidade a erosão;

- trechos representados peila unidade geotëcnica ho mogēnea nọ 5. Correspondem a sedimentos aluvionares bas tante ferralitizados e argilosos com espessuras superio res a seis metros, distribuidos sobre areia praticamen te pura ou argila de natureza aluvionar. 0 substrato calcārio encontra-se em profundidades relativamente ele vadas, superiores a 20 metros. Caracteriza-se portanto pela presença de materiais facilmente escaväveis; parte superior, até seis metros de profundidade, com comporta mento estāvel em taludes naturais, e instāvel em profun - didades superiores a seis metros, quando constituido por areia praticamente pura ou por argila aluvionar; apresenta bom comportamento como fundação, requerendo cuidados especiais apenas quando tratar-se da argila aluvionar, tendo em vista suas características de expan sividade e por permitirem recalques excessivos;

- trechos representados pela unidade geotécnica ho mogênea no 6 . Correspondem a sedimentos aluvionares e coluvionares excessivamente argilosos, contendo argilo minerais expansivos. Em se tratando de sedimentos colu vionares, o substrato calcārio encontra-se a pequenas profundidades, variando de 1 a 5 metros. Caracteriza-se portanto por apresentar cobertura sedimentar facilmente escavāvel, requerendo, entretanto, tratamentos espe ciais como taludes naturais e como material de fundação. 
Escavaçóes superiores a cinco metros podem encontrar ro chas cä"cárias, somente escavāveis com utilização de es plosivos. 


\section{CONSIDERAÇOES FINAIS}

A distribuição e tipologia dos solos, objetivo da Pedologia, constitui-se no mais sensivel parāmetro in dicativo das relações entre o substrato geológico e os agentes da dinâmica externa; os perfis pedológicos re fletem com bastante clareza tanto a contribuição das litologias subjacentes, como sua posição na encosta, alēm dos elementos climāticos e de vegetação. 0 solo, sendo o reflexo da interação do meio com os elementos da dināmica externa, estā portanto intimamente relacio nado com a paisagem, resultando de fundamental importān cia para a Geologia de Engenharia, o seu estudo dentro de um contexto mais amplo da paisagem, e não de maneira isolada.

A experiéncia de trabalho desenvólvida na região do Jaỉba, conforme apresentada nesta dissertação de mes trado, veio a confirmar essas evidencịas. Realmente, o mé todo de trabalho utilizado permitiu, com grande econo mia financeira e de tempo, interpretar o meio físico e compartimentar a região em unidades geotēcnicas homogê neas, destacando-se as características geotécnicas fun damentais para a orientação das investigações de campo e laboratōrio.

A sistemātica de trabatho adotada, mostrou-se de fundamental importância, principalmente nas fases in ciais de um projeto, onde o adequado conhecimento do 
meio físico intervem racionalmente nas investigações geológico-geotécnicas, destacando-se entre os princi pais resultados obtidos que substanciam essa afirmativa, os seguintes:

1. A interpretação geotécnica preliminar forneceu uma visão mais ampla da região em relação. às característi cas e fenômenos geotēcnicos, permitindo a delimitação em planta, de āreas com características geotëcnicas se melhantes. Esse trabalho, sendo realizado a partir de interpretação de dados existentes, fotointerpretação, e trabalho de campo a nivel de reconhecimento, foi con cluído em tempo relativamente curto, permitindo uma. atuação segura durante os trabalhos subsequentes.

2. Permitiu maior confiabilidade nas investigações geo Iógico-geotécnicas de subsuperfície. 0 zoneamento geo tēcnico preliminar forneceu critērios seguros de loca ção de sondagens mecânicas e poços de investigação. A descrição e caracterização dos perfis tornaram-se de fā cil conclusão, permitindo correlação segura com per fis vizinhos.

3. Permitiu grande economia em sondagens mecânicas. A locação de sondagens para investigação de subsuperfície ao longo dos canais principais e secundārios, $\bar{e}$ conven cionalmente realizada atravēs de critérios geomētricos 
com espaçamentos regulares entre sondagens. Esse critē rio, para a representação de seçñes geolōgico-geotēcnicas tecnicamente compativeis com as informações neces sārias, exige normalmente uma quantidade de sondagens muito grande.

Como exemplo ilustrativo, pode-se citar as investi gações de subsuperfície realizadas ao longo do canal principal nọ 2 do Projeto Jaĩba, com extensão de $32 \mathrm{~km}$. o critērio adotado para a locação de sondagens, com ba se no zoneamento geotēcnico preliminar, conduziu a um total de 50 sondagens a percussão e 100 sondagens a tra do. Caso fosse adotado o critērio geométrico para a lo cação de sondagens, pelo menos 100 sondagens a percur são e 500 sondagens a trado teriam sido realizadas.

4. Permitiu grande economia em ensaios de laboratório. Como exemplo, pode-se tambēm citar estudos realizados ao longo do canal principal no 2 do Projeto Jajba. A pesquisa de jazidas de materiais pará construção de aterros exige normalmente a realização de uma quantida de excessiva de ensajos geotécnicos de laboratōrio. Es ses ensaios são realizados em amostras coletadas numa malha de sondagens geometricamente espaçadas, junto ao corpo de aterro projetado. Tendo em vista que o canal principal ne 2 do Projeto Jaỉba foi totalmente concebi do em aterro, o estudo de jazidas com a adoção desse 
critērio, seria praticamente inviāvel. Procurou-se então, com basc no zoneamento geotécnico, direcionar a locação das jazidas ao longo do canal, minimizando substancial mente a quantidade de ensaios de laboratório.

5. Permitiu a previsão de comportamentos geotēcnicos e da necessidade de ensaios geotécnicos especiais, de interesse para o Projeto.

Dentro deste aspecto, salienta-se a constatação da existência na ārea estudada do fenōmeno de colapsivida de. Essa constatação foi despertada pela ocorrência de rupturas no terreno de fundação em um trecho de canal construído no inîcio da obra.

0 fenômeno de colapsividade estā provavelmente re lacionado ao estado de estruturação do solo, adquirido em função do desenvolvimento pedolögico do perfil. "As sim, Jennings (1957), estudando solos muito parecidos àqueles do Jä́ba, na Africa do Sul, procura explicar o fenōmeno por um arranjo estrutural no qual as particu las de areia estariam ligadas entre si atravēs de verda deiras pontes, formadas pelas partículas de silte e ar gilas, formando um conjunto de elevado indice de vazios e instāvel perante encharcamento, situação na qual esta estrutura se desmancharia dando origem a um novo arran jo mais compacto" (Wolle e outros, 1978).

A conceituação apresentada para o fenōmeno de co lapsividade sugere que a existēncia do fenōmeno esteja 
provavelmente relacionada ao prucesso pedogenētico de senvolvido sobre os sedimentcs a ?uvionares da Formação das Vazantes. Esse processo, onde se destaca o enrique cimento progressivo de argila e ferro do depósito alu vionar arenoso, permite que esses elementos se compor tem como verdadeiras "pontes" de ligação entre as partí culas de areia quartzosa, formando um arranjo estrutu rạ instāvel quando em contato com a àgua.

Neste sentido a interpretação geopedológica reali zada ē de fundamental importāncia para a orientaçäo dos ensaios de caracterização e quantificação do fenômeno de colapsividade, servindo de base para a sua programa ção.

outra particularidade geotēcnica diagnosticada a partir da interpretação geopedológica foi a ocorrēncia de argilas expansivas em determinadas unidades geotécni cas homogēneas. Trata-se das unidades geotēcnicas no 1 , 2 e 6 . Neste aspecto, os solos associados à unidade geo técnica no 6 mereceram atenção especial, por constitui rem-se em ocorrências possiveis de serem usadas como ma teriais de emprēstimo. Assim, para estes solos destacou -se a necessidade de realização, a diferentes profundi dades do perfil, de ensaios de expansividade, visando melhor conhecer o seu comportamento como materiais de "emprēstimo". 
6. Permitiu um planejamento seguro nas investigações pa ra materiais de aterro, com grande economia de tempo.

Tendo por base a interpretação geotēcnica prelimi nar, conforme descrita no item 4, foram programadas ao longo dos canais principais, sondagens a trado visando a coleta de amostras de solo para fins de caracteriza ção geotēcnica em laboratōrio. Foi possĩvel, dessa for ma, selecionar preliminarmente as zonas geotēcnicas ho mogêneas potencialmente favorāveis à ocorrência de ma teriais, geotecnicamente viāveis para utilização em aterro compactado.

Assim, foram selecionadas para estudos geotécnicos de Taboratōrio mais detalhados, apenas as zonas geotēc nicas distribuidas ao longo do terraço superior e do depōsito coluvionar. As demais äreas apresentam caracte risticas texturais e mineralōgicas desfavorāveis à com pactação em aterro.

o método utilizado, permitiu tambëm orientar a amostragem ao longo do perfil de sondagem, de maneira a se garantir a coleta de amostras com caracteristicas geotēcnicas diferentes. Assim, por exemplo, a zona geo tēcnica homogēnea nọ 4, distribuĩda no terraço supe rior, apresenta uma camada superficial de areia pratica mente pura com aproximadamente $1,5 \mathrm{~m}$, com caracteristi cas geotēcnicas desfavorāveis à compactação. Por outro lado, as äreas representadas pela zona geotécnica ho mogênea no 6 apresentam nas partes inferiores do perfil, 
concentração de argilas expansivas, cujo comportamento geotēcnico é desfavorável, quando utilizados em aterros compactados. 


\section{REFERENCIAS BIBLIOGRAFICAS}

AB'SABER, A.N. 1965. A evollção geomorfolōgica. In: A Baixada Santista, aspectos geogräficos. São Paulo, EDUSP. p.49-66.

AB'SABER, A.N. 1969. Uma revisão do quaternārio pau lista: do presente para o passado. Revista Brasilei ra de Geografia, Rio de Janeiro, 31(4): 1-51.

ATLAN, Y. \& FELLER, C. 1980. Aplication de la pedo logie a la caracterisation geotechnique de quelques sols fins du Senegal. Bulletin de l'association In ternationale de Géologie de l'ingēnieur, Paris, (22): 233-240.

BARROSO, J.A. e.t alii 1.281. Correlações de caracte rîsticas genëticas de solos e as suas propriedades geotëcnicas In: SIMPOSIO BRASILEIRO DE SOLOS TROPI CAIS em ENGENHARIA, Rio de Janeiro, 1981. Anais... Rio de Janeiro, COPPE/UFRJ, CNPq, ABMS, p.179-186.

BENVENUTO, C. et alii 1981. Estudo da colapsividade dos solos das fundações dos canais do projeto de ir rigação de Jaiba (MG). In: CONGRESSO BRASILEIRO de GEOLOGIA de ENGENHARIA, 3, Itapema/SC, 1981. Anais... São Paulo, ABGE. v.1, p.401-416. 
BIRKELAND, P.W. 1974. Pedology, Weathering, and geomorphological research. Boulder, Department of Geological Sciences, University of Colorado - 285p.

BUCKMAN, H.O. \& BRADY, N.C. 1976. Natureza e propriedades dos solos. Rio de Janeiro, Freitas Bastos.

BUNTING, B.T. 1971. . Geografia do solo. Rio de Janei ro, Zahar. 259p.

CAMARG0, F.P. 1976. Geologia de engenharia. Constru ção Pesada, 6 (61): 101-102, fev.

CARVAlHo, A. \& ROTTA, C.L. '1974. Estudo das forma çōes superficiais do municĩpio de Atibaia, São Pau 10. Boletim Paulista de Geografia, São Paulo, (49): 5-22.

CARVALHO, A. et alii. 1981. Caracterização mineralō gica e geotëcnica de alguns solos laterĩticos desen volvidos sobre basaltos na Bacia do Parană. In: SIM POSIO BRASILEIRO de SOLOS TROPICAIS em ENGENHARIA, Rio de Janeiro, 1981. Anais... Rio de Janeiro, COPPE/ UFRJ, CNPq, ARMS.. p. 340-381.

CHAUVEL, A. \& NOBREGA, M.T. 1980. Comportamento dos solos argilosos desenvolvidos sobre basaltos do Bra sil Meridional apös tratamento com cal. In: REUNIAO ABERTA da INDOSTRIA da CAL, 4, 1980. Boletim 12, p. $125-126$. 
DEERE, D.V. \& PATTON, F.D. 1971. Slope stability in residual soils. In: PANAMERICAN CONFERENCE on SOIL MECHANICS and FOUNDATION ENGINEERING, 4, Puerto Rico, 1971. Proceedings... New York, ASCE. v.1, p.87-170. i1.

DUCHAUFOUR, P. 1968. L'evolution des sols; essai sur la dinamique des profiles. Paris, Masson. $91 \mathrm{p}$.

DUCHAUfOUR, P. 1977 . Pedologie; pedogenēse et clas sification. Paris, Masson. v.l.

EMPRESA BRASILEIRA de PESQUISA AgROPECUARIA. Empresa. de Pesquisa Agropecuāria de Minas Gerais. 1976. Le vantamento de reconhecimento com detalhes dos solos do Distrito Agroindustrial de Jaiba, Minas Gerais, Belo Horizonte. (EMBRAPA/EPAMIG/RURALMINAS. Boletim Técnico, 54l.

ERHART, H. 1956. La genese des sols eytant que phë nomēne, gëologique; esquises d'une thëorie gëologi que et gēochimique, biostasie et rhesistasie. Paris, Masson. 90p. (Collection Evolution des Sciences).

FAUCK, R. 1972. Les sols rouges sur sables et sur grès d'Afrique Occidentale. Paris, ORSTOM. 257p. (Me mories, 61). 
FAURE, A. 1980. Comportamento mecänico das argilas em. função da sua natureza: formulação de uma nova con cepção de plasticidade e liquidez. In: REUNIAO ABER TA da INDUSTRIA da CAL, 4, 1980. Boletim 12, p.100123.

GRIM, R.E. 1953. Clay mineralogy. New York, McGrawHill. 384p. il.

HARDER, H. 1971, Quartz and clay mineral formation at surface temperature. Goltingen, Sediment Petro graphisches Institut du Universitat Gottingen.

INSTITUTO DE PESQUISAS TECNOLOGICAS DO ESTADO DE SAO PAULO. 1976. Estudos geolögico-geotécnicos para consolidação dos trechos ferroviärios Lages-Gal.Luz, Mafra-Lages e Mafra-Ponta Grossa. São Paulo, DMGA. (IPT Relatōrio nọ 8866).

INSTITUTO DE PESQUISAS TECNOLOGICAS DO ESTADO DE SAO PAULO . 1977. Reconhecimento geolögico de superfi cie de ärea de interesse à implantação do projeto de irrigação do Distrito Agro-Industrial de Jaĩba, Municĩpio de Manga, MG. São Paulo, DMGA. (IPT Relatō rio ne 10293).

INSTITUTO DE PESQUISAS TECNOLOGICAS DO ESTADO DE SÃO PAULO. 1979. Estudo de viabilidade tēcnico-econō mico de irrigação das microrregiões Sertão Alagoano e Batalha-AL. São Paulo, DMGA. (IPT Relatörion? 12333). 
INSTITUTO DE PESQUISAS TECNOLOGICAS DO ESTADO DE SAO PAUun. 1979. Estudos geolögico-geotécnicos da ärea de dominio do canal principal 2-30 000 ha do projeto Jaïba, Manga, MG. São Paulo, DMGA. (IPT Relatōrio no $12704)$.

INSTITUTO DE PESQUISAS TECNOLOGICAS DO ESTADO DE SAO PAULO. 1980. Revisão dos procedimentos adotados pela seção de Estradas em estudos de estabilidade de taludes. Projeto interno. São Paulo, DMGA (IPT Rela törio no 13215$)$.

INSTITUTO DE PESQUISAS TECNOLOGICAS DO ESTADO DE SAO PAULO. 1982. Estudos de pré-viabilidade para aprovei tamento dos recursos de água e de solos da região se mi-ärida do Estado de Sergipe. São Paülo, DMGA (IPT Relatōrio no 16138 ).

INSTITUTO DE PESQUISAS TECNOLOGICAS DO ESTADO DE SAO PAULO. 1982. Gēnese, distribuição e estratigrafiados depósitos cenozöicos do Estado de São Paulo, São Paulo. DMGA. (IPT Relatörio nọ 16 869.) 
JENNINGS, J.E. \& ROBERTSON, A.G. 1969. The stability of slopes cut into natural rock. In: ICSMFE, 7 th., México, 1969. Proceedings, v.2, p.585-590.

LEINZ, V. \& LEONARDOS, O.H. 1970, Glossārio geolögi co. São Paulo, Ed. Nacional/EDUSP. $236 \mathrm{p}$.

LOPES, F.0. 1977. Caracterização de latossolos verme Iho escuro no Norte de Minas Gerais. Viçosa. (Disser tação de mestrado (UFV).

MARCONI, A. \& ABRAHAO, I.0. 1976. Mineralogia e gra nulometria de três latossolos da região do mëdio Rio - São Francisco, BA. Anais da Escola Superior de Agri cultura Luiz de Queiroz, Piracicaba, 33: 415-428.

MELFI, A.J. \& PEDRO, G. 1977. Estudo geoquỉmico dos solos e formações superficiais do Brasil, parte 1 ca racterização dos principais tipos da evolução pedogeo quỉmico. Revista Brasileira de Geociēncia, 7: 271286.

MELFI, A.J. \& PEDRO, G. 1978. Estudo geoquímico dos solos e formações superficiais do Brasil; arte. 2 considerações sobre os mecanismos geoquímicos envol. vidos no Brasil. Revista Brasileira de Geociēncias, 8: $11-12$. 
MELFI, A.J. 1978. Natureza e origem das constituin tes secundārias dos solos desenvolvidos sobre as ro chas bāsicas da Bacia do Paranā. Cerâmica, 24 (105): 347-354.

MILNE, G. 1936. A provisional soil map of last Afri ca. s.1., s.c.p. (Amani Memoirs, 28).

MODENESI, M.C. 1980. Intemperismo e morfogēnese no Planalto de Campos do Jordão, SP. Revista Brasileira de Geocieñcia, São Paulo, 10 (3): 213-225.

MONIZ, A.C. 1972. Elementos de pedologia. São Paulo, Poligono/EDUSP. $459 p$.

NOGAMI, J.S. 1967. Os solos residuais do Estado de $\underline{\text { São Paulo, sua caracterização em bases geológicas pa }}$ ra finalidades rodoviärias. São Paulo. (Tese de Douto ramento apres.

NOGAMI, J.S. 1970. Classificação e terminologia para macroestruturação naturaf de solo's. In: SEMANA PAU LISTA DE GEOLOGIA APLICADA, 2, Säo Pau10, 1970.Anais... São Paulo, APGA. v.2, tema 2, p. 55-68. il.

NOGAMI, J.S. 1971. Iimportāncia da suplementação dos resultados geotēcnicos para finalidades rodoviāa rias, com dados geolögicos e correlatos. Rio de Ja neiro, Instituto de Pesquisas Rodoviārias. 47p. (IPR. Publicação 516l. 
NOGAMI, J.S. 1976. Necessidade de adequada caracter $\underline{i}$ zaçãi genētica de solos para finalidade rodoviäria. In: CONGRESSO BRASILEIRA de GEOLOGIA de ENGENHARIA, 1. Rio de Janeiro, 1976. Anais... Rio de Janeiro ABGE, v.1, tema, 1, p.19.26. il.

NOGAMI, J.S. 1980. Caracterização e classificação ge ral de solos para pavimentação: limitações do mētodo tradicional, apresentação de uma nova sistemätica. In: REUNIÃO ANUAL de PAVIMENTAÇAO, 15, Belo Horizonte, 1980. Atas... Belo Horizonte.

NOGAMI, J.S. \& VILLIBOR, D.F. 1981. Uma nova classi ficação de solos para finalidades rodoviärias. In: SIMPOSIO BRASILEIRO de SOLOS TROPICAIS Em ENGENHARIA, Rio de Janeiro, 1981. Anais... Rio de Janeiro COPPE/ UFRJ, CNPq, ABMS. ABMS. p. 30-41.

OLIVEIRA, A.M.S. 1981. Estudo da percolação d'ägua em macicos rochosos para o projeto de grandes barra gens. São Paulo. 197p. (Dissertação de metrado. Ins tituto de Geociēncias. USPL.

ORGANIZACION de Ias NACIONES UNIDAS para Ia AGRICULTURA y la ALIMENTACION. 1971. Mapa mundial de suelos I:5000 000. Paris, UNESCO-FAO. v. 4 .

PAQUET, H. 1970. Evolution gēochimique des minēraux argileuse dans les altērations et les sols des climats mediterranēens tropicaux $\bar{a}$ saisons counstrastēes. 
Strausbourg, Universite Louis Pasteur, Institut de Geōlogie. 212p. (Mëmoires du service de la Carte Geologique d'Alsace et de Lorraine., 54).

PEDRO, G. 1966. Essais sur la caracterisation geochj mique des differents processes zonaux rēsultant de l'altëration des roches superficielles. C.R.Ac.SC., Paris, (2920). 1828-1831.

PEDRO, G. 1980. Papel e influência das característị cas mineralógicas sobre as modalidades de organiza ção dos materiais argilosos nas condições de meio su perficial. In: REUNIAO ABERTA da INDUSTRIA da Cal, 4, São Paulo, 1980. Boletim, São Paulo, ABPC, (2): 1459.

PONÇANO, W.L. et alii, 1979. O conceito de sistemas de relevo aplicado ao mapeamento geomorfológico do Estado de São Paulo. São Paulo, IPT. 10p. (IPT.Publi cação interna).

POUQUET, J. 1966. Les sols et la geographie; initiation gēopedologique. Paris, Place de la sorbonne. $266 \mathrm{p}$. (Sociēë d'Edition d'Enseignement supërieur, 5).

PRINCIPI, P. 1964. Geopedology; studio dei terreni naturali ed agrari. Roma, Ramo Ed. Degli Agricoltori. $578 p$. 
QUEIROZ NETO, J.P. de 1974 . Solos e pedossolos do ES tado de São Paulo e suas interpretações paleogeogrā ficas. In: CONGRESSO BRASILEIRO de GEOLOGIA, Porto Alegre, 1974. Anais... Porto Alegre, SBG. v.3, p.17픈 181.

QUEIROZ NETO, J.P. de \& JOURNAUX, A. 1978. Carta do modelado e das formações superficiais do mëdio Vale do Rio Parateî, SP. São Paulo, IGEOG/USP. 34p. il. (Sedimentologia e Pedologia, 9).

QUEIROZ NETO, J.P. \& MODENESI, M.C: 1973. Observações preliminares sobre as relações entre os solos e a geomorfologia na ärea de Itü. São Paulo, IGEOG/USP. 28 p.il. (Sedimentologia e Pedologia, 3).

QUEIROZ NETO, J.P. de et alii. 1973. Cronologia da al teração dos solos da região de Marillia, SP. São Pau 10, IGEOG/USP. 52p. il. (Sedimentologia e Pedologia, $5)$.

RANZANI, G. et alii. 1972. Concreçōes ferruginosas, pa leosolo e a superficie de cimeira no Planalto Ociden tal Paulista. São Paulo, IGEOG/USP. 28p. i1. Geomorfologia, 31).

RODRIGUES e SILVA, F.B.R. 1982. Alteração de rochas do Grupo Bambuĩ, solos e processos pedogenéticos.s.L. (Seminärios gerais, mimeografado). 
SAAD, A.M. et alii. 1978. Coiltribuiçăo dos estudos geolōgico-geotēcnicos pará iliplantação do projeto de irrigação do distrito agroindustrial de Jaíba, Muni. cĩpio de Manga, MG. In: CONGRESSO BRASILEIRO de GEO LOGIA de ENGENHARIA, 2, São Paulo, 1978. Anais...são Paulo, ABGE. v.2, p.111-124.

SALOMAO, F.X. de T. et alii. 1981. O estudo do meio físico como subsỉdio para a identificação de āreas potencialmente irrigäveis. In: CONGRESSO BRASILEIRO de GEOLOGIA de ENGENHARIA, 3, ...tapema/SC,..1981. Anais... São Pau1o, ABGE. v.1, p.285-299.

SANEJOUAND, R. 1972. La cartographie gēotechinique em France. Paris, Min. Equip. Logem. Dir.Amër. Fonc.Urban. A.R.M.I.N.E.S.L.C.P.C. 96 p.

SANTOS, A.R. 1976, Por menos ensajos e instrumenta ção e por uma maior observação da natureza. In: CON GRESSO BRASILEIRO de GOLOGIA de ENGENHARIA, 1. Rio de Janeiro, 1976. Anais... Rio de Janeiro, ABGE. v. T, p. 177-186.

SANTOS, M.T.N. dos et alii. 1981. Utilização da pedolo gia em um estudo geolōgico-geotēcnico para implanta ção do projeto de irrigação do distrito agroindus trial do Jaỉba. In: CONGRESSO BRASILEIRO de GEOLOGIA de ENGENHARIA, 3, Itapema/SC, 1981. Anais.... São Pau 10, ABGE. V.1, p.401-416. 
SERVIÇO NACIONAL DE PESQUISAS AGRONÖMICAS. Comissão de Solos. 1960. Levantamento de reconhecimento dos so los do Estado de São Paulo; contribuição à carta de solos do Brasil. Rio de janeiro. 634p. (SNPA/CS. Bo letim 12)。

SETZER, J. 1949. Os solos do Estado de São Paulo. Rio de Janeiro, IBGE.

TESSIER, D. 1980. Papel e influēncia das condições fỉsico-quỉmicas do meio sobre o comportamento hïdri co e a organização dos materiais argilosos. In: REU NIAO ABERTA da INDOSTRIA da CAL, 4, São Pau10, 1980. Boletim, São Pauto, ABPC, (12): 60-99.

TOGNON, A.A. et alii. 1976. Metodologia para caracte rização geotēcnica de maciços basālticos em Tūneis viārios. In: CONGRESSO BRASILEIRO de GEOLIGA de ENGE NHARIA, 1, Rio de Janeiro, 1976. Anais... Rio de Ją neiro, ABGE, v.2, p.453-467.

TRICART, J. 1965. Principes et Methodes de 1a geomorphologie. Paris, Masson. 496p.

VARGAS, M. 1974. Mecânica dos solos. São Pau10, EPUSP $203 p$.

WOLLE, C.M. 1980. Taludes naturais; mecanismos de instabilização e critêrios de segurança. São Paulo. (Dissertação de mestrado. Escola Politēcnica/USP). 
WOLLE, C.M. et alii. 1978. Estudo preliminar da colap sividade dos solos no projetc Jaĩba, MG. In: CONGRE SO BRASILEIRO de GEOLOGIA de ENGENHARIA, 2, São Pau 10, 1978. Anais... São Paulo, ABGE. v.1, p.179-194. 